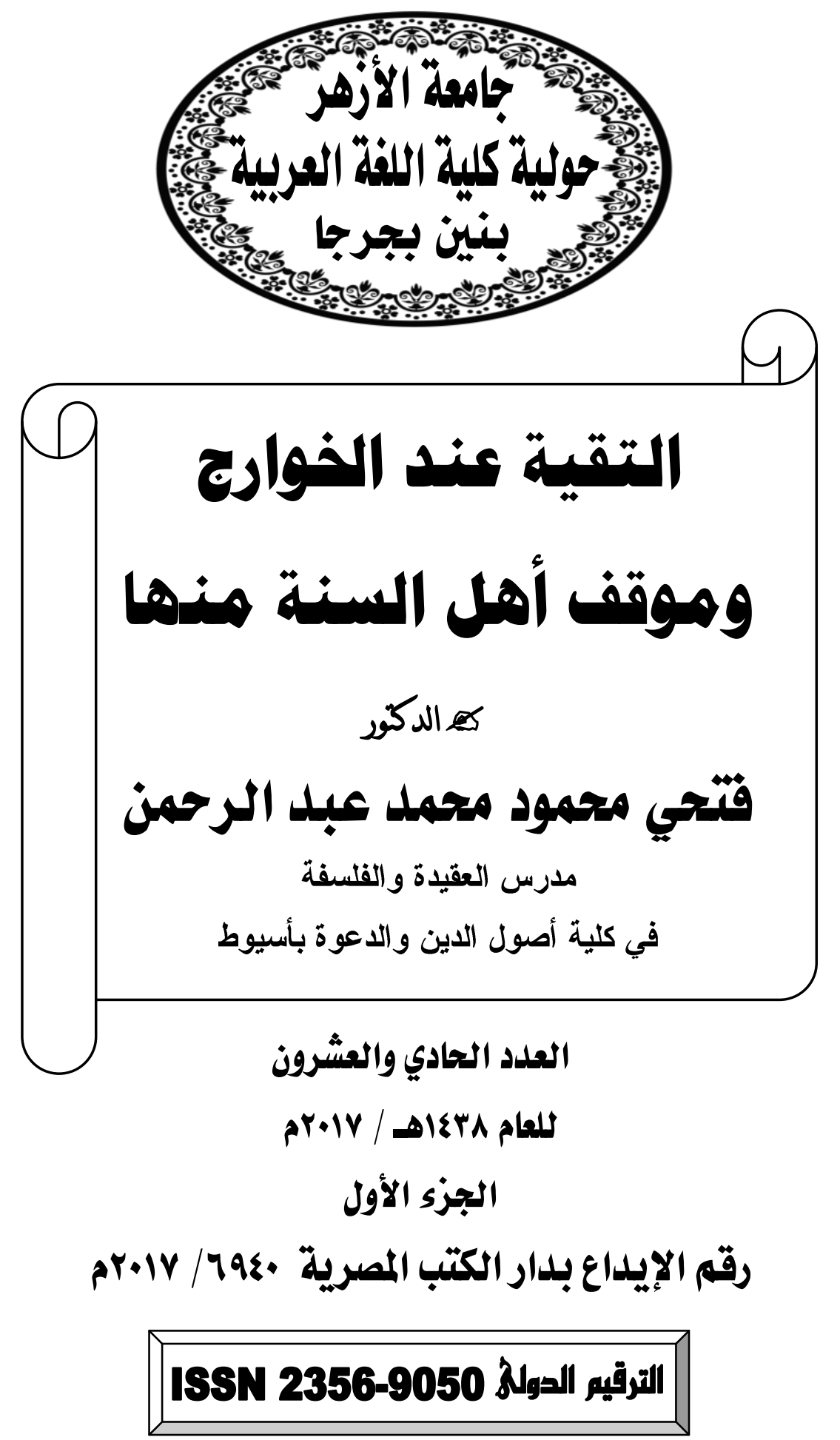




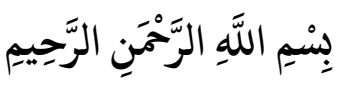 \\ المقدهة}

الحمد لله الواحد الأحد، الفرد الصمد، الأى لم يلا ولم يولد ولم يكن له

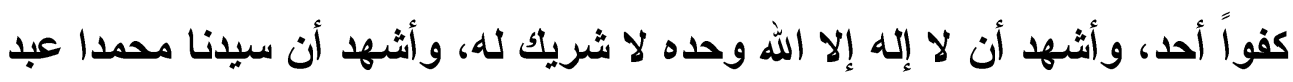

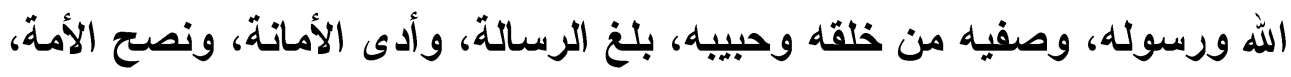

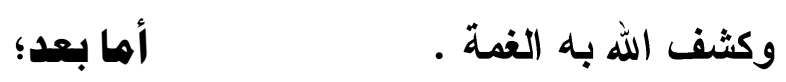

فإنّ نشر مفاهيم الإسلام، ومحاولة تصحيح النظر إلى بعضها عبر وسائل

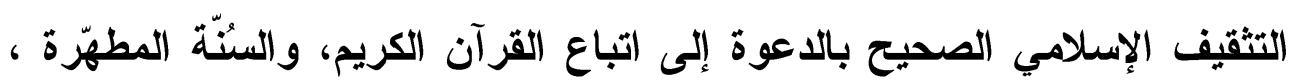
يتطلب معرفة تلك المفاهيم وموقف الاين الإسلامي منها، ووضعها في مكانها الصحيح بعد تشخيص موقعها من الفكر الايني، وعمق تاريخها فيه، وعلاقتها

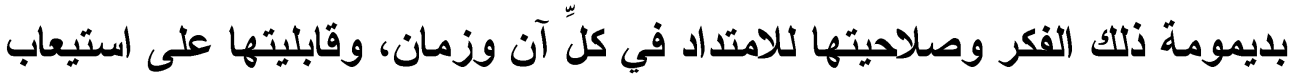

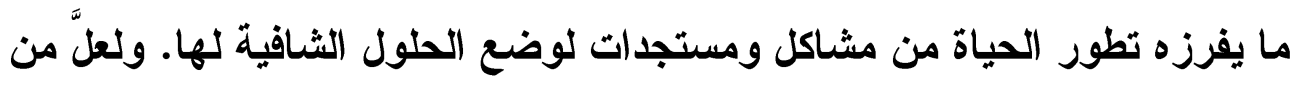
بين تلك المفاهيم التي نطق بها القرآن الكريم والسيّنة المطهرّة هو مفهوم التقية الأي لم ينحصر في الواقع بلين الإسلام؛ بل عرفته الأديان السماوية كلّها،

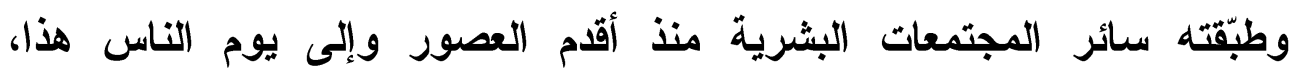
لاسجبامه التام مع مقتضى العقول وفظرة الإنسان في الحفاظ على كيانه . ولذلك كان دفاع الإسلام قرآناً وسنّنة في تبنيه وإمضائه وتأييده لهذا المفهوم، إنما هو في الواقع دفاع عن الفطرة والعقل السليم. فالتقية قاعدة عقلية جبلت عليها العقول السليمة، فحكمت بضرورة تجنب الضرر شخصياً كان أو نوعياً، ومن هنا أصبح موقف الإسلام من التقية موقف

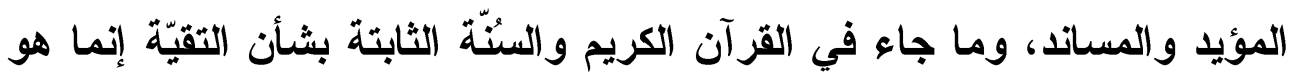
إمضاء لها لأنها من شرع ما قبلنا كما يفهم من تقية إبراهيم ويوسف عليهما السلام، ومن تقية أصحاب الكهف ومؤمن آل فرعون.

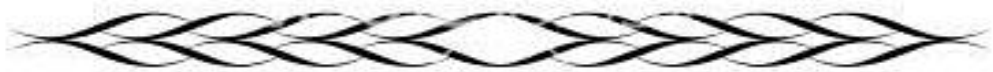




\section{أهداف الدراسة}

تهرف الارسة إلىى تحقيق جملة من الأهداف التالبة: ا. التعرف على المفاهيم المتعلقة بالتقية.

r. إيضاح حكم التقية في الثريعة الإسلامية.

r. إيضاح آثار وسبل معالجة الآحرافات الفكرية. ومقاومة ومحاربة ذلك

الانحر اف الفكري الخطير.

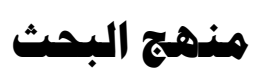

وقد استخدمت في هذا البحث المنهج التحليلي القائم على تحليل محتويات النصوص واستخر اج المنى منها، وإبرازه في صورة مبسطة، وصياغتها بصيغة

موضوعية

وقد اقتضت طبيعة هذا البحث أن يأتي في: مقدمة، وثلاثة مباحث، ثم

خاتمة، وفهرس للمصادر و المر اجع •

أما الاقدهة: فقد اثتملت على أهمية الموضوع، والهدف من الاراسة، ومنهج البحث وخطة البحث .

وأما المباحث فقد جاعت مرتبة على النحو التالي: المبحث الأول: التعريف بالمصطلحاث الواردة في عنوان البحث. المبحث الثاني: أراء وأفكار الخوارج في التقية. المبحث الثالث: موقف أهل السنة واراهم في التقية. الخاتمة: وقد اشتملت على أهم نتائج البحث. ونسأل الله أن ينفعنا بما علمنا وأن يعلمنا ما ينفعنا إنه ولى ذلك والقادر عليه وهو الهادي إلى سواء السبيل . 


\section{المبحث الأول}

التعريف بالاصطات الهاردة في عنوان البحث

التقية ـ الخهارج ـ أهل السنة

أولا: هفهوم التقية في اللاغة والاصطلاح:

1اتقبية في الغنة:

التقية بفتح التاء وتثديدها، وكسر القاف، وفتح الياء وتثديلها ــ تطلق في اللغة عدة اطلاقات، منها: الخوف، والحذر، والكتمان.

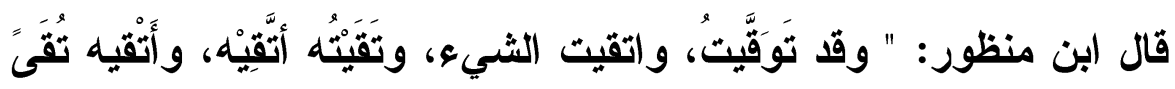

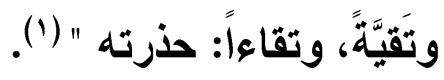

وقال: " التقية والتقاة بمعنى، يريد أنهم يتقون بعضهم بعضاً، ويظهرون

الصلح و الاتفاق، وباطنهم بخلاف ذلك " (ץ).

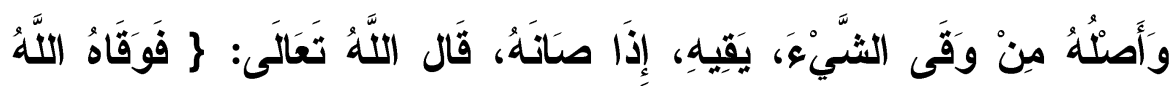

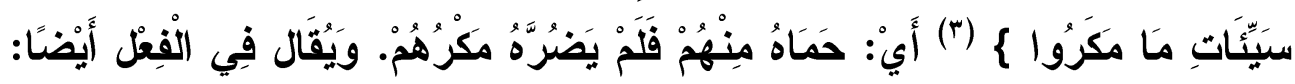

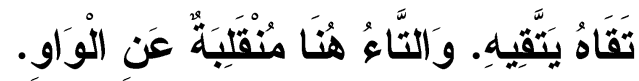

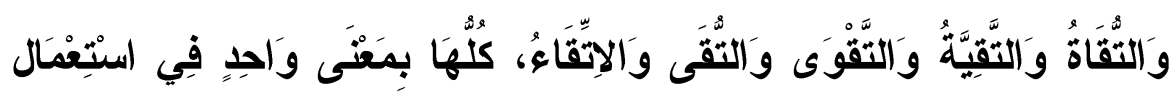

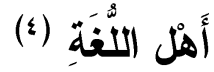

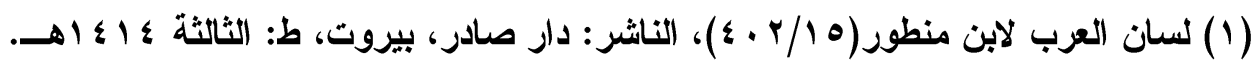

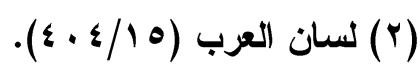

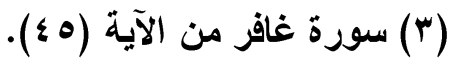

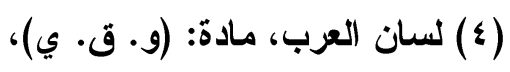




\section{النققية في الاصطلام:}

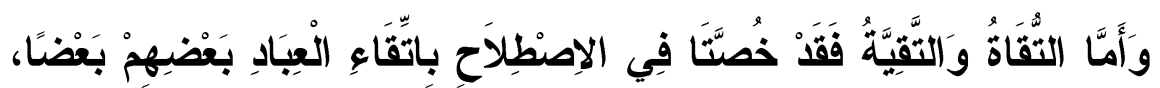

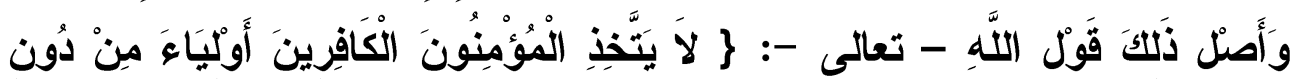

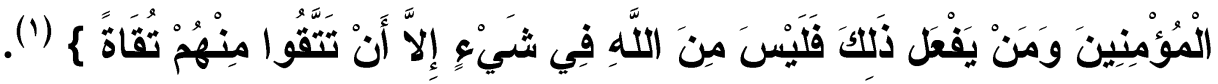

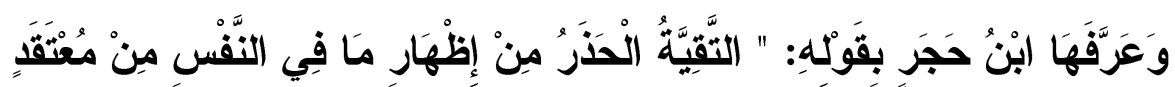

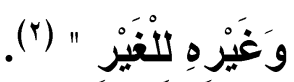

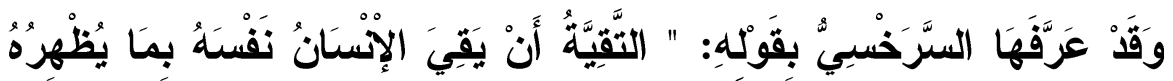

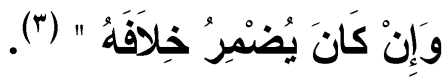

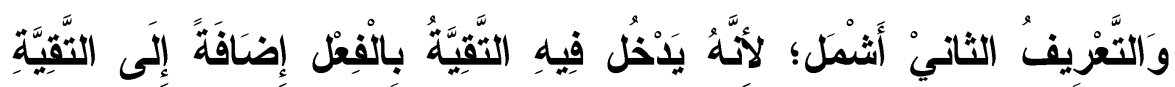

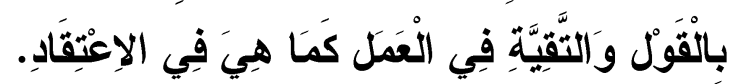

وعرفها حبر الأمة عبدالله بن عباس - ب- فيما روي عنه أنه قال:

"التقاة: التكلم باللسان وقلبه مطمئن بالإيمان "(๕).

$$
\text { (1) سورة آل عمران من الآية (r^). }
$$

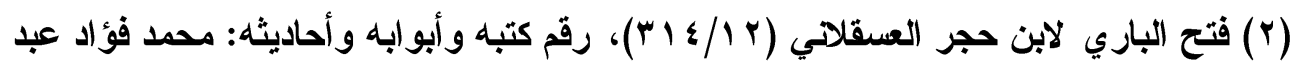

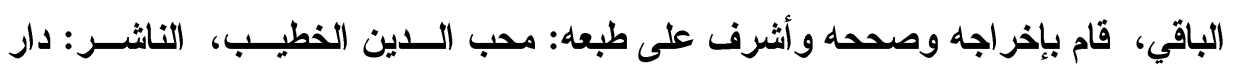

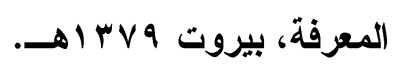

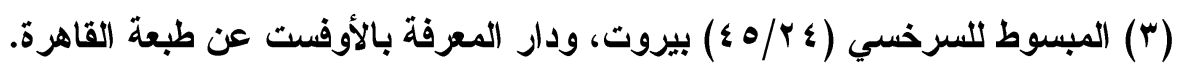

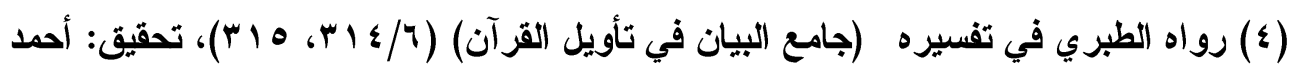

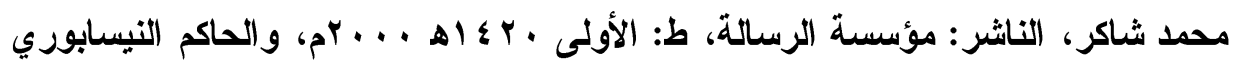

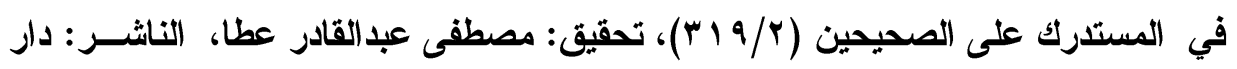

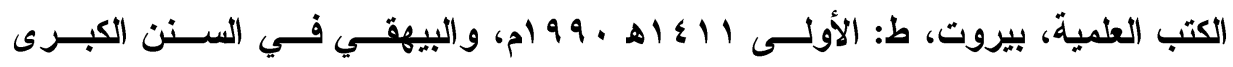

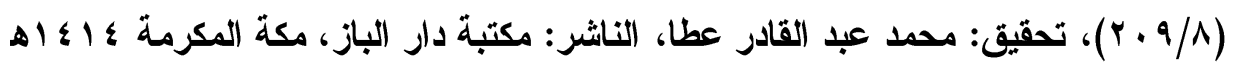

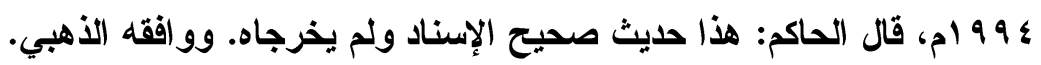




\section{د. فتحي محمود محمد عبد الرحمن}

की $1 \varepsilon 0$

التقية

عند الخوارج وموقف أهل السنة منها

قال الضحاك: التقية أن يحمل على أمر يتكلم به بلسانه من معصية الله فيفعل وهو مطمئن بالإيمان، فلا إثم عليه.

فالتقية من الاتقاء، وهي الاستخفاء بالإسلام لعذر يبيح ذلك، سواء كان ذلك بكتمان الاين وعدم إظهاره، أو بإظهار ما يخالف الإيمان من كفر أو معصبة) (1) - (1)

وبذلك يتضح أن التقية أن يتكلم الإسان بلسانه وقلبه مطمئن بالإيمان وبذلك يقي نفسه من العقوبة، وإن كان يضمر خلافه ويحافظ على النفس والمال من شرّ الأعداء فيتقيهم الإسسان بإظهار الموالاة من غير اعتقادٍ لها.

\section{القراءات الواردة في النقبية:}

عن المنذري عن أحمد بن يحيى أنه قال في قوله:جر إلَّاَ أَنْ تَتَّقوا مِنْهُمْ

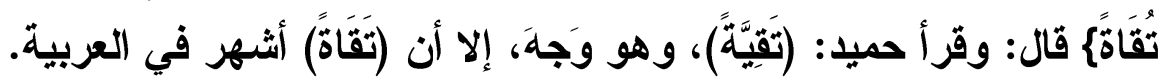

قال: وسمعت ابن الأعرابي يَقُول: واحُِّ التقَي: تُقَاةَ، ومثثله: طلاة وطلىً، وأنشد قول الأعشى: - مئ:

متى تُشْقَ من أَنْيابِها بعد هَجْعِةٍ

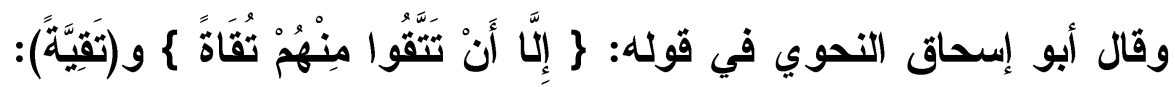
قُرُئَا جميعا.

وقال الفراء: ذكر عن الحسن ومجاهد أنهما قرعم: (تَقَيَّةً) (؟).

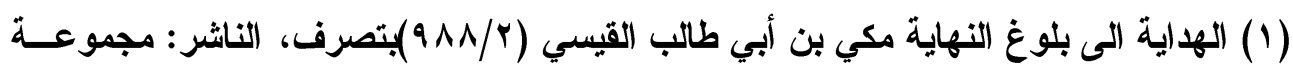

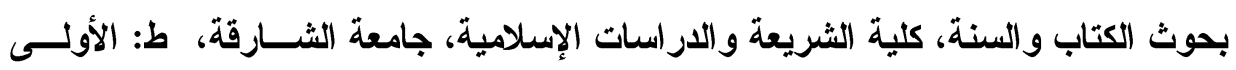

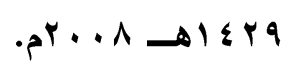

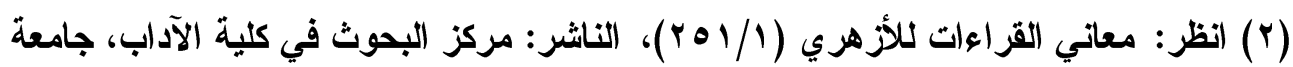

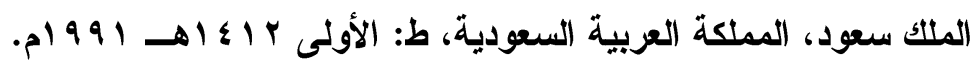




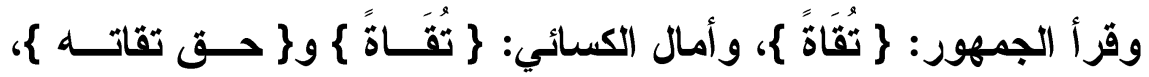

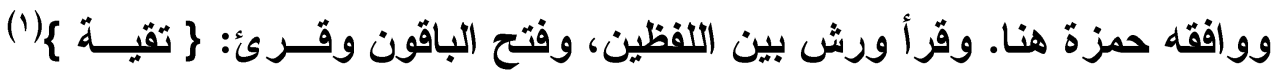
\}تقَّةًاة : مصدر على وزن فعلة؛ لأنه مصدر تقَيته - بفتح القاف - كرميته رمية، وأصله: وقية؛ لأنه من الوقاية، فأبدلت الواو تاء، والياء ألفًا؛ لتحركها وانفتاح ما

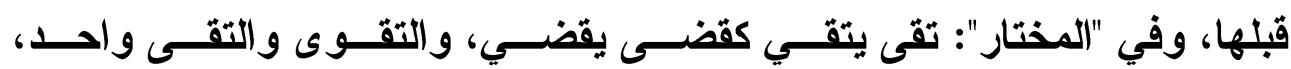
والتقاة: التقية يقال: اتقى تقية وتقاة، وفي "القاموس": وتقيث الثيع أتقيه مسـن

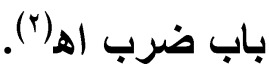
وقال أبو حيان: والمصدر على فُعَّة جاء قليلاً ولو جاء على المقيس لكان

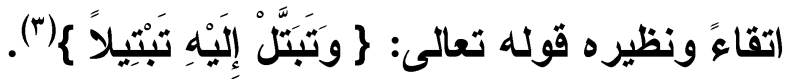
والمعنى: إلا أن تخاقوا منهم خوفاً فلا بأس بإظهار مودتهم باللسان تقية

ومدار اة دفعاً لشرهم وأذاهم من غير اعتقاد بالقلب(أ).

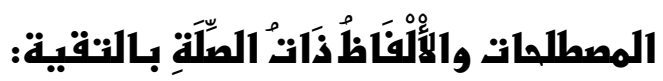
هناتك عدة مصطلحات ذَاتُ صِّلَةِ بالتقية، ولكن عند دراستها وجددت فروق بينها من هذه المصطتحات :

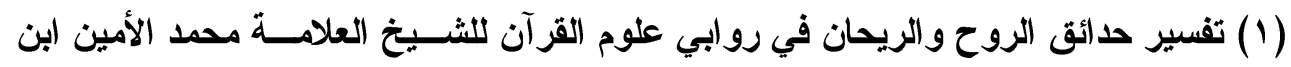

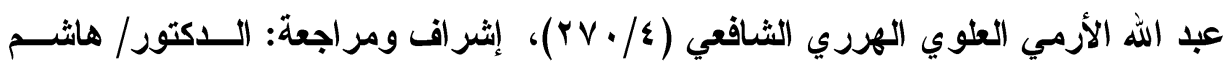

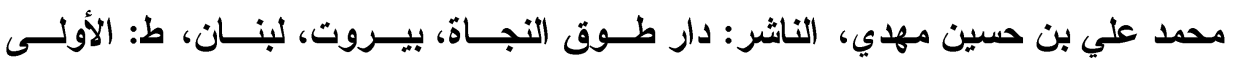

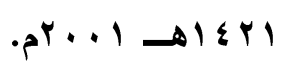

(r) (المرجع السابق نفس الصفحة.

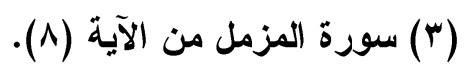

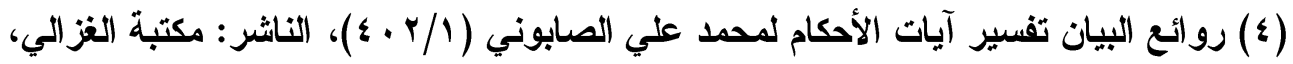

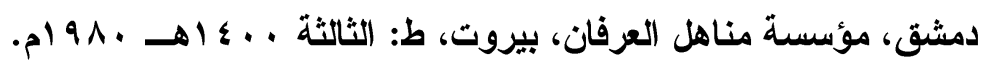




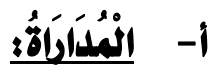

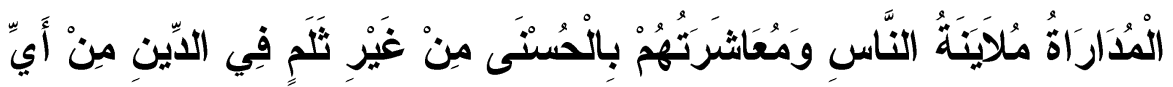

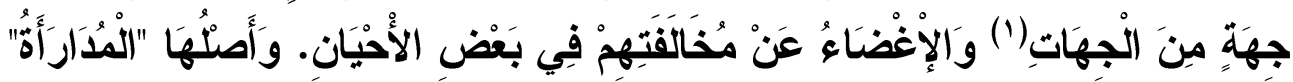

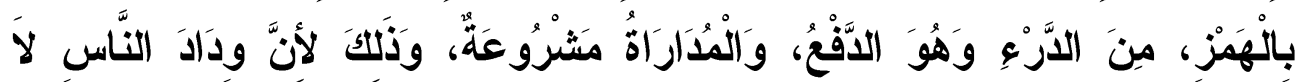

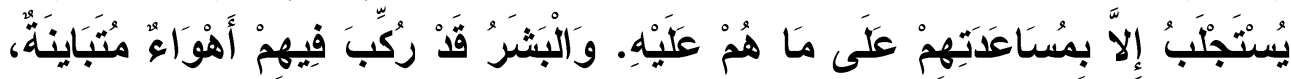

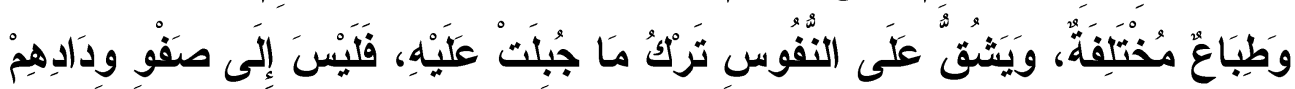

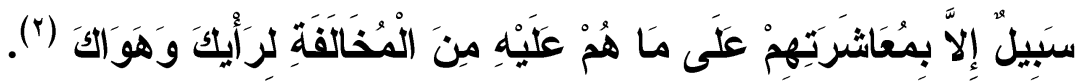

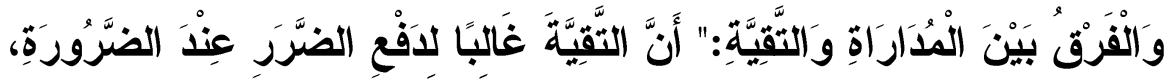

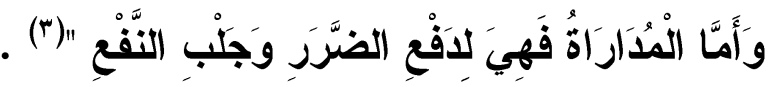

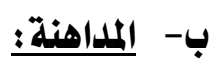

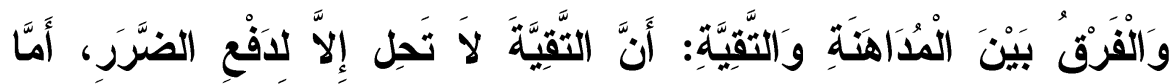

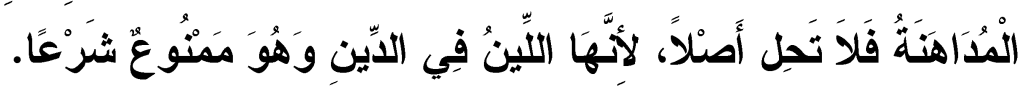

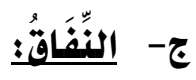

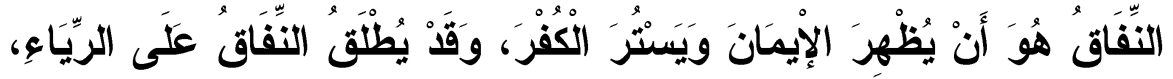

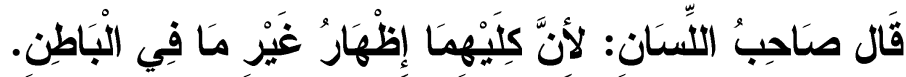

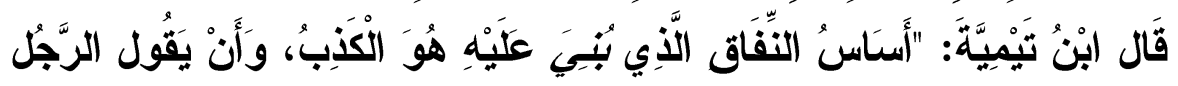

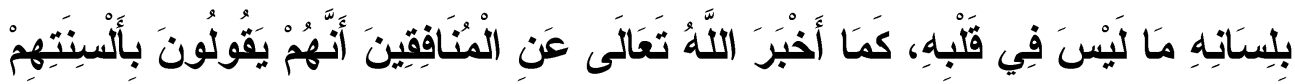

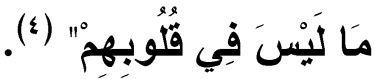

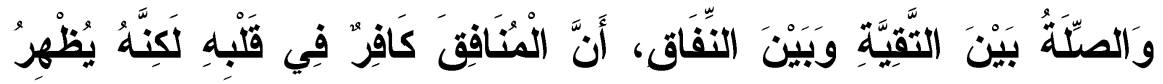

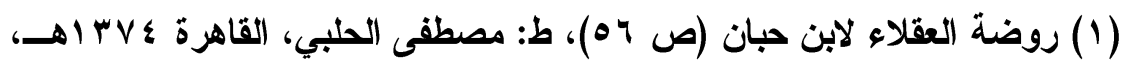

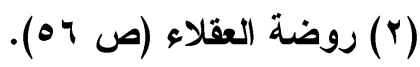

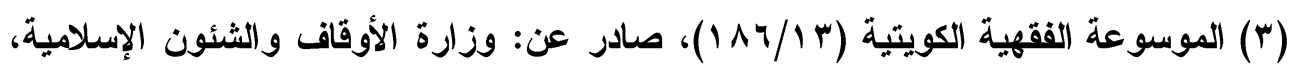

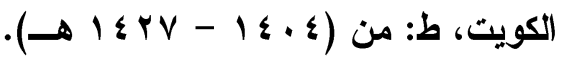

$$
\begin{aligned}
& \text { () المصدر السابق نفس الصفحة. }
\end{aligned}
$$




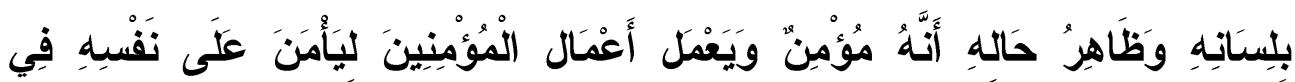

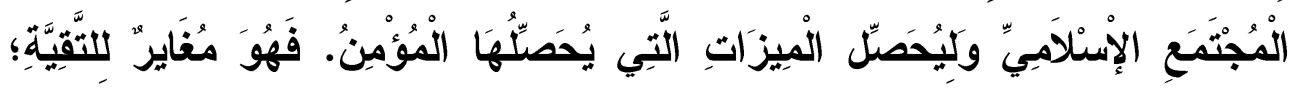

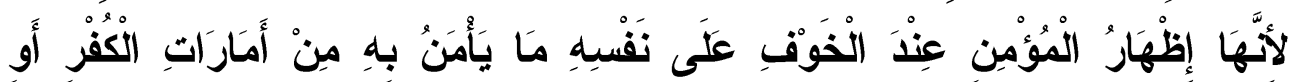

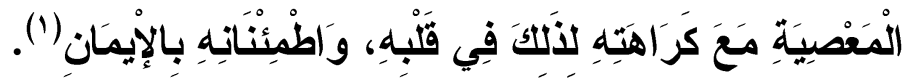
د- التقية والاكراه:

اختلف أهل العلم في تحديد معنى الإكراه، كما اختلفوا في مقدار ما يباح

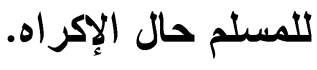

أصل الاكراه لغةةً:

مأخوذ من الفعل (كَرَهَ)، والاسم: (الكَرَهُ) ويراد به كل ما أكرهك غيرك

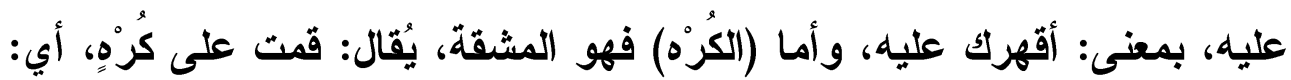
على مشقة.

و الفرق بين (الكَرْهِ)، و (الكُرْهِ) أن الأول هو فعل المضطر، بينما الثاني

هو فعل المختار (r). وأَّاً في الاصطلمة:

فقا عرقهه التقتازاني بأنه: " حمل الغير على أن يفعل ما لا يرضاه، ولا

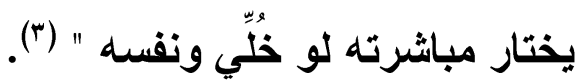

وفي تعريف الإكراه يقول ابن حجر: " هو إلزام الغير بما لا يريده " (؛).

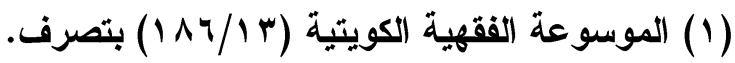

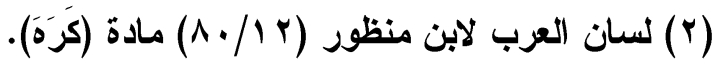

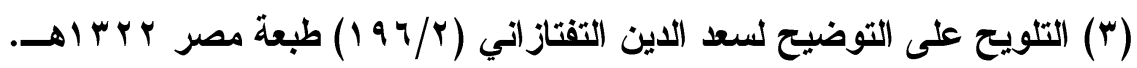
(ع) فتح الباري (1/ (1) (1). 


\section{د. فتحي محمود محمد عبد الرحمن}

كما عرّقه عبدالعزيز البخاري الحنفي بقوله، هو: " حمل الغير على أمرٍ

يمتنع عنه بتخويف يقدر الحامل على إيقاعه، ويصير الغير خائفاً به " ('). ولعلّ أوجز تعريف للإكراه هو ما نجده عند الثيخ الأنصاري - I - إذ إذئ

عرّف الإكراه بأتّه: " حمل الغير على ما يكرهه " (؟). أنواع الإكراه:

الإكر اه في جميع صوره على نوعين، وهما:

\section{النوع الأول : الإكراه على الكلام المخالف للحق.}

وهذا النوع لا يجب به شيء، فكل ما أكرِه عليه المسلم فله ذلك وله أمثلة كثيرة جداً، أثثدها: التلفظ بكلمة الكفر، وهنا يجب الالتفات إلى نقطة في

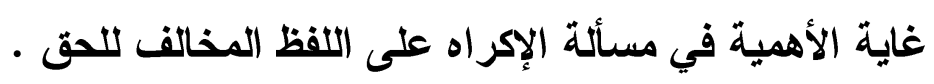
ونعني بها صلة الألفاظ بأفعال القلوب التي لا سبيل للمكرِه إلى عملها في قلب المكره، وعليه فلا يصح التجاء المكره إلى شيء منها قط، كما لو أُكره على بلى كلمة الكفر، أو على الاعتقاد بعقيدة فاسدة، أو إنكار كل ما ثبت أنه من الدين إنكار اً قلبياً لا لفظياً. فمثل هذه الأمور ونظائر ها يجب الاحتراز فيها جداً، بحيث لا يتعدى النطق باللفظ إليها، لأنها ممالا يصح فيه الإكر اه. فغاية الأمر: إن المكرَه يريد التخلص من الثر بإتيان اللفظ المخالف للحق، لا أن يُؤمِن بما يتلفظ به حقيقة.

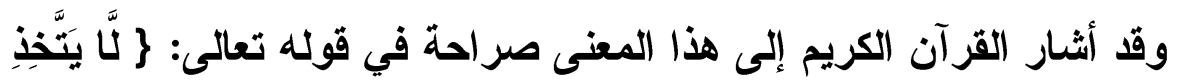

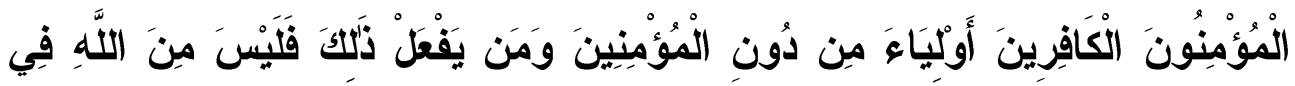

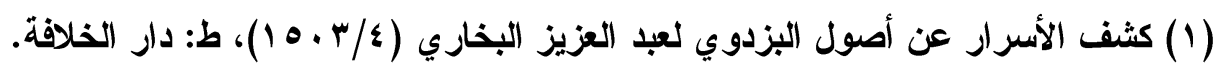

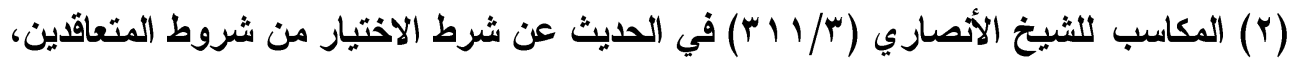

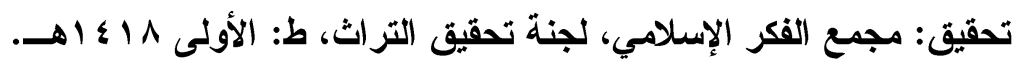




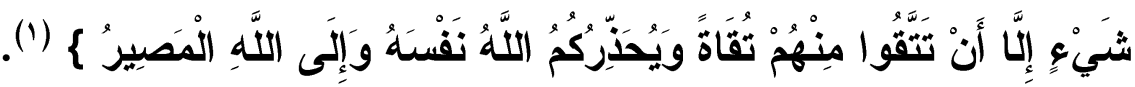
ومما يلحظ هنا هو أن التحذير الثديد الوارد في الآية المباركة قد جاء مباشرة بعد تشريع التقيّة في الآية نفسها، ثم أكده تعالى بقوله الكريم: \} قُلْ إنِ

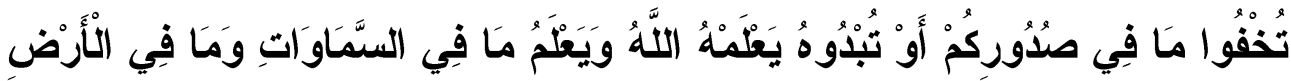

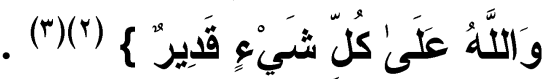
وكل هذا التحذير قد جاء في سياق واحد بعد تشريع التقيّة، لئلا يتحول إنكار المؤمن للحق بفعل الإكراه إلى إنكار قلبي كما يريده من أكرَهه؛ لأنّ الواجب أنْ يبقى القلب مطمئناً بالإيمان.

\section{النوع الثاذي : الإكراه على الفعل المحظور:}

لا شكَّ أنّ الثريعة لم تبح جميع الأفعال المحظورة بلا قيد أو شرط، لأنَّ

الأفعال المحرمة في نظر الشريعة الغراء على نحوين: أحدهما: "تسوغ معه التقيّة حال الإكراه عليه، وأمثلته كثيرة كالتقيّة في السرقة، أو اتلاف مال الغير، أو الإفطار في شهر رمضان، أو تأخير الصلاة، أو الامتناع عنها إذا اقتضى الإكراه ذلك أو شرب الخمر على خلاف فيه، ونحوها من الإن الأمور التي يجوز ارتكابها عند الإكراه عليها. والآخر: لا تسوغ معه التقيّة مطلقاً وفي جميع الأحوال مهما بلغت درجة الآدة

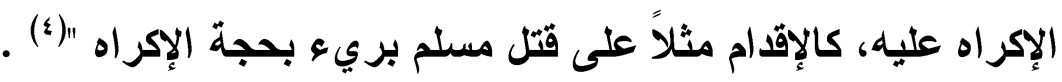

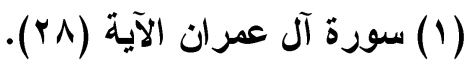

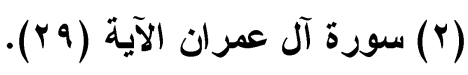

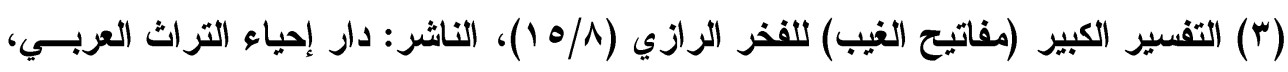

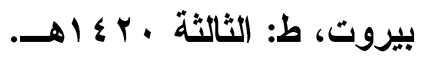

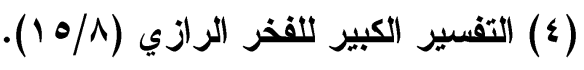




\section{د. فتحي محمود محمد عبد الرحمز}

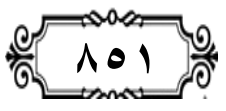

التقية

عند الخوارج وموقف أهل السنة منها

ومن كل ما تقدم يعلم اتفاق الفريقين على كون الإكراه حالة من حالات

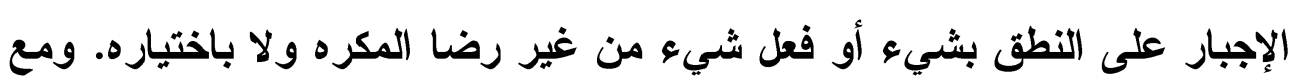
هذا فقد لا يتحقق الإكراه في الواقع وإن توفرت بعض مقوماتهئه.

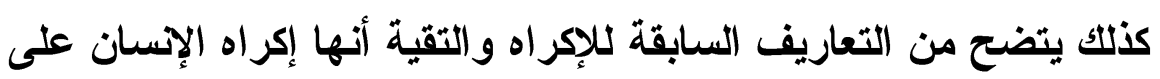
الإتيان بشيء مخالف للحق يكون سبباً مباشراً من أسباب حصول التقيّة، ويؤيّده ما جاء في قصة عمار بن ياسر(1) وجماعته الأين اتقوا من المشركين فأجروا

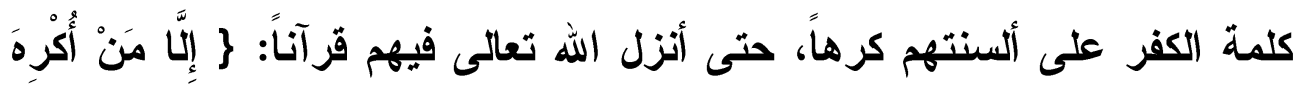

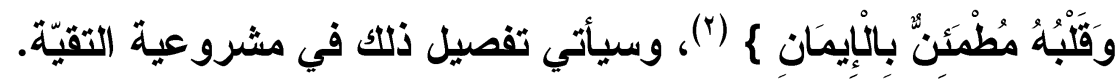
ولكن يبدو واضحاً من خلال مراجعة موارد التقيّة في فقة المذاهب مئه

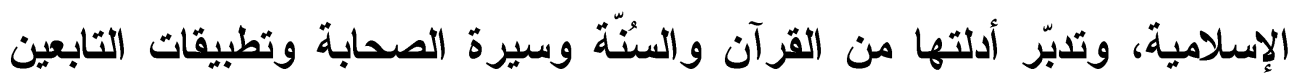
وغيرهم من المسلمين أنه لا حصر للتقية على كتمان الحق وإظهار خلافه خوفاً على النفس من اللائمة والعقوبة بالإكر اه، لاخول ما إذا كان هذا الكتمان لمصالح

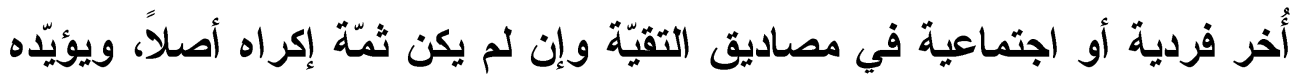

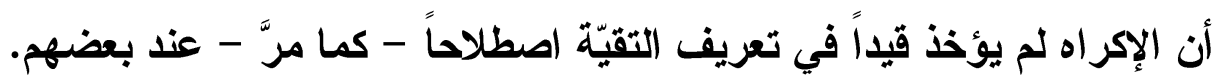

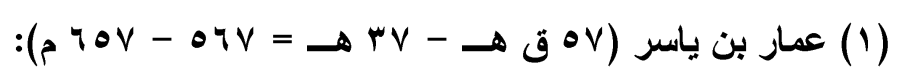

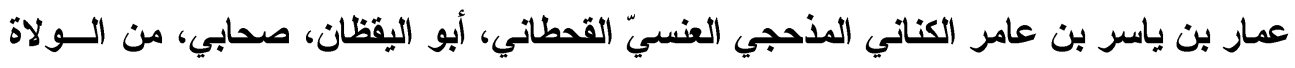

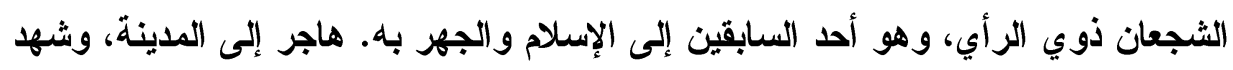

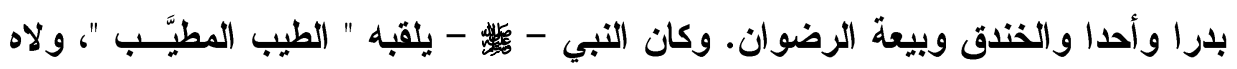

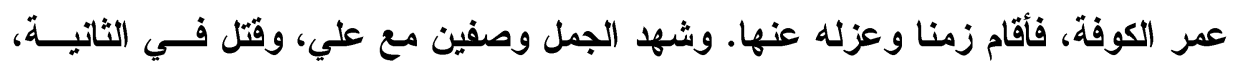

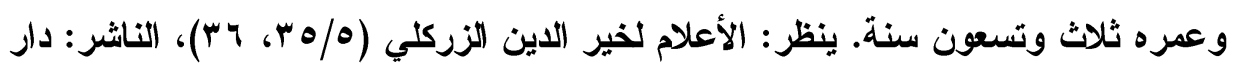

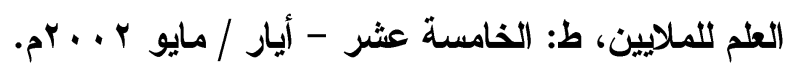

(ץ) سورة النحل من الآية (ף • (1). 


\section{وفي ببان الملة بين النقةية والإكراه:}

يقول ابن العربي: " والإكراه المبيــح لذلك هو أن يخاف على نفســه

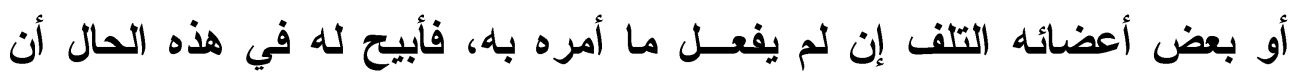

يظهر كلمة الكفر " (1).

ونقل ابن بطّل الإجماع على جواز التقية من القتل بالكفر، فقال: " أجمعوا على أنّ من أكره على الكفر حتّ خثي على نفسه القتل فكفر وقّلبه مطمئنّ بالإيمان أنّه لا يحكم عليه بالكفر ولا تبين منه زوجته .. " " (؟). ولئن اتفق العلماء على جواز التقية في الأقوال، فإنهم اختلفوا في جوازها في الأفعال، والراجع أن الإكراه يبيح تقية القول والفعل على السواء، إلا في قتل النفس المعصومة، فإنه لا يجوز قتلها تقية بالإجماع. قال ابن حجر: " ولا فرق بين الإكراه على القول والفعل عند الجمهور،

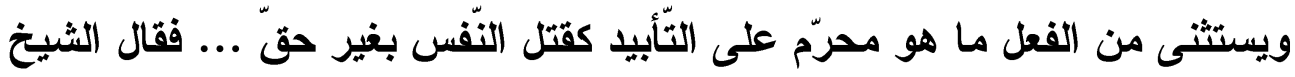
أبو إسحاق الثيرازي: انعقد الإجماع على أنّ المكره على القتل مأمور باجتناب

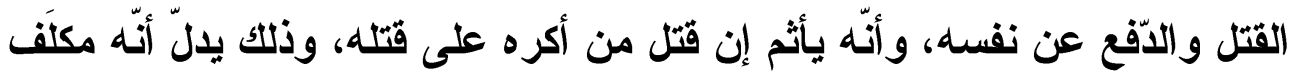
حالة الإكر اه " ("). ويرد الشوكاني على من منع تقية الفعل (๕) متعلقاً بسـبب ورود قوله

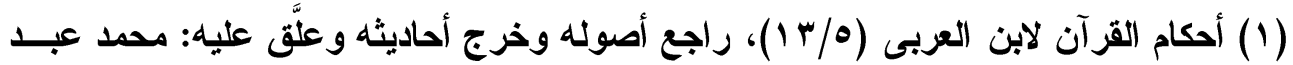

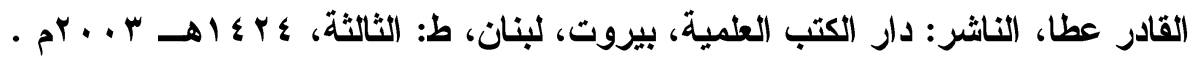

$$
\begin{aligned}
& \text { (r) فتح الباري لابن حجر (r/r/r/r) }
\end{aligned}
$$

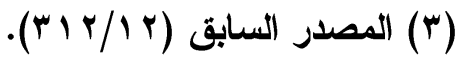

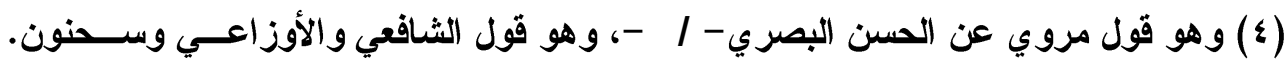

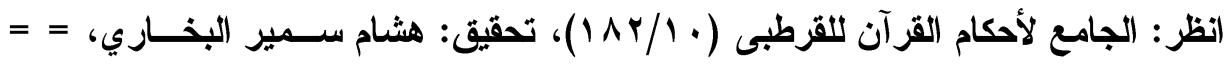

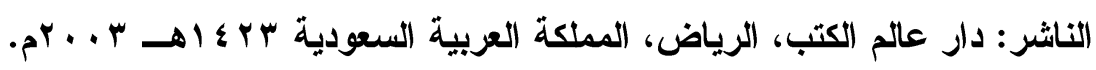


تعالى: \} إلا من أكره وقلبه مطمئن بالإيمان \{(')، فإنها نزلت في عمار، وقد أباح

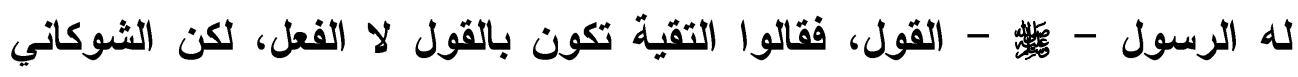
يرده، ويرى أنه قول مردود: " يدفعه ظاهر الآية، فإنهّا عامّة فيمن أكره من غير بهول فرق بين القول والفعل، ولا دليل لهوُلاء القاصرين للآية على القول، وخصوص السبب لا اعتبار به مع عموم اللفظ، كما تقرّر في علم الأصول " (؟). وقد فسرها بنحو هذا الثيخ حسنين مخلوف فقال: " إلا أن تتقوا منهم تقاة أي: إلا أن تخافوا منهم مخافة أو تخافوا من جهتهم أمرا يجب اتقاؤه من الضرر في النفس أو المال أو العرض، وذلك إذا كان الكفار غالبين ظاهرين أو أو أون كنتم في قوم كفار فيرخص لكم في مداراتهم باللسان على أن لا تنطوي قلوبكم على شيء في مودتهم، بل تدارونهم وأنتم لهم كارهون وألا تعملوا ما هو محرم كشرب الخمر، واطلاعهم على عورات المسلمين والآحياز إليهم في مجافاة بعض هودئ المسلمين فلا رخصة إلا في المدار اة باللسان " (") .

(1) سورة النحل من الآية (ף • (1).

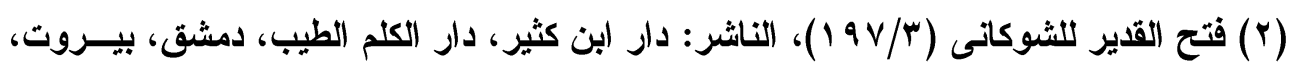

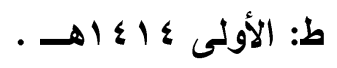

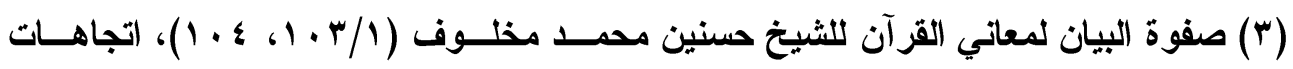

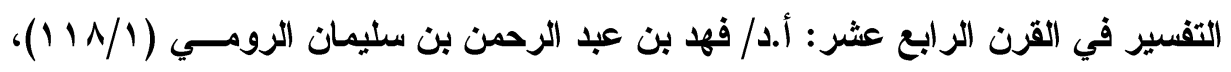

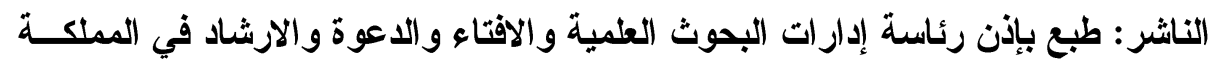

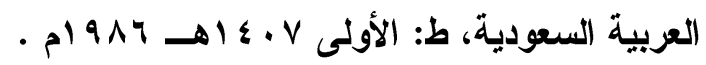




\section{ثانيا: التهريف بالخهارج:}

تعربف الفوارج فيى اللغة:

الخوارج في اللغة جمع خارج، وخارجي اسم مشتق من الخروج، وقد أطلق علماء اللغة كلمة الخوارج في آخر تعريفاتهم اللغوية في مادة (خرج) على هذه الطائفة من الناس؛ معللين ذلك بخروجهم عن الاين أو على الإمام علي، أو اجو

لخروجهم على الناس (')

في الاصطلم:

\section{اختلف العلماء في التعريف الاصطلاحي للخوارج، وحاصل ذلك:}

ا.منهم من عرفهم تعريفاً سياسياً عاماً، اعتبر الخروج على الإمام المتفق على إمامته الشرعية خروجاً في أي زمن كان.

قال الشهرستاني: "كل من خرج على الإمام الحق الاي اتفقت الجماعة

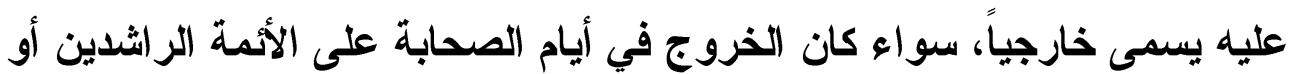

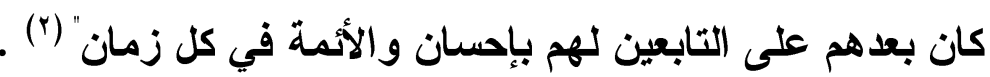
فالشهرستاني عرفهم تعريفا عاما فاعتبر الخروج على الإمام الأي اجتمعت الكلمة على إمامته الثرعية خروجا في أي زمان.

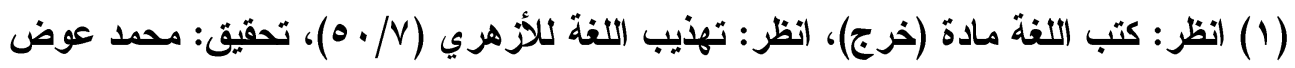

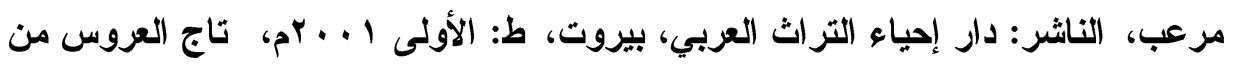

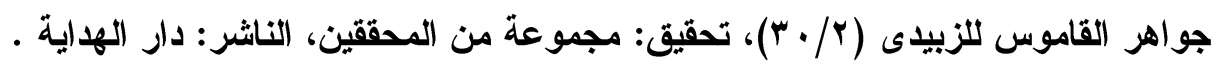

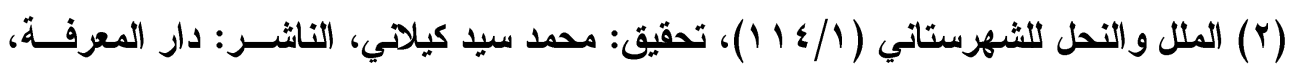




\section{د. قتحي محمود محمد عبد الرحمز}

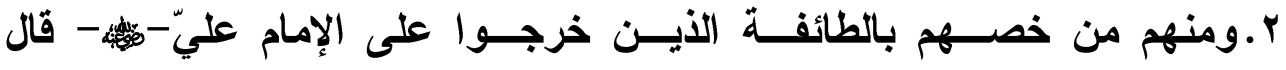

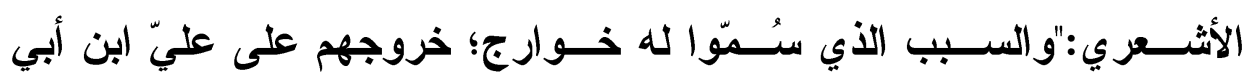

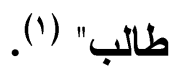

فعرفهم أبو الحسن الأثثري تعريفا خاصا حيث بين أن اسم الخارجي يقع على تلك الطائفة التي خرجت على رابع الخلفاء الراشدين وأن ذلك هو العلة في تسميتهم بهذا الاسم، زاد ابن حزم بأن اسم الخارجي يلحق كل من أثببه الخارجين على الإمام عليّ أو شاركهم في آرائهم في أي زمن. وهو يتفق مع

تعريف الثهرستاني (r).

فكل من خرج على الإمام الحق الذي اتفقت الجماعة عليه يسمى خارجيا

سواء كان الخروج في أيام الصحابة على الأثمة الراثدين أو كان بعدهم على الأهام التابعين بإحسان والأثمة في كل زمان.

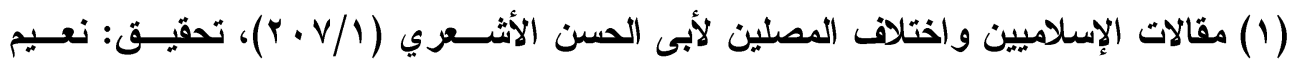

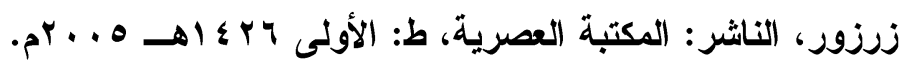

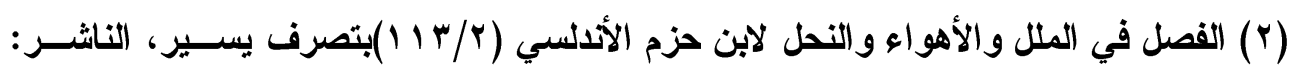

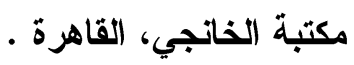




\section{ثالثا: تعريف أهل السنة:}

السنّنة في النغة:

السنَة في اللغة مشتقة من: سنَ يَسِن، ويَسُن سنَّا، فهو مَنْنُون. وسنَن

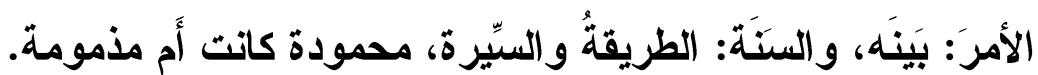

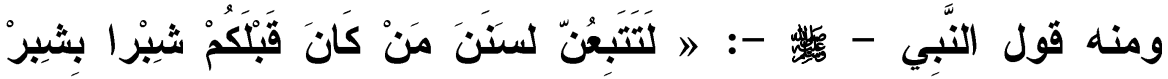

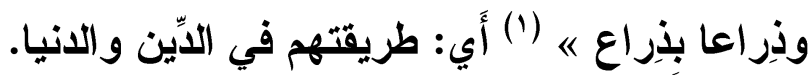

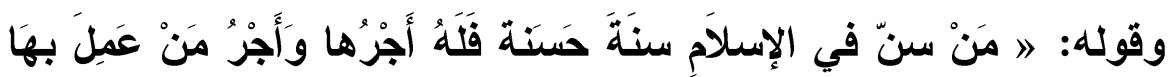

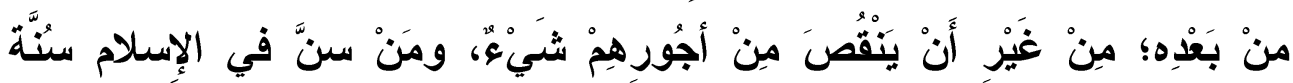

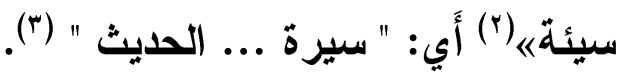

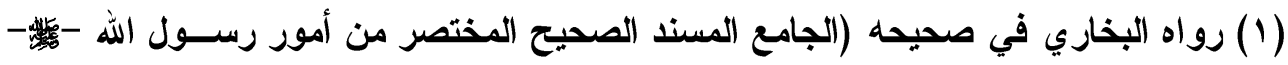

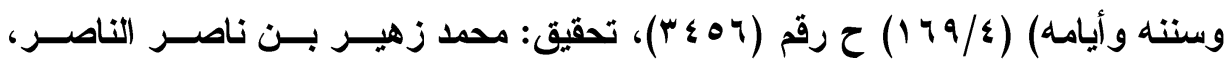

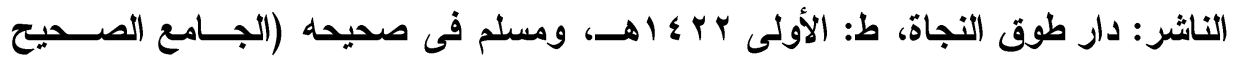

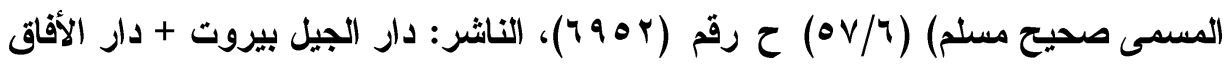
الجديدة، بيروت.

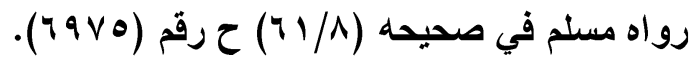

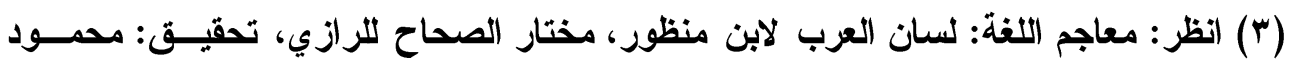

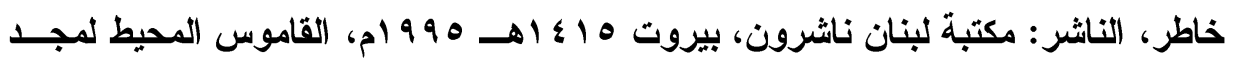

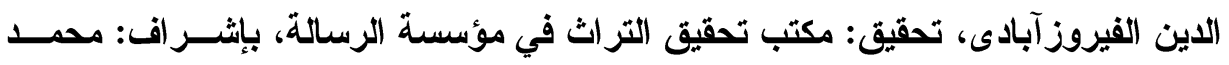

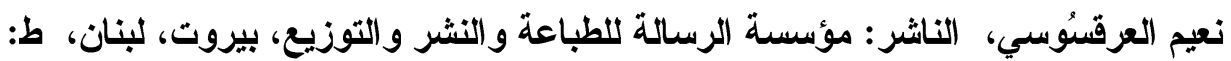

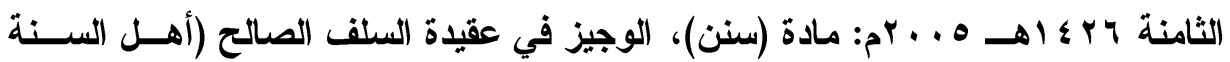

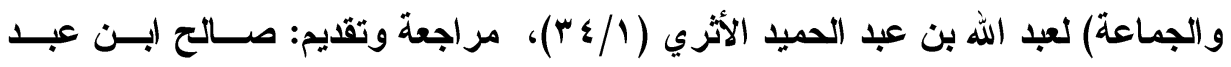

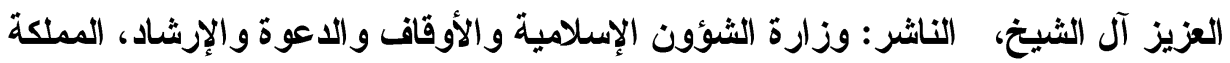

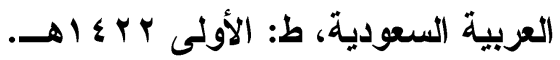

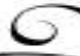


السنة فيى الاصطلام:

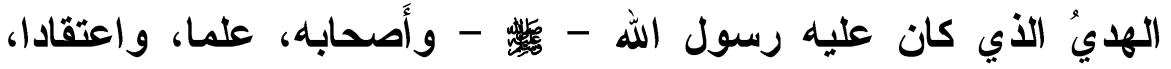
وقولا، وعملا، وتقريرا. وتُطلق السينّة أَيضا على سنْنَ العبادات والاعتقادات،

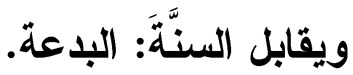

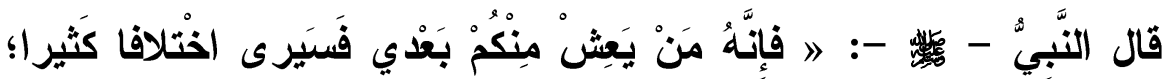

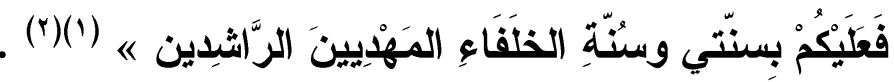

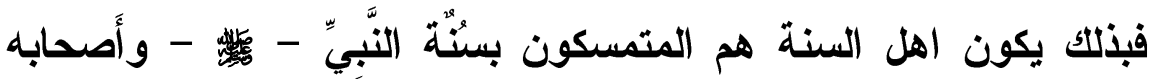
ومَن تبعهم وسلتكَ سبيلهم في الاعتقاد والقول والعمل، والأين استقاموا على الاتباع وجانبوا الابتاع، وهم باقون ظاهرون منصورون إلى يوم القيامة فاتباعُهم

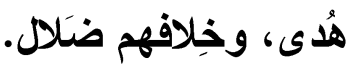
فصفوة القول في مفهوم أَهل السئنة والجماعة: أنهم الفرقــة التي وعدها التبَّي ومو(ققة ما جاء بها من الاعتقاد والعبادة والهدي والسلوك والأخلاق، وملازمة جماعة المسلمين. وبهذا لا يخرج تعريف أَهل السنّّة والجماعة عن تعريف السلف، فالسلف

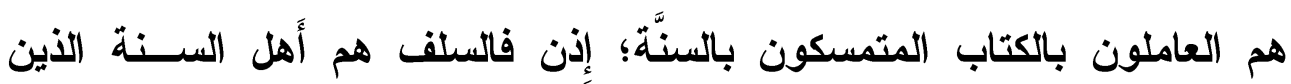
عناهم النبي - هم: - وأَهل السنة هم السلف الصالح ومن سار على نهجهم(").

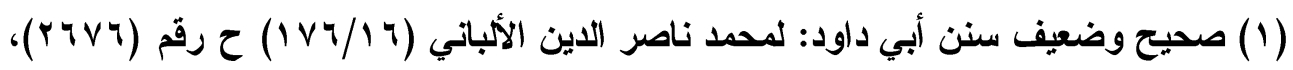

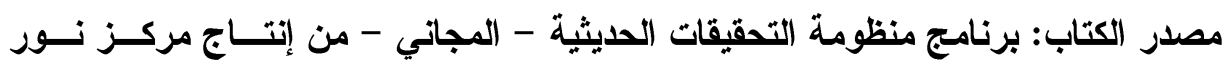
الإسلام لأبحاث القرآن و السنة بالإسكندرية. (r) انظر : معاجم اللغة: لسان العرب، مختار الصحاح، القاموس المحيط: مادة: (جمع)، الوجيز الإنيز

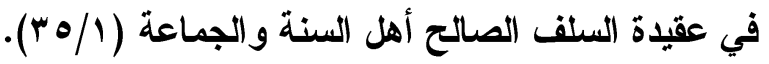

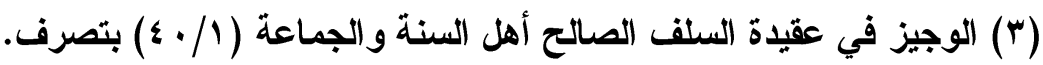


وهذا هو المعنى الأخص لأَهل السنة والجماعة؛ فيخرج من هذا المعنى كل طوائف المبتدعة وأَهل الأَهواع، كالخوارج، والجهمية، والقدرية، والمعتزلة،

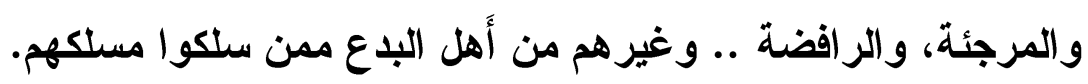
فهذا الأي قصده ترجمان القرآن، عبد الله بن عباس - ب - في تفسير مئر

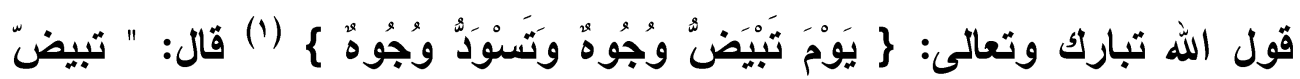

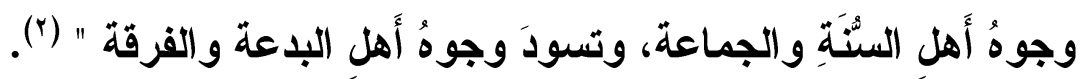

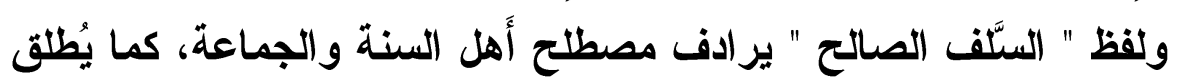
عليهم - أَيضا - أَهل الأثر، وأَهل الحديث، والطائفة المنصورة، والفرقة الناجية، وأَهل الاتباع، وهذه الأَسماء والإطلاقات مستفيضة عن علماء السلف.

(1) سورة آل عمران من الآية (7 (1) (1) (1).

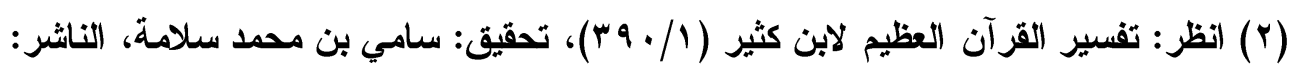

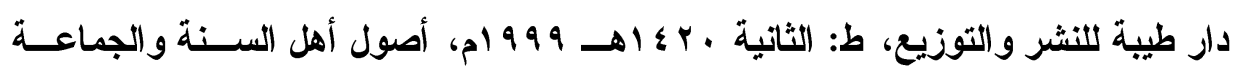

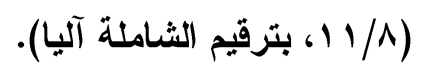




\section{المبمث الثاني \\ أراء وأقوال الفهارج في التقيـة}

:4000

إن الصراحة في القول والجهر بما تنطوي عليه النفس دون مراعاة أحد أو الخوف منه سواء كان حاكما أو محكوما يتمثل في أوضح صورة لاى الخوارج؛ فهم يرون أن عدم الجهر بالقول الذي يعتقده الشخص حقا ليس من صفات الرجل الواثق من عقيدته، بل هو من صفات المنافقين المرتابين، وقد كاتت سيرتهم في الخروج والكفاح مثنلا واضحا، كماهو واضح في التاريخ لحركات من هن الخوارج الثورية.

ولقد كان نافع بن الأزرق(') أقوى معبر عن ذلك بما ذهب إليه من تحريم

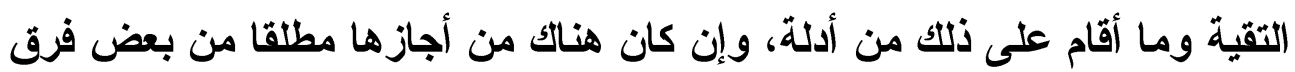
الخوارج الأخرى مخالفة له في ذلك، ومن توسط في أمرها كما سنبين ذلك فيما

ولقد كان الاختلاف في شأن التقــية من الأســباب التي فرقت بين نافـع

ابن الأزرق زعيم الأزارقة وبين نجدة بن عامر(؟) زعيم النجدات وهما من أوائل

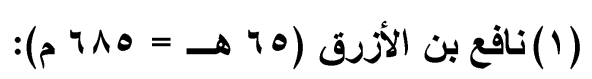

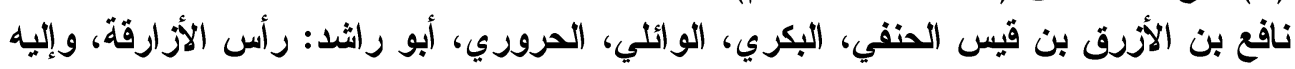

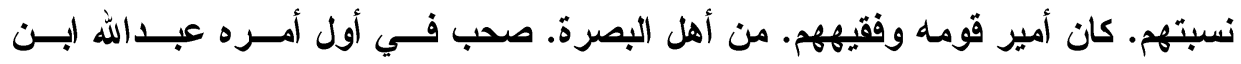

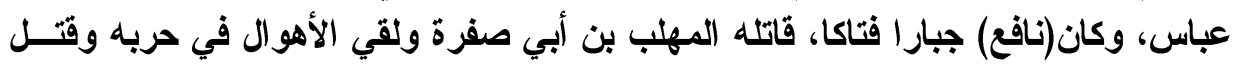

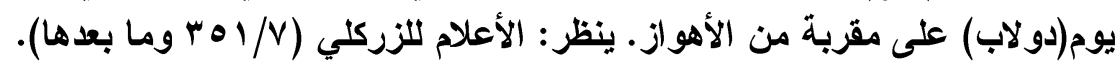

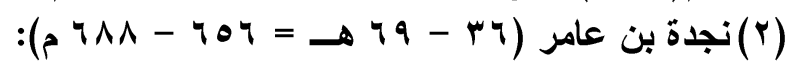

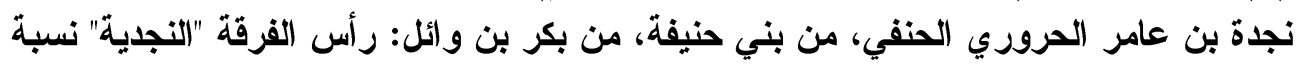

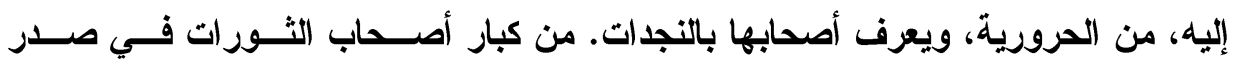

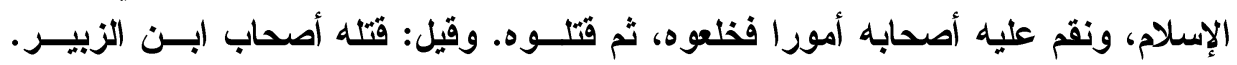

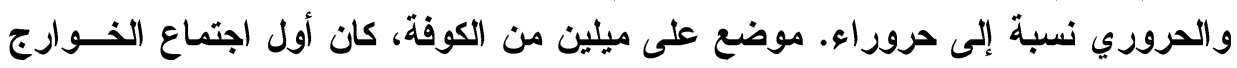

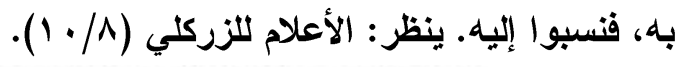

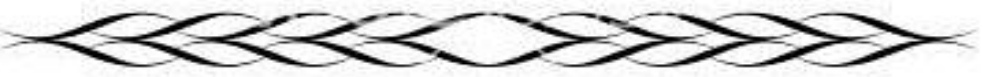


الخوارج وأثدهم بأسا، قال الشهرستاني مبينا سبب ذلك الاختلاف بينهما: "وكان سبب اختلافهما أن نافعا قال: التقية لا تحل والقعود عن القتال كفر" - إلى أن يقول: "وخالفه نجدة وقال: التقية جائزة" (1) وسنبين ذلك بالتفصيل فيما يأتي. ونبدأ ببيان رأي الخوارج في التقية، لقد تعددت اقوال الخوارج في التقية

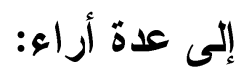

\section{أولا: القائلون بـعدم جواز النقبية وأدلتهم:}

إن القول بعدم جواز التقية هو رأي الأزارقة، أَتْبَاعُ نَافِعِ بْنِ عَبْدِ اللَّهِ

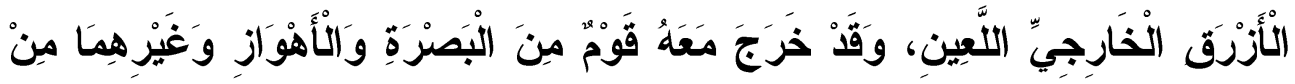

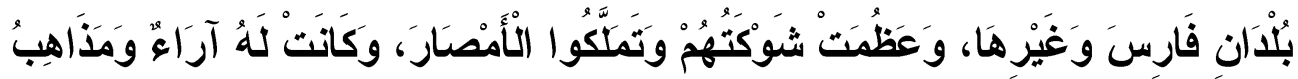

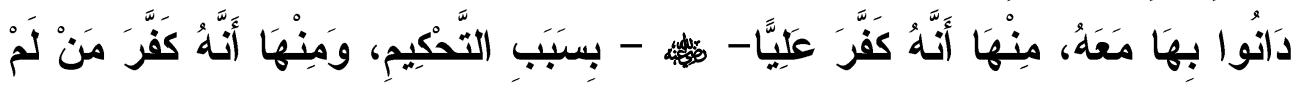

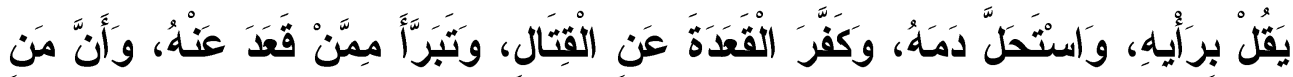

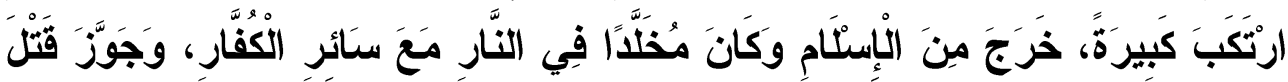

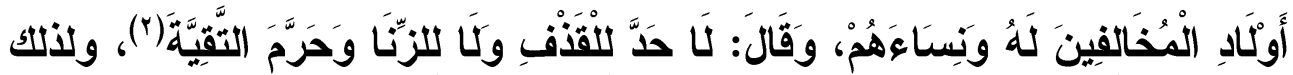
فقد كان نافع بن الأزرق من أثند المبغضين للتقية ويرى أنها تنافي وجوب الجهاد

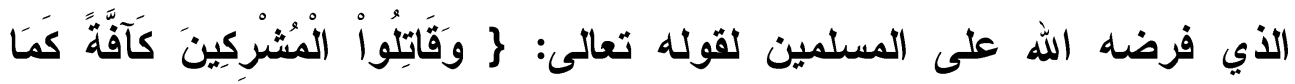

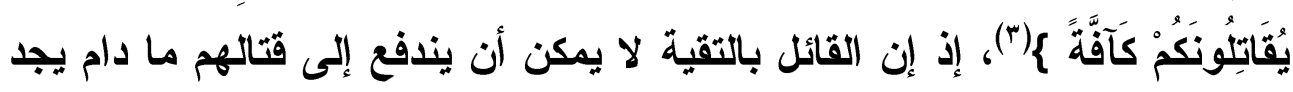

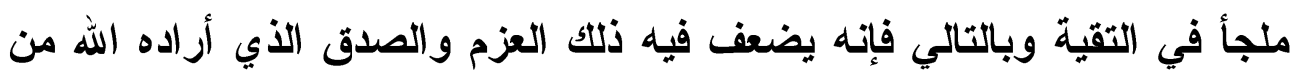
المجاهد، ولذلك فقد "برئوا من أهل التقية" (๕) كما قال الأشعري، وبالتالي فلا محل

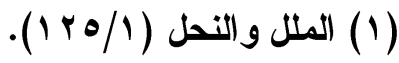

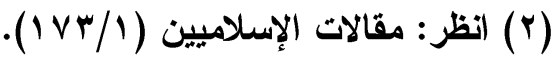

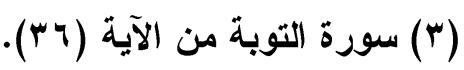

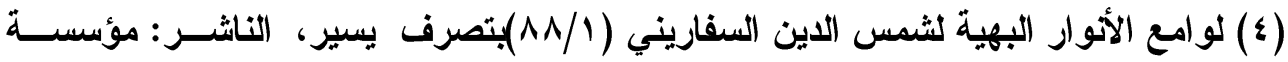

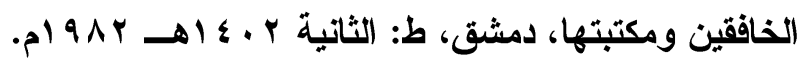




\section{د. قتحي محمود محمد عبد الرحمز}

لها عندهم ولا منزلة لها بينهم سواء كانت في الأقوال أو الأفعال. وقد عد الشهرستاني هذا القول من بدعهم وضلالتهم أي قولهم: "إن التقية غير جائزة في

قول ولا عمل" (1)

فنافع بن الأزرق قد كفر جميع المسلمين من عداهم، واستباح قتل النساء

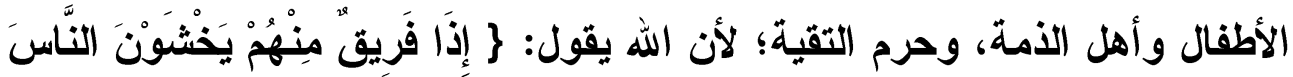

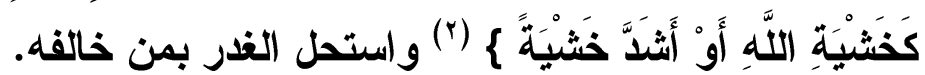
ويقول أحمد أمين مقارنا بين الخوارج والثيعة في الأخذ بالتقية: " وعلى الثل عكس الثيعة في القول بالتقية الخوارج فقالوا: لا تجوز بحال من الأحوال ولو عرضت النفس والمال والعرض للأخطار، وحياة الثيعة والخوارج السياسية مظهر من مظاهر قولهم في التقية، فالخارجي يعلن الخروج على الإمام في صراحة ولو كان وحده ويحاربه ولو كان في نفر قليل مهما بلغ عدوه من (العدد " (r) (

وكلام أحمد أمين يصدق على الأزارقة وأصحاب الحركات الثورية من الخوارج، وقد يصدق على غيرهم من الفرق الأخرى التي ترفض التقية وإن لم يروي المؤرخون في ذلك عنهم شيئا بخلاف من يجيزون التقية كالنجدات والصفرية والإباضية وغير هم ممن سنعرض رأيهم .

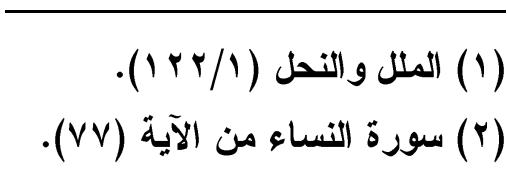

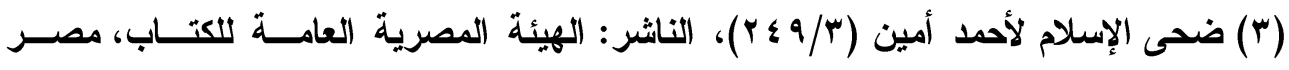

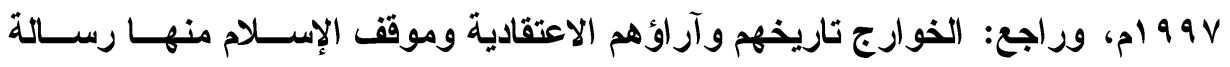

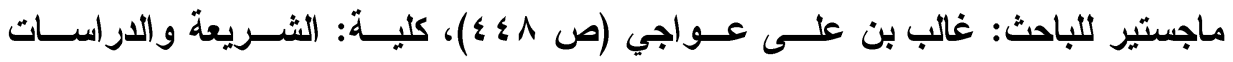
الإسلامية، جامعة: المثلك عبدالعزيز، مكة، السعودية.

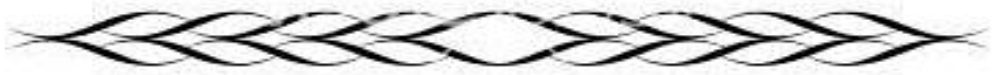




\section{أدلة الفوارج المانـهين للنثقية:}

استدل نافع على تحريم التقية بآيات من القرآن الكريم وردت في الأصل، إما في المشركين أي مشركي العرب وغيرهم، وإما في المنافقين، ولكن نافعا جعل حكمها شاملا لمخالفيه من أهل القبلة ومنطبقا عليهم، فاستدل على منع التقية

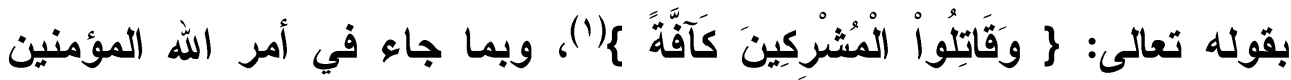
بالجهاد على ما تيسر من حال بعد أن قطع العذر في التخلف فقال: \} انْرِوُواْ خِفَافًا

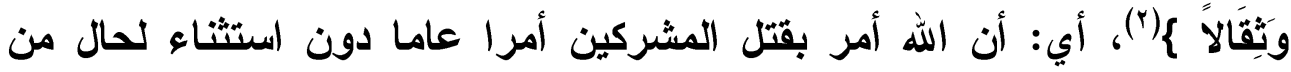
الأحوال يجوز فيه القعود عن قتالهم على سبيل التقية. واستدل أيضا بقوله تعالى:

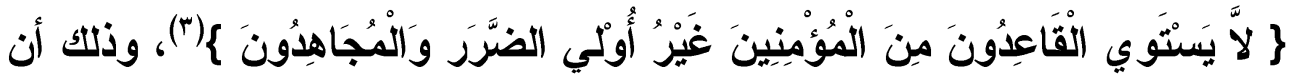
الله تعالى وإن كان قد عذر الضعفاء والمرضى والأين لا يجدون ما ينفقون ومن كانت إقامته لعلة، إلا أنه فضل مع ذلك المجاهدين، وأخبر أنهم لا يستوون عنده في الثواب مع غيرهم من أصحاب الأعذار ومنهم القاعدون عن القتال تقية، وقد استدل نافع كذلك على تحريم التقية بما وصف الله به القعدة في قوله تعالى:

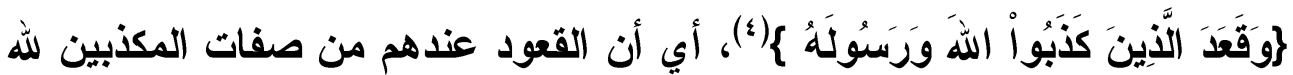
ورسوله وهم غير المؤمنين. واستدل أيضا بأن الله قد ذم الأين يخشون غيره من الناس أو تكون خثيتهم من الناس أثد من خثيتهم من الله وهو من لوازئه

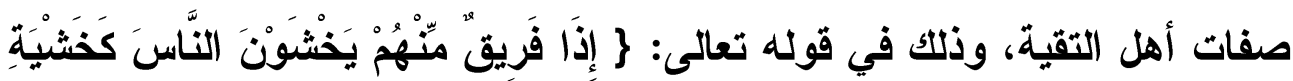

(1) سورة التوبة من الآية (؟r).

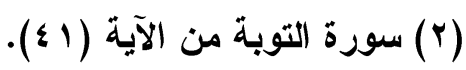

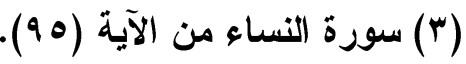

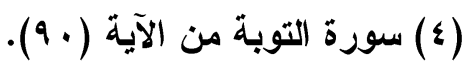




\section{د. فتحي محمود محمد عبد الرحمز}

اللهِ أَوْ أَثَدَّ خَثْيَةً ج|')، ثم مدح تعالى نقيض هؤلاء وهم المجاهدون الأين لا

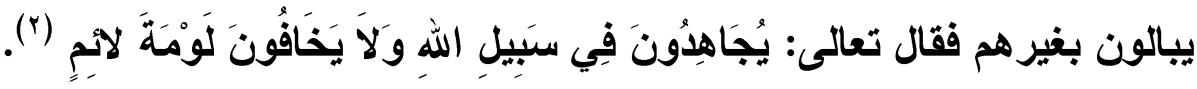
ثانيا: القائلوز بجواز النتقبة وأدلتهم:

القول بجواز التقية قولا وعملا وهو رأي النجدات، النجدات العاذرية: ينسبون إلى نجدة بن عامر الحنفي، وكان من شأنه أنه خرج من اليمامة

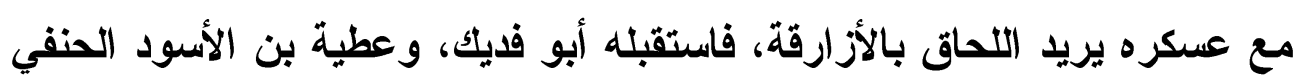
في الجماعة الذين أنكروا على نافع بن الأزرق بدعه، فأخبروه بما أحدثه من

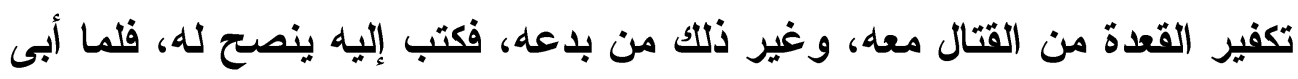
نافع أن يرجع، بايعه على الإمامة أبو فديك، وعطية ومن معهما، وسموه بأمير المؤمنين.

ومن بلاعهم: جواز التقية في القول والعمل، وتناصفهم فيما بينهم بلا إمام، فإن عجزوا عن ذلك إلا بالإمام جاز لهم أن يقيموه()، قال الثهرستاني فيما يحكيه عن الكعبي: " وحكى الكعبي عن النجدات أن التقية جائزة في القول والعمل

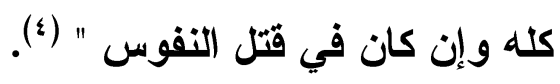
وتحليل النجدات للتقية، والرضى عن القعدة إنما هو لهم، أما أهل الأمة

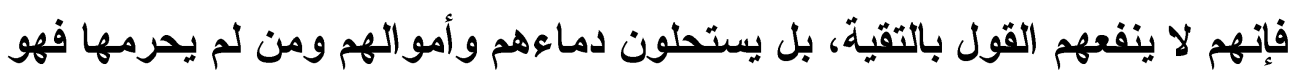

$$
\text { (Y) سورة النساء من الآية (YV) سورة المائدة من الآية (ع ه). }
$$

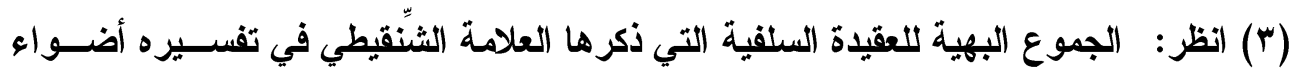

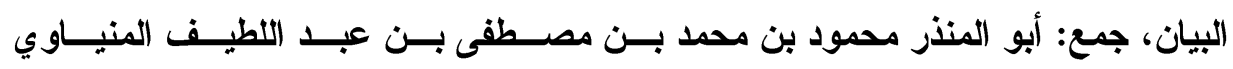

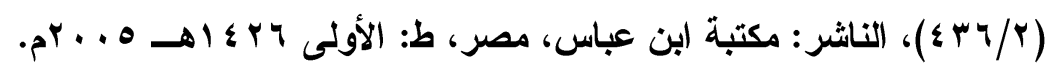

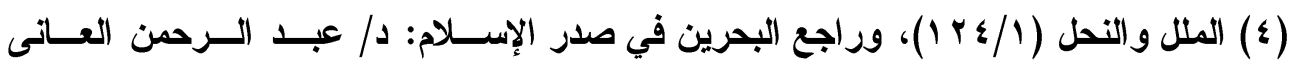

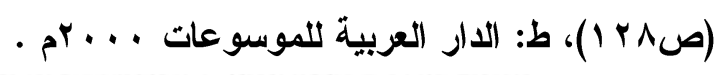

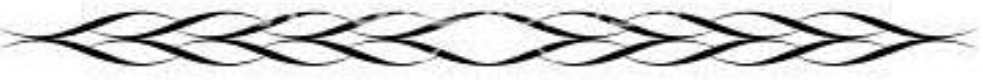


منهم في منزلة البراءة، وفي هذا يقول الأشعري: "وحكي عنهم أنهم استحلوا دماء أهل المقام وأموالهم في دار التقية وبرئوا ممن حرمها" ('). وهذا بخلاف ما ما فيول عرف عن الخوارج من تسامع مع أهل الأمة وتواصيهم بهم خيرا في أنفهرم وأموالهم كما اشتهرت بذلتك أكثر فرقهم.

ومن القائلين بجوازها من الخوارج أيضا: أبو بلال مرداس()، الثخصية

المثالية المحبوب لاى كل فرقهم، ويتبين تجويزه لها من موقفه مع البلجاء المرأة الخارجية المشهورة بمواقفها العنيدة من ابن زياد، فقد قال لها أبو بلال مشفقا عليها من بطش ابن زياد: "إن الله قد وسع على المؤمنين التقية فاستتري؛ فإن هذا المسرف على نفسه الجبار العنيد قد ذكرك "("). وبهذا قد ابتدع التجدات مبداً جديدًا لم يكن معروفًا عند الخوارج آنذاك، وهو مبدأ التقية ومعناه: " أن يظهر الخارجي أنه جماعي؛ حقنًا لامهه، ومنعًا للاعتداء عليه، ويخفي عقيدته حتى يحين الوقت المناسب لإظهارها واستحل نجدة بن عامر دماء أهل العها والأمة وأموالهم في حال التقية، وحكم بالبراعة ممن حرمها. قال: وأصحاب الحدود من مواققيه، لعل الله تعالى يعفو عنهم. وإن عذبهم فقي غير النار، ثم ياخلهم الجنة؛ فلا تجوز

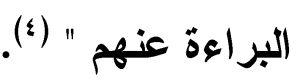

وممن أجازها أيضا من فرق الخوارج فرقة الإباضية، وسميّيت بذلك نسبة إلى عبد اللّه بن إباض المقاعسي المري التميمي (ت خ ^ه)، ويكثر تواجدهم اليوم في سلطنة عمان، والجزائر في المغرب العربي، وهم من القائلين بالتقية كما

$$
\text { (1) الملل والنحل (1/ إع ب). }
$$

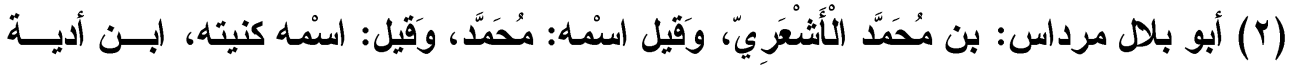

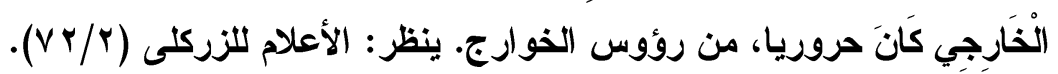

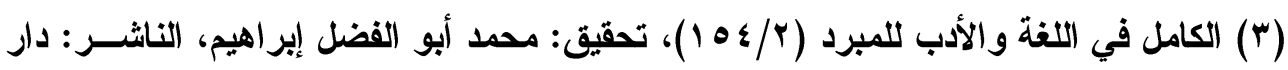

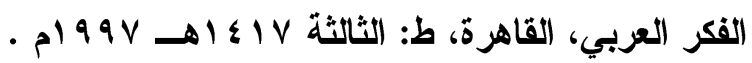




\section{د. فتحي محمود محمد عبد الرحمز}

की

التقية

عند الخوارج وموقف أهل السنة منها

صرّحت بذلك كتبهم الفقهيّة، فقد ورد في كتاب المعتبر لأبي سعيد محمّ بن سعيد الكدمي الإباضي، وهو من فقهاء الإباضية في القرن الرابع الهجري في باب (ما يجوز به معنى التقية في الأرحام ونحوهم من القول) ما نصيّه: 》 التقية في ذوي الأرحام، والجار، والصاحب جائزة، يظهر إليه الجميل والاعاء، حتّى أنتّك تحمد

أمره ولو كنت لا تتولاه « (')

وهذا هو قول أبي جابر محمّ بن جعفر الأزكوي الإباضي المتوفّى في النصف الثاني من القرن الثالث الهجري، وهو من أكبر أئمّة الخوارج الإباضية كما جاء في تقديم كتاب المعتبر. وفيه أيضاً: 》 والعذر في التقيّة في الدين فيما يجوز، كالعذر في التقية في النفس فيما يجوز... ومن كان في حال التقية جاز له أن يدعو لمن لا يتولاه بما يدعو به لأهل الولاية، ويعقد المعنى لغيره «(؟). ثمّ نقل عن الأزكوي المتقدّم قوله: 》 إن الجُبن في مواطن الحقّ نفاق «هُ وعقبه بقوله: 》 من غير تقية تسعُهُ وتجوزّ لله، وهو قادر على ذلك ... وأمّا إن كان الجُبن غريزة فيه لا يقدر على القيام بذلك العارض من الحقّ، أو كان الحقّ هيّ غير واجب عليه، أو كان في حال تقية توستع بها ممّا يسعه في دين أو نفس أو مال ... انّ هذا لا يكون من النفاق، وإنما النفاق ما أوجب الكفر من ركوب المعصية، وترك شيء من اللازم، أو ركوب شيء من المحارم بغير عذر لله في الاين «)

ثمّ قال: " وروي عن بعض أهل العلم اتّه كان يكتب إلى بعض من كان فسقه ظاهراً مع الناس - وأحسب انته كان من أعوان السلطان -، وكان في كتابه: حباك اللّه وحفظك...، ثمّ بيّن أنّ هذا القول لا يجوز أن يقال إلا على نحو

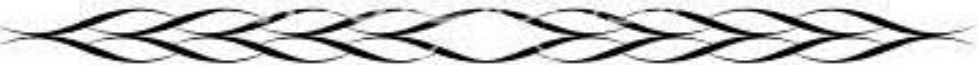


التقية، ثمّ قال: 》 إنّه جائز أن يتكلّم الإنسان بكلام على غير ما يكون، يريد به الإصلاح بين الناس، وصرف الباطل، و إدخال الحقّ... ولا يكون على هذه المعاني

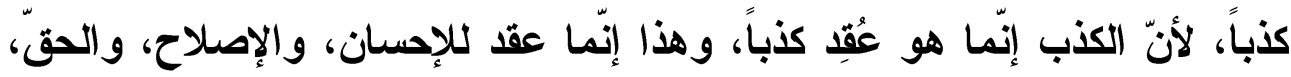

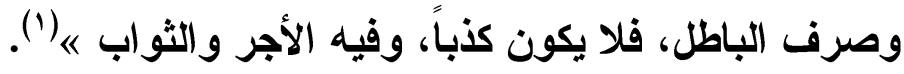
وقال السمدي الإباضي (ت ه هـ) في الفصل الثالث والأربعين في الصدق والكذب، من كتابه (المصنّف): 》 إنّه من كذب كذبة فهو منافق، إلا أن يتوب، فان

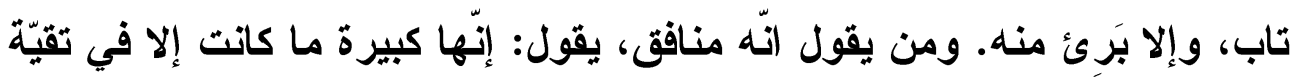
أو إصلاح «) (r)

وفي كتاب النيل وشفاء العليل للثيني الإباضي (ت ب r T اهـ) ما نصيّه :

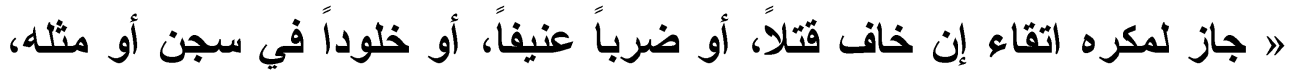
وقيل: حتّى يشار عليه بسيف أو سوط، والأوّل أليق «"(ّ).

وقال محمّّ بن يوسف اطفيش الإباضي (ت سrس اهـ) في شرح هذه العبارة: 》 (جاز لمكره اتقاء ... أو خلوداً) مكثاً طويلاً (في سجن أو مثثل) كقطع أنملة، أو حلق لحية، وفقء عين (وقيل حتّى يشار عليه بسيف أو سوط) أو

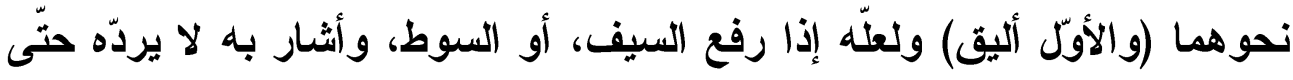

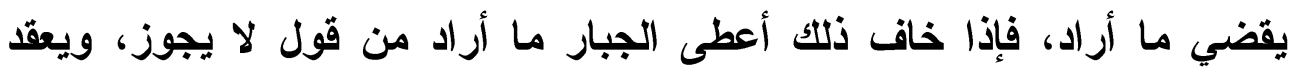
خلافه في قلبه، أو من فِعل إن أجاز العلماء التقية بـه. وعن بعض: ما من كلمة ترفع ضربة أو ضربتين إلا أقولها، وأجاز بعضهم

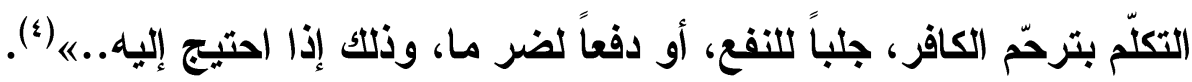

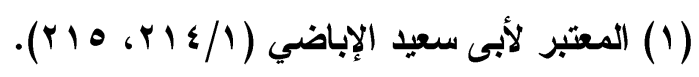

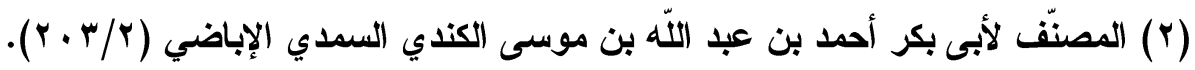

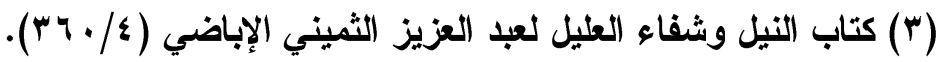

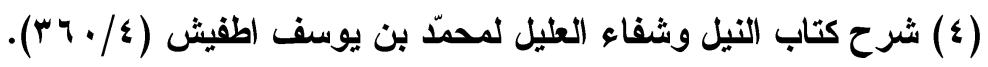




\section{د. قتحي محمود محمد عبد الرحمن}

وقد قصر في النيل الإكراه على الشــروع بالضـرب، فردّه الشــارح بقوله: 》 والصحيح ما مرّ إنّه تسعُهُ التقية إذا خاف ولو قبل الثروع. ومن استحلفه السلطان بالطلاق، أو الإعتاق وخاف إن لم يحلف أن يفعل به ما مرّ، أو ضربة، أو ضربتين - على قول - جاز الحلف بهما، وكذا إن اكرهه عليهما بلا تحليف جاز له (النطق بهما «) (1).

كما ورد في كتاب النيل: انّ السلطان إذا نادى إلى بيعته، فذهب شخص إليه، وحلف على البيعة لزمه ما حلف عليه إن حنث(؟). قال الشارح: " من لم يجئ عاقبته بقتل أو ضرب أو نحو ذلتك، جاز

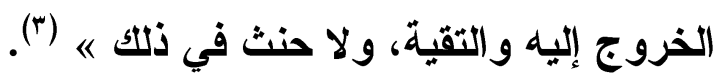

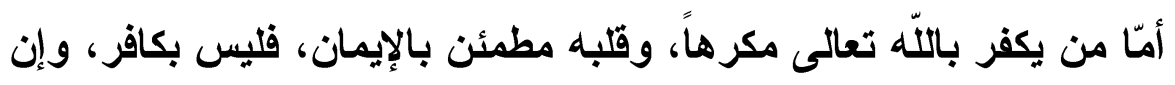

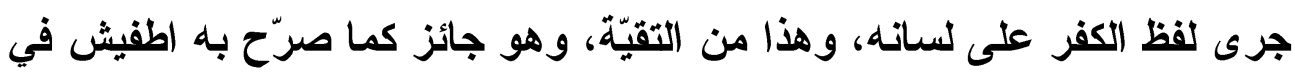
تفسيره(؛)، مع حرمة التقية عنده على القتل أو الزنا، واتّه لا يعذر من يقتل أو هن يزني وإن كان مكرهاً.

\section{هـ - أدلة القائلين بجواز النتقية:}

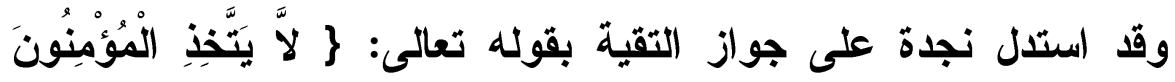

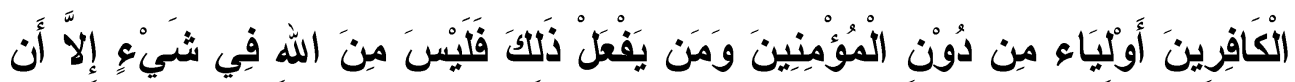

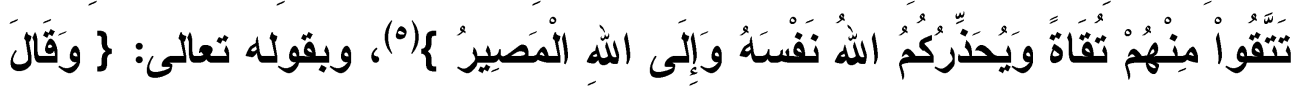

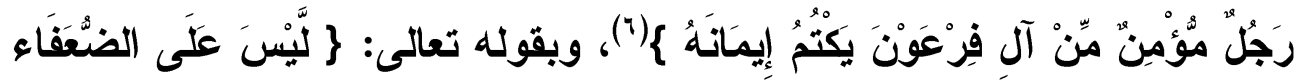

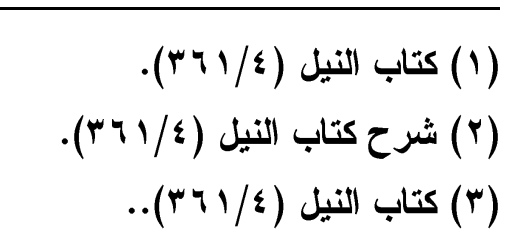

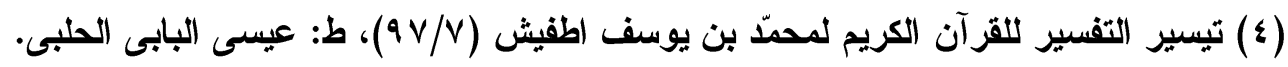

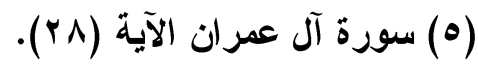

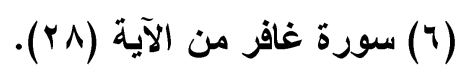




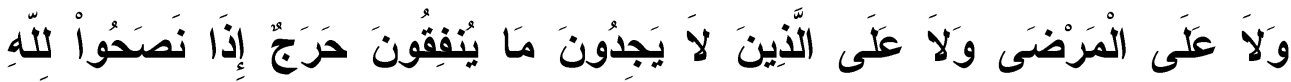

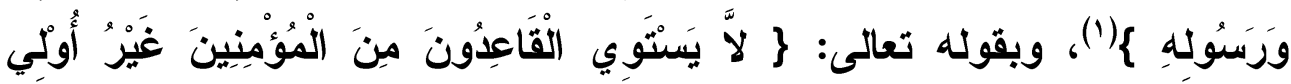

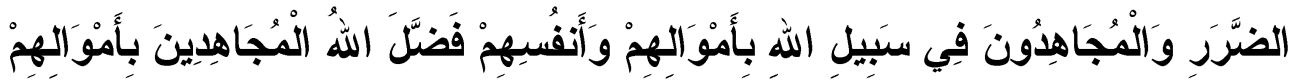

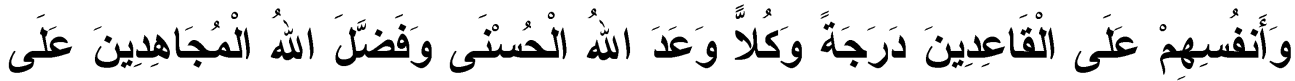

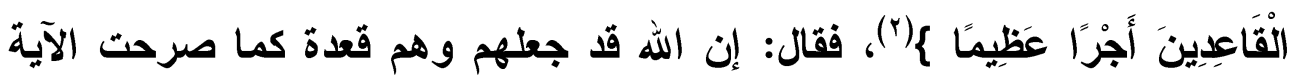

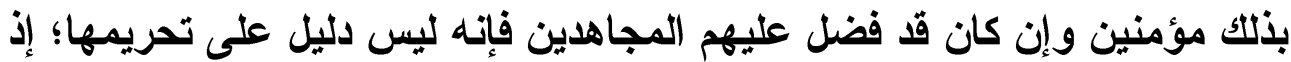
لو كانت محرمة لما سماهم مؤمنين، ولما كاتت مفاضلة بينهم، ولعل هذا التوجيه

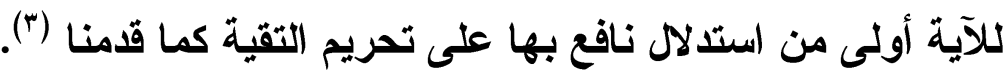
وكذلك استدل الإباضية على جوائزها، بل قد تكون واجبة كما يظهر من الأحاديث التي ذكرها الربيع بن حبيب في مسنده، قال الربيع بن حبي: (باب: ما

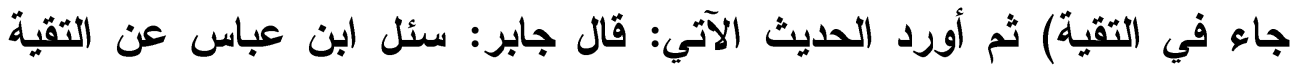

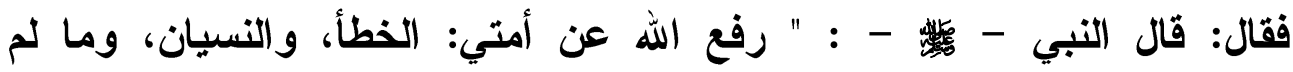

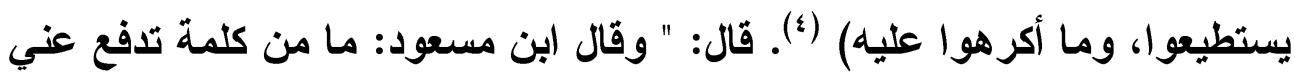

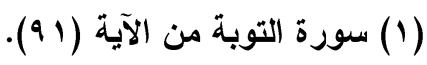

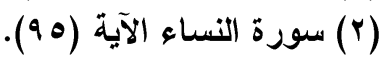

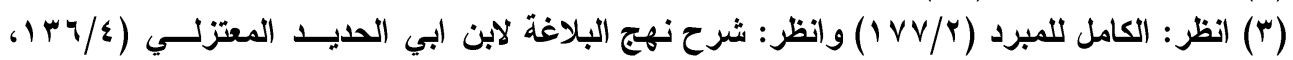

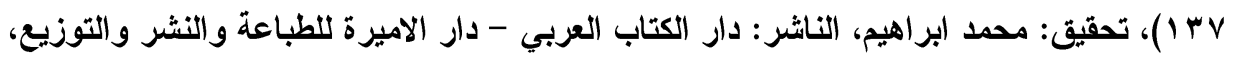

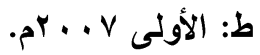

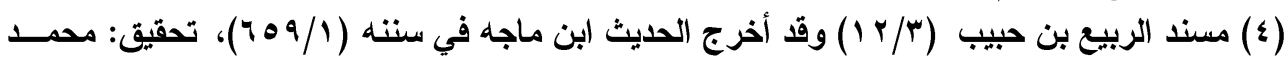

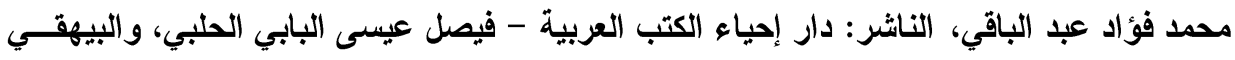

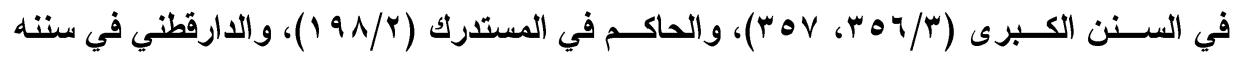

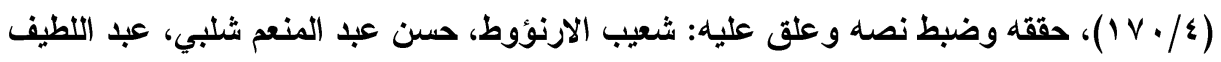

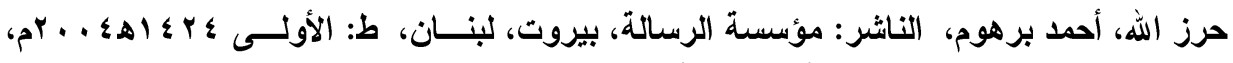

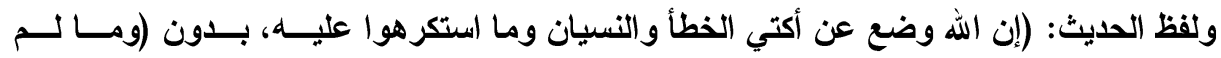

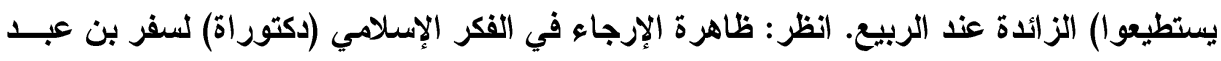

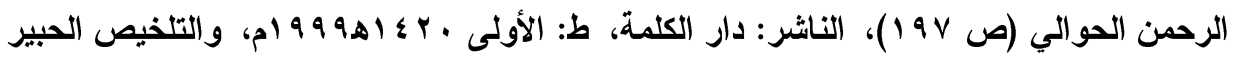

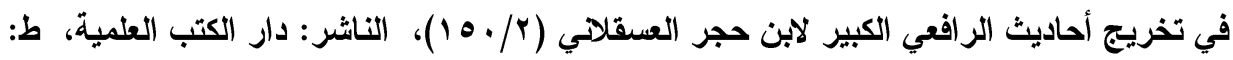

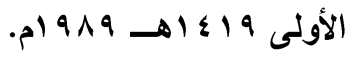




\section{د. قتحي محمود محمد عبد الرحمن}

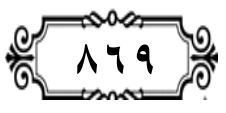

التقية

عند الخوارج وموقف أهل السنة منها

عني ضرب سوطين إلا تكلمت بها، وليس الرجل على نفسه بأمين إذا ضرب أو عذب أو حبس أو قيد) أي وهو يجد خلاصاً في الأخذ بالتقية " (') .

\section{السبب في افنتراق نـافز بـن الأزروق عن عامر بـن نـافر}

كان نجدة بن عامر، ونافع بن الأزرق قد اجتمعا بمكة مع الخوارج على ابن الزبير - رضي الله عنه - ثم تفرقا عنه. واختلف نافع ونجدة، فصار نافع إلى البصرة، ونجدة إلى اليمامة. وكان سبب اختلافهما أن نافعا قال: التقية لا تحل، والقعود عن القتال

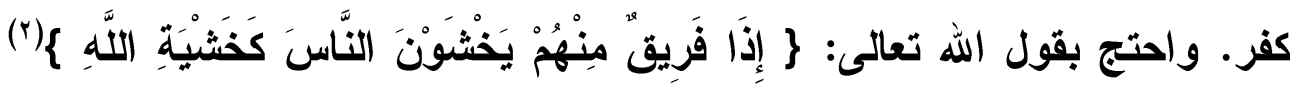

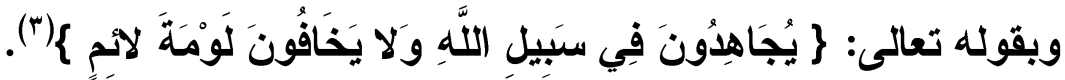

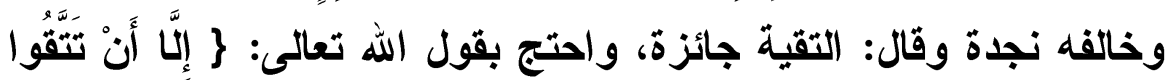

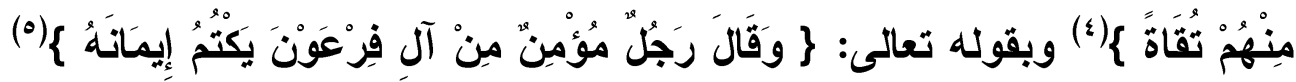

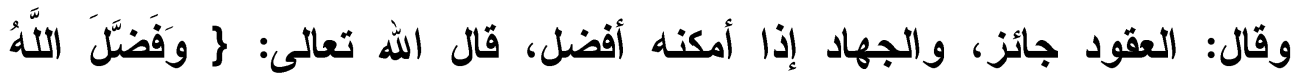

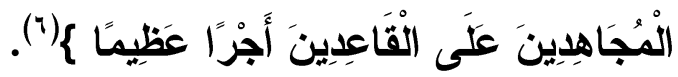

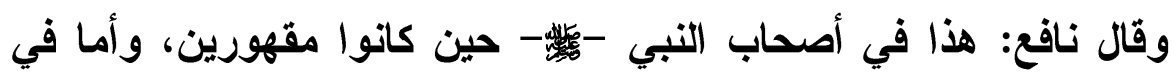

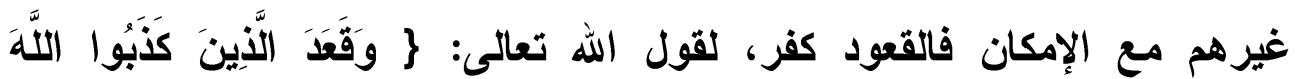

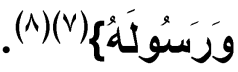

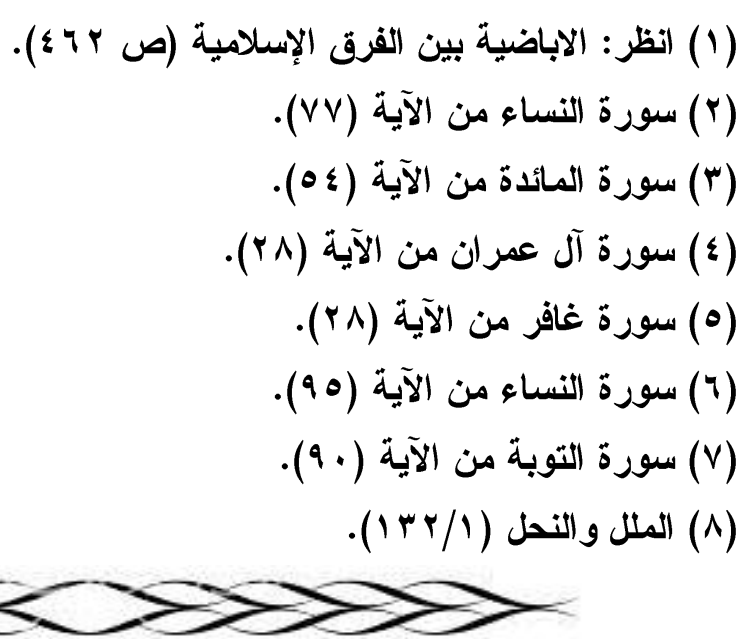




\section{ثالثا: القائلوز بجواز التقية في القول دوز العمل .}

القول بجواز التقية القولية دون العملية وهــو قــول الصــفرية(1) الـــين

توسطوا بين الأزارقة و النجدات، حيث أجازوا التقية في الأقهــوال لا فــي الأعمــال

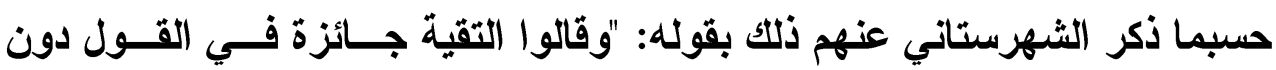
العمل"(). بل تختلف الأحكام عندهم في حال التقية عنها في حال العلانية، فقد جوز

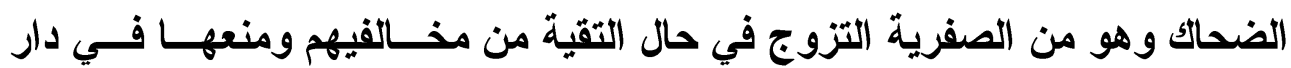
العلانية والغلبة لهم، ويختلف أيضا تنظيم الزكاة وسهامها في دار التقية، فقد جعلها زياد بن الأصفر سهما واحدا في حال التقية، كما يذكر ذلك الثهرستاني أيضا فـي قوله: " ونقل عن الضحاك منهم أنه جوز تزويج المسلمات من كفار قومهم في دار التقية دون دار العلانية، ورأى زياد بن الأصفر جميع الصدقات سهما واحدا في حال

التقية " (r)

فهم لم يسقطوا عقوبة الرجم كما فعل الأزارقة، وأجازوا التقية كالنجدات ولكن في القول دون العمل . ويذكر عن بعضهم تزويج المسلمات(؛) من كفار قومهم(•) في دار التقية دون دار العلانية(؟).

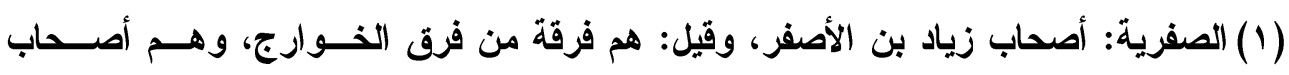

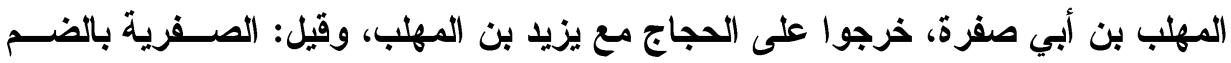

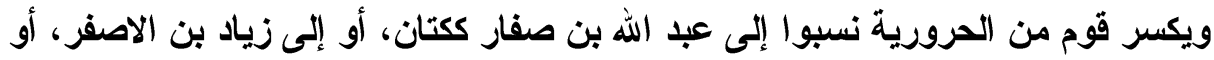

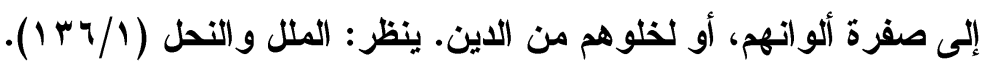

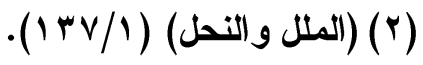

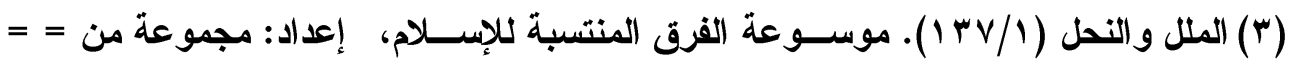

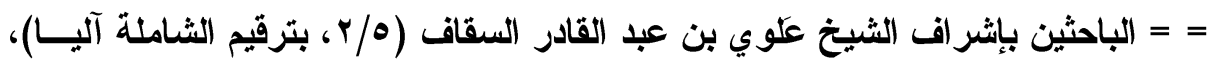

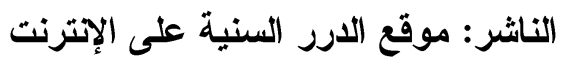

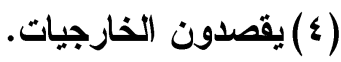
(ه) يقصدون بكفار قومهم بقية المسلمين.

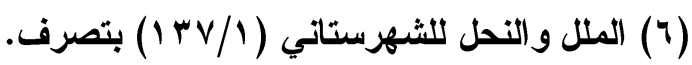


رابعا : الفوارج الذين توقفوا في النقبة:

الأخنسية: من فرق الثعالبة، أتباع أخنس بن قيس، انفرد عنهم بقوله: أتوقف في جميع من كان في دار التقية من أهل القبلة، إلا من عرف منه إيمان

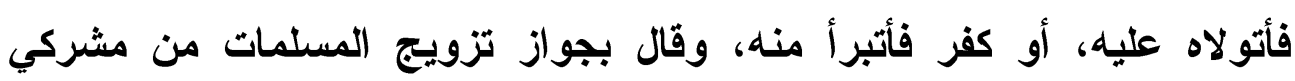
قومهم (1).

ومن ذلك يتضح ان الأخنس بن قيس قد خرج عن قول الثعالبة حين توقف عن جميع من في دار التقية من منتحلي الإسلام وأهل القبلة. وممن توقف في التقية قوم يُقَال لَهُم الضحاكية(؟) وأجازوا نَكَاح الْمسلمَة

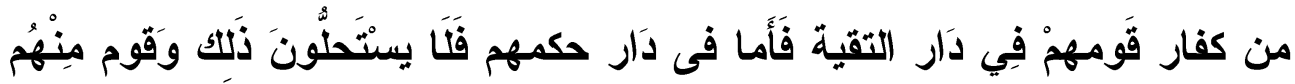

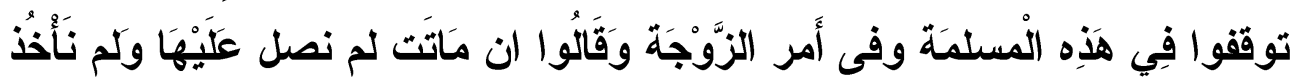

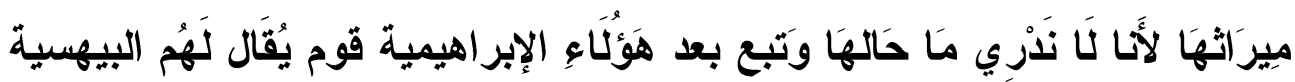

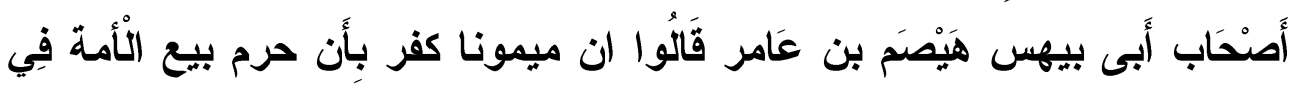

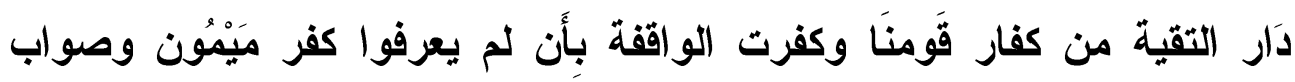

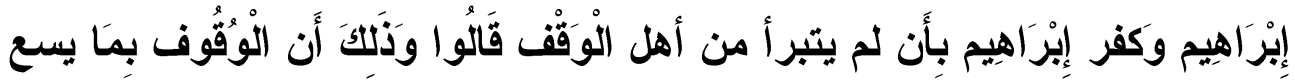

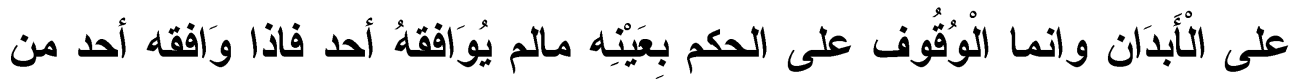

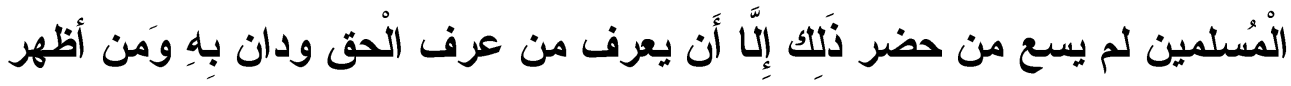

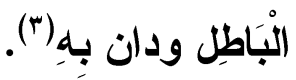

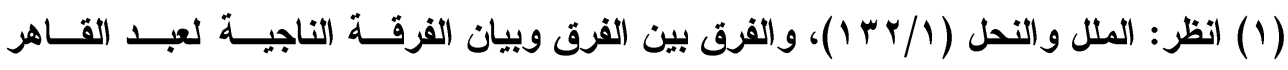

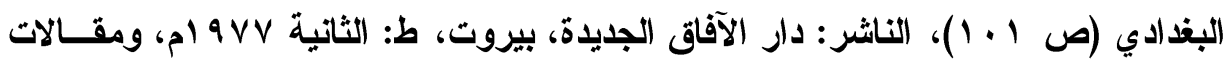

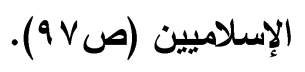

(Y) الضحاكية الو اققة: وردت تحت اسم الواقفة الفرق بين الفرق (ص ع ه)، وقد ذكر اسمها:

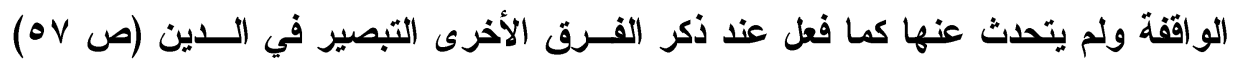

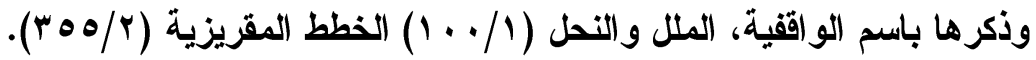

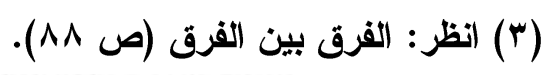


فالضحاكية أجازوا أن يزوجوا المرأة المسلمة عندهم من كفار قومهم في دار التقية كما يسع الرجل منهم أن يتزوج المرأة الكافرة من قومه في دار التقية فأما في دار العلاية وقد جاز حكمهم فيها فإنهم لا يستحلون ذلك فيها. ومن الضحاكية فرقة وقفت فلم تبرأ ممن فعله وقالوا: لا نعطي هذه المرأة المتزوجة من كفار قومنا شيئاً من حقوق المسلمين ولا نصلي عليها إن ماتت ونقف فيها، ومنهم من برئ منها('). وذكر اليمان أيضاً " أن صاحب الثمراخية وهو عبدالله بن شمراخ كان يقول أن دماء قومه حرام في السر حلال في العلاتية وأن قتل الأبوين حرام في دار التقية ودار الهجرة وإن كانا مخالفين، والخوارج تبرأ منه " (؟). والعطوية: منســوبة إلى "عطية بن الأســود الحنفي"، الأي فارق نافعاً ونجدة، منتقلاً إلى ســـستان بأرض فارس، وهــناك انتشر الخوارج وحكموا

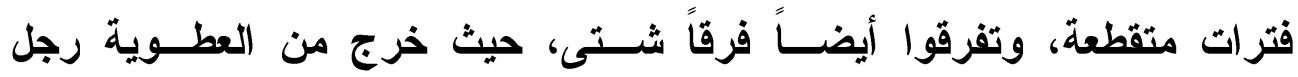

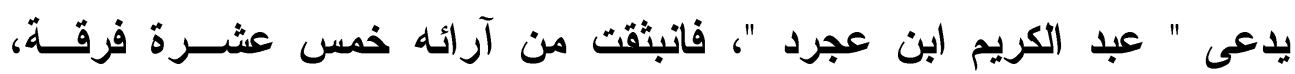

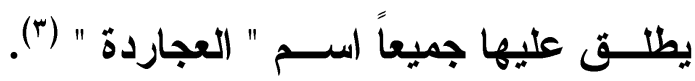
- وفرقة أخرى عممت التوقف فهم "يتوقفون عن جميع من في دار التقية، من منتحلي الإسلام وأهل القبلة، إلا من قد عرفوا منه إيماناً فيتولونه فئه

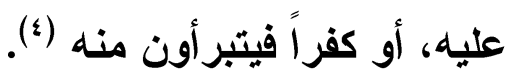

$$
\text { (1) مقالات الإسلاميين (ص • ب 1) بتصرف. }
$$

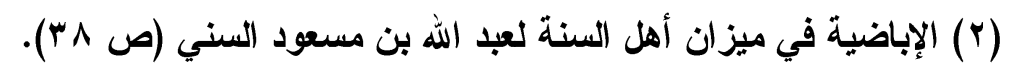

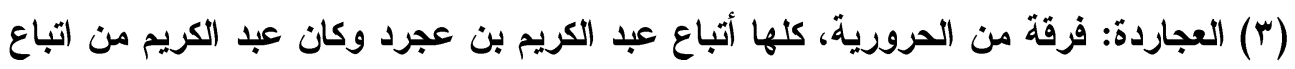

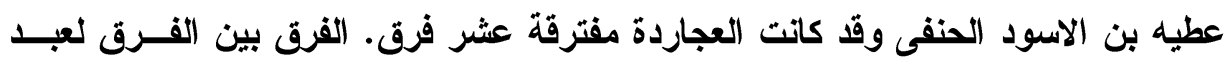

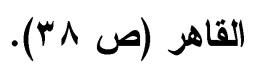

(£) انظر : ظاهرة الإرجاء في الفكر الإسلاهي (ص ^ • ץ). 


\section{الفرق بين الشيعة والفوارج في مبدأ النتقية}

إن الخوارج يعتمدون على الصدق والمكاشفة، ولا يضمرون شيئاً، والثيعة يعتمدون على التقية والمواراة والآتفات، والخوارج قوم يظهرون ما

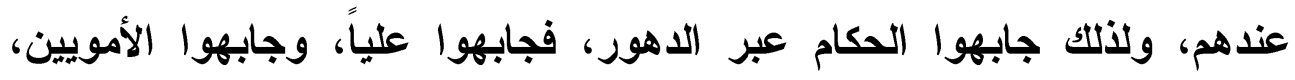
وجابهوا عبد الملك بن مروان، ولا يستثرون بشيء، ولكن الثيعة قوم يتحايلون؛ لأنهم قوم يؤمنون بالتقية إلى وقت خروج المهاي الأي يزعمون ويرتئنبون

فالخوارج يعتمدون على الصدق؛ لأنهم يرون أن مرتكب الكبيرة كافر، فلا يكذبون، في حين أن الثيعة يعتمدون على الكذب؛ لأنهم يعتقدون جواز التقية، فيعتمدون على الكذب، والخوارج لا يرون الكذب أصلاً؛ لأنهم يزون أن مرتكب لئب

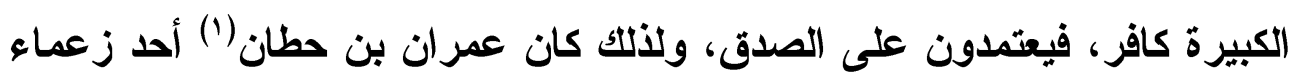
الخوارج وشعرائهم وأخرج له البخاري في الصحيع، اعتماداً على أنه لا يكذب أبداً في كلامه؛ لأثهم يرون أن مرتكب الكبيرة كافر، والخوارج أشد شجاعة، فهم لا يخافون الموت لا يهابونه عبر التاريخ كله، يقول قطري بن الفجاءة:

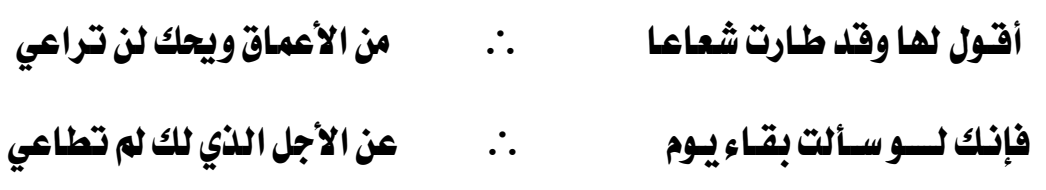

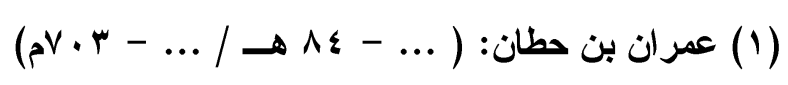

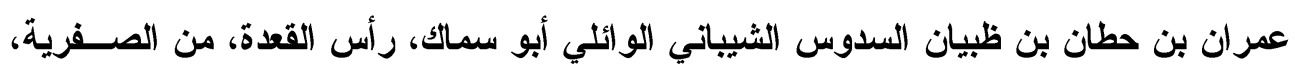

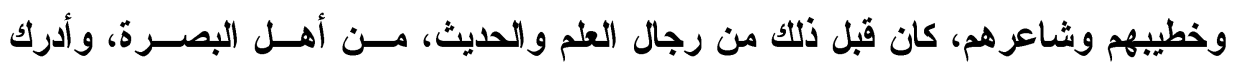

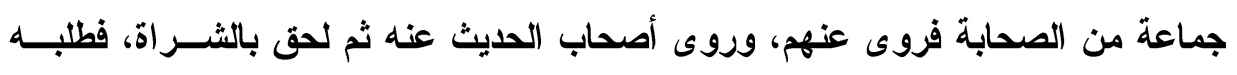

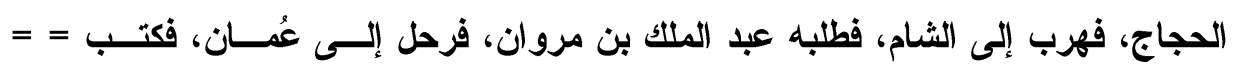

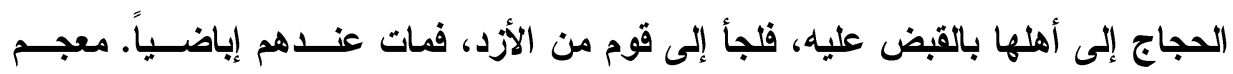

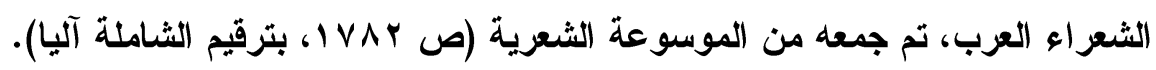

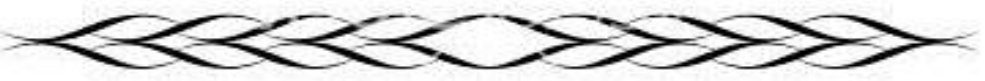




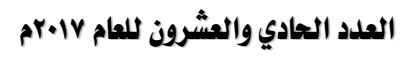

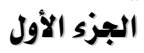

فما نيل الخلود بمستطاع

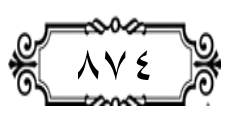

$\therefore$
حولية كلية اللفة العربية بجرجا

مجلة علمية محكمة

فهذه الأبيات كلها لرجل من أكبر زعماء الخوارج اسمه: قطري بن

في حين أن الثيعة يرغبون بقاء أنفسهم عبر التاريخ، ويحافظون على

سلامة أنفسهر ما استطاعوا إلى ذلك سبيلاً (1).

والحقيقة كما يبدو أن خلاف الخوارج لم يشتد ولم يأخذ شكثه الحاد إلا

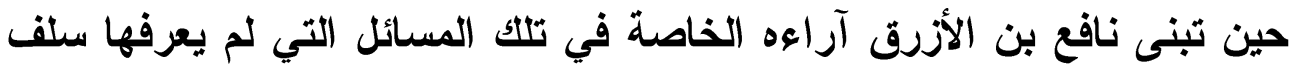
الخوارج ولم يخوضوا فيها بالتفصيل، وحينما أخذ نافع في تطبيقها اعتبرها

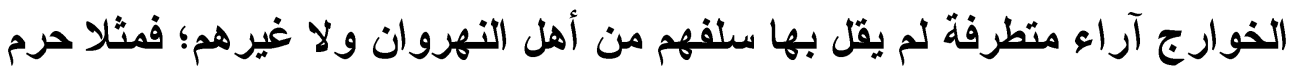

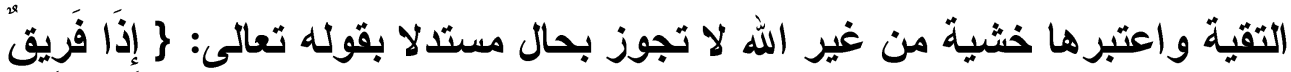

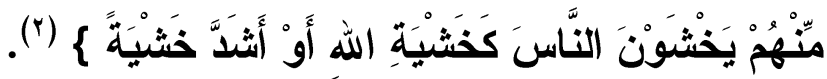
وعلى هذا فإن القعدة الذين بستندون إلى التقية غير مؤمنين في نظره،

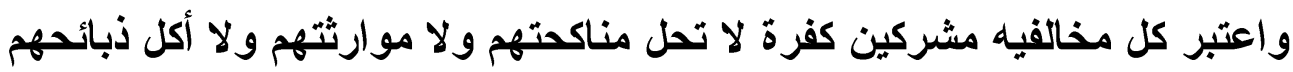
ولا يجب رد أماناتهم إليهم. ويحل أيضا قتل نسائهم وأطفالهم كما قال تعالى: كولَا

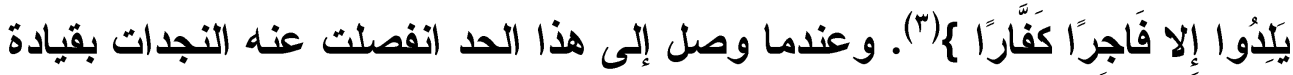

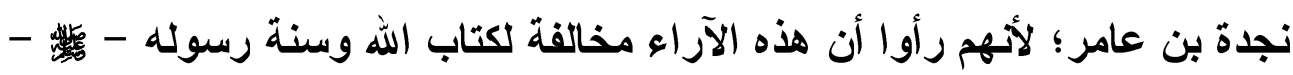

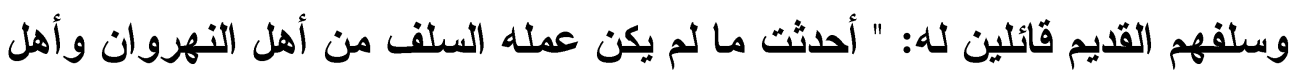

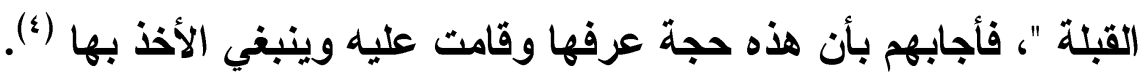

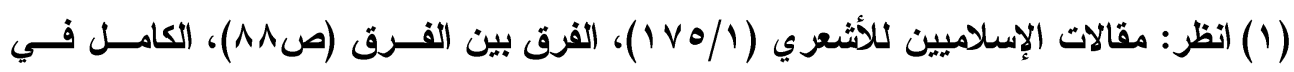

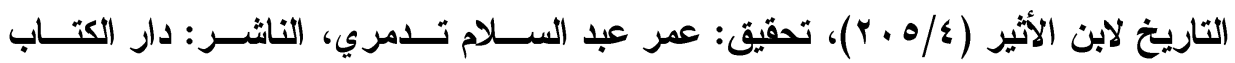

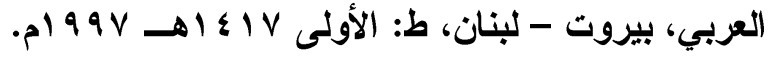

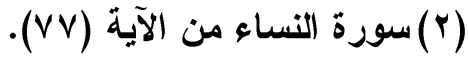

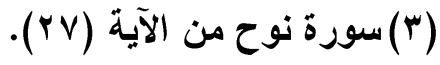

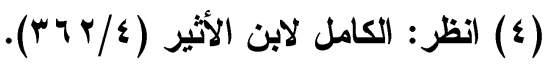


قال عبد الرحمن النجم: " إن الآراء الثديدة الغاية التي تبناها نافع بن الأزرق وضعت الخوارج في بداية مرحلة خطيرة، فقد فتحت مجالا واسعا أمام مجتهديهم لمناقشات نظرية واسعة استمرت فترة من الزمن وأدت إلى ظهور آراء متباينة ومواقف مختلفة وكاتت سببا في تفرقهم، ولا ريب أن الاتجاه المعتدل الأي يمثله النجدات هو أقرب إلى آراء عامة المسلمين " (")، وابن عبد ربه يرى أن الخوارج قبل وجود نافع بن الأزرق كانوا لا يختلفون إلا في الثيء الثاذ حتى جاء نافع فأوجد فجوات بينه؛ يقول ابن عبد ربه: " الأزارقة أصحاب نافع بن الأزرق الحنفي وكانوا قبل على رأي واحد لا يختلفون إلا في الشيء الثاذ " (؟ّ). ومهما يكن من اختلاف العلماء حول تحديد أول من أحدث الافتراق بين

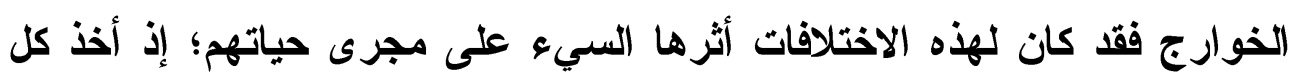
فريق منهم يشنع على مخالفيه قوله.

عن أن الخوارج إنما هم الذين ابتدعوا مصطلح دار التقية ودار العلاتية، وأن دار مخالقيهم إنما هي دار كفر، وكانوا يعنون بدار التقية: المواطن التي يغلب عليها غيرهم من المسلمين، فبينوا لنا مدى اضطرارهم إلى التعلق بهذا الارع، الأي حمى كثيرا " من المسلمين قبلهم وبعدهم، بل لق كان من لصوق إنى التقية بالخوارج، أنهم - مع اعتبارهم أن غيرهم من المسلمين كفارا " - جوزوا هن هن

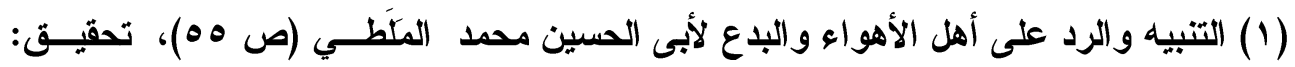

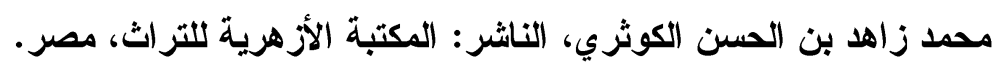

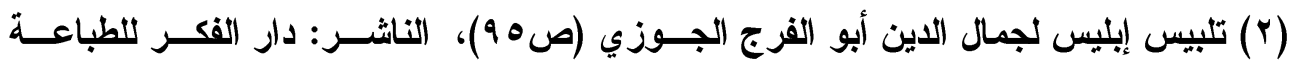

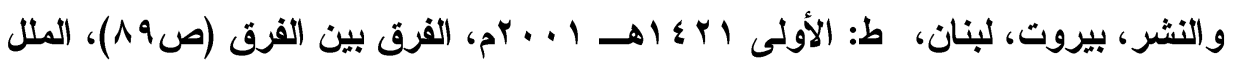

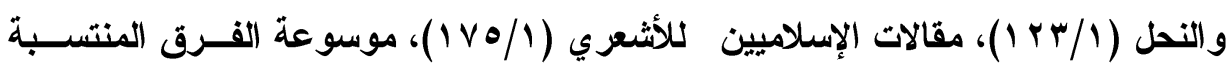

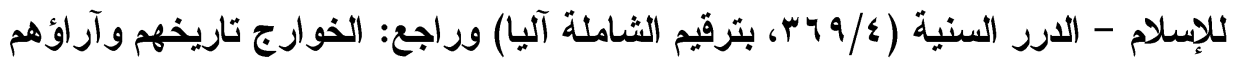
الاعتقادية وموقف الإسلام منها لغالب عواجي (ص لـ ـ 9 (1).

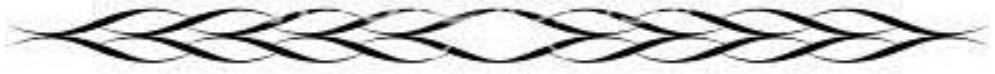


تزويج المسلمات - أي الخارجيات - من كفار قومهم - أي المسلمين ذوي المذاهب الأخرى - في دار التقية .

ولعل هذا إنما يعني أنهم - وهم غلاة المخلصين لمبادئهم - إنما قـ سمحوا بالزنا، الأي يعنيه تزويج الكافر بالمسلمة - بقدر ما يتعلق الأمر بعقيدتهم

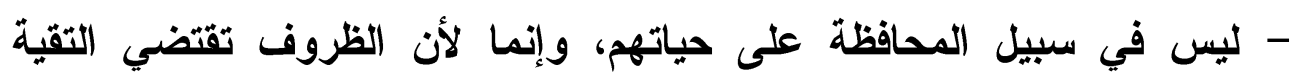
و الكتمان، هذا فضلا " عن أن للصدقات عندهم تنظيم خاص، يختلف في حال التقية عنه في حال العلانية.

ومع ذلك، فإن هذا لا يعتنقه كل الخوارج، ولكنه الرأي المشهور من كثير من فرقهم، وقد التزم به النجدات والإبراهيمية والضحاكية والإباضية،

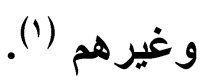

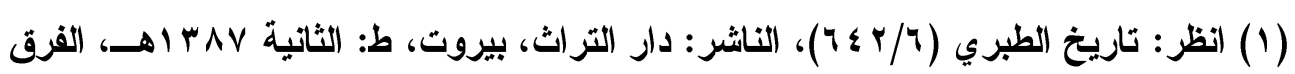

$$
\text { بين الفرق للبغدادي (ص ع ^). }
$$


من خلال ما سبق عرضه في المبحث السابق تبين أن الخوارج قـ انقسموا حول التقية إلى أربعة أقسام القسم الأول منعوا التقية ونددوا بمن يعمل بها بثدة وكفروا القاعدين عن القتال، والقسم الثاني فقد أجازوا التقية في القول والعمل ولو أدى ذلك إلى قتل النفس التي حرم الله ـ والقسم الثالث فكانوا وسطا بين هؤلاء وهؤلاء فأجازوها في القول دون الفعل والقسم الرابع توقفوا فيها و أقو الهم وأدلتهم قابلة للمناقشة. فإننا عندما ننظر إلى موقف اهل اهل السنة من هذه الآراء نجد ان التقية ليست كما قالت الخوارج فهي ليست ممنوعة منعا مطلقا كما ذهب بعض الخوارج وليست جائزة جوازا مطلقا كما ذهب البعض وليست بجائزة في الأقوال دون الأفعال كما ذهب البعض الأخر بل إن التقية عند أهل السنة شيء محظور أجازها الثرع للضرورة ولكن جوازها مقيذ بشروط معينة في أحوال محددة حددها الثرع ولذلك فأهل السنة يرون أن التقية رخصة أباحها الله بشروطها لمن احتاج إليها، فقد أباح الإسلام 》التقيّةةه وهى أن يتقى المسلم أذى أنى المشركين بكلمة أو فعل، ليدفع عنه أذاهم، دون أن ياخل من ذلتك شىع على قلبه وما انعقد عليه من إيمان، فهي حالة اضطرارية خلاف الأصل ألجأت إليها الضرورة والحاجة الثديدة وفى هذا يقول الله تعالَى: \} مَنْ كَفَرَ بِالَّهِهِ مِنْ بَعْدِ

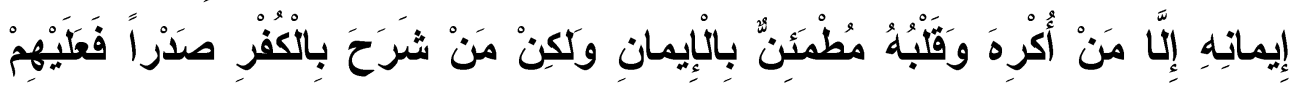

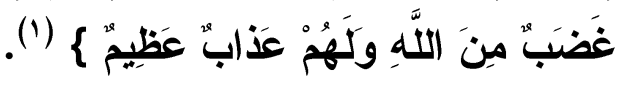

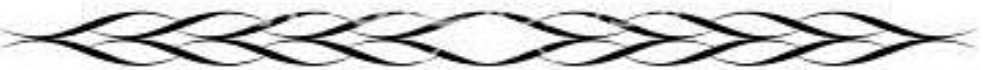


وهذا يعنى أن 》التقيّةهة وإن كانت بابا من أبواب التيسير والرحمة بالمؤمنين، إلا أنها باب محفوف بالمخاطر، لا يدخله الإنسان إلا على حذر ابل و إثففاق، وإلا ريثما يمسك نفسه من التّف.. فإن هذه حال لا ينبغى أن يركن إليها المؤمن، أو يطمئن إلى مقامه فيها.. إذ هو يلبس فيها ثوب النفاق ظاهرا .. و ولا يجتمع إيمان ونفاق.

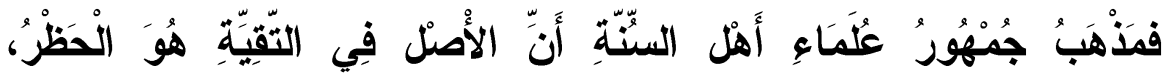

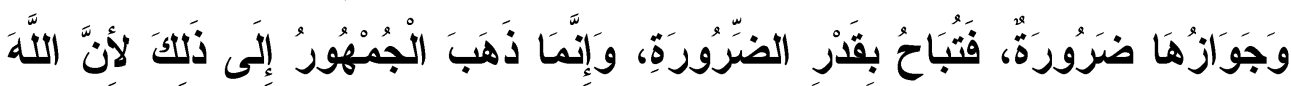

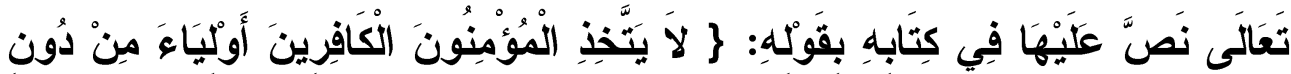

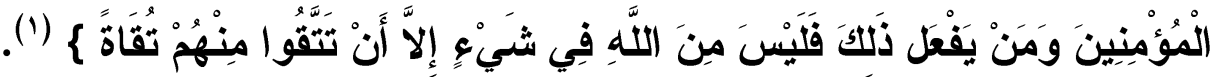

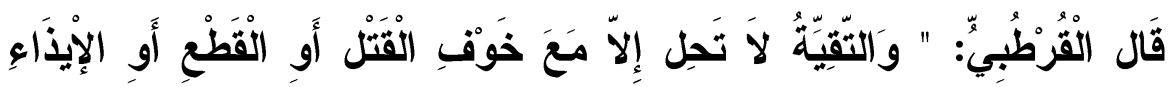

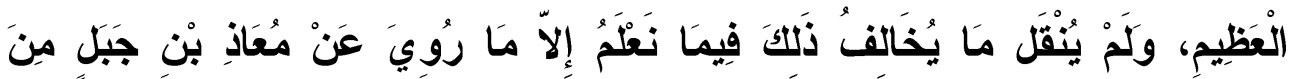

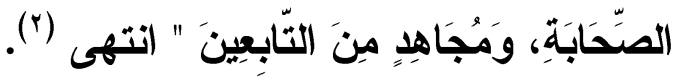
قال ابن القيم : " التقية أن يقول العبد خلاف ما يعتقده لاتقاء مكروه يقع

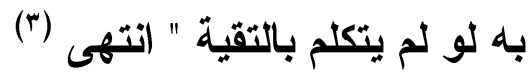

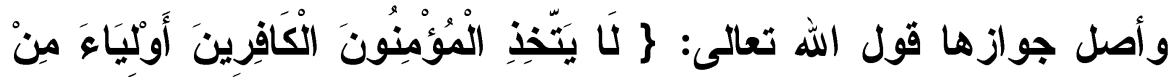

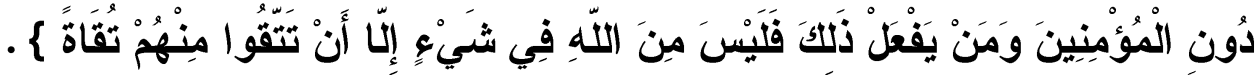

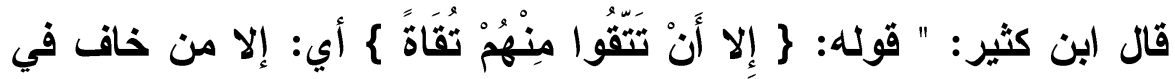
بعض البلان أو الأوقات من شرهم، فله أن يتقيهم بظاهره لا بباطنه ونيته؛ كما بـا

$$
\begin{aligned}
& \text { (1) سورة آل عمران من الآية (Y^). }
\end{aligned}
$$

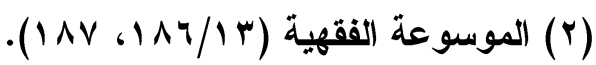

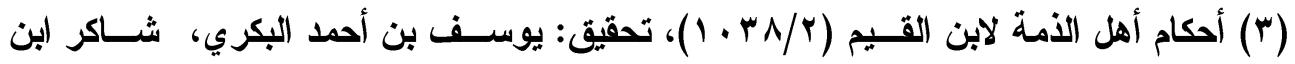

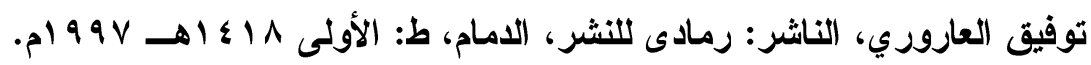




\section{د. فتحي محمود محمد عبد الرحمن}

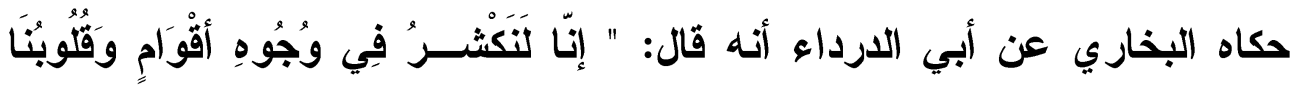

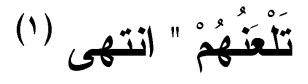

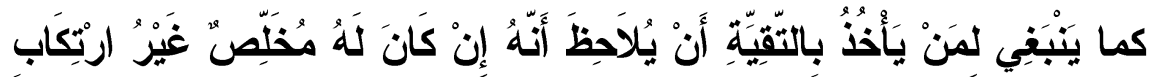

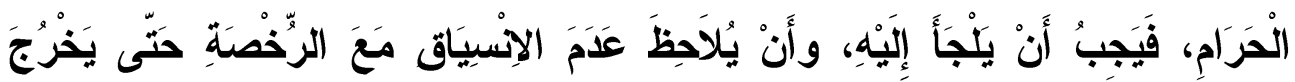

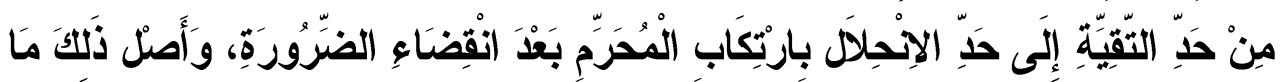

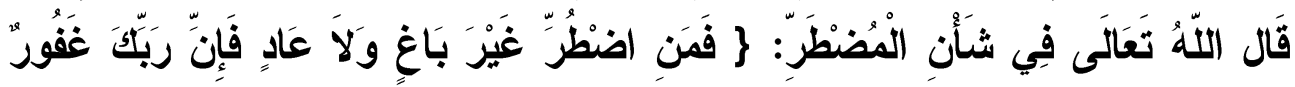

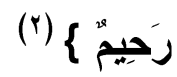

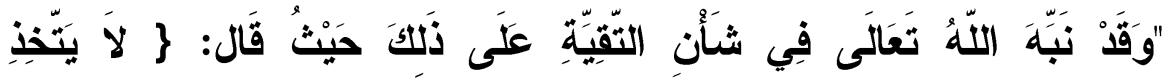

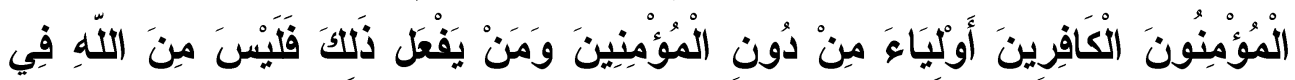

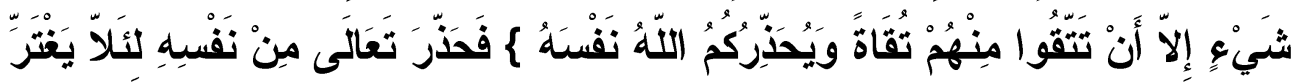

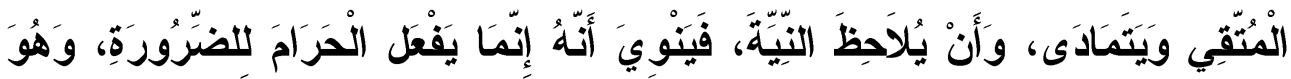

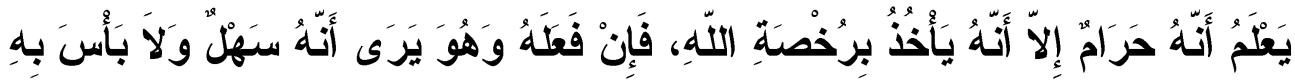

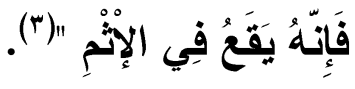

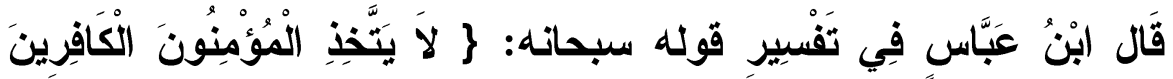

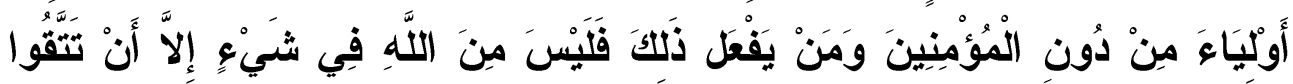

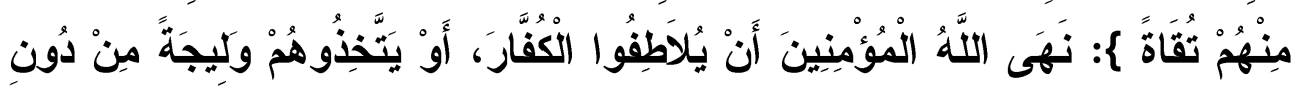

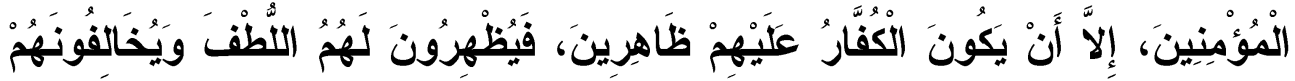

فِي الديّين (؛).

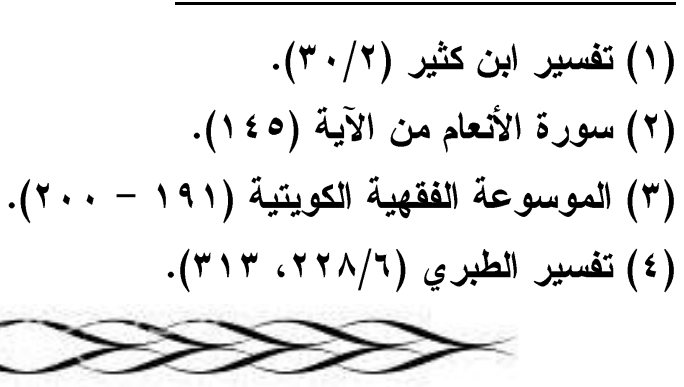




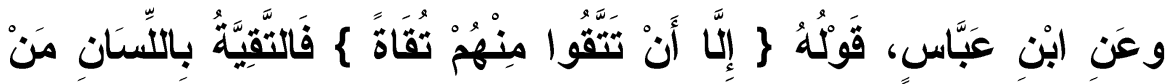

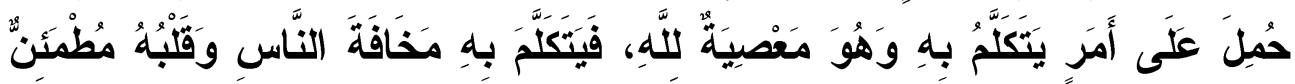

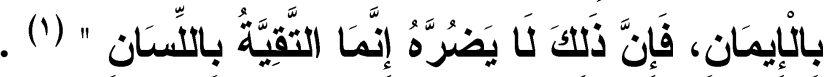
فابن عباس - ب -: جعل التقية أن يتكلم بلسانه وقلبه مطمئن بالإيمان،

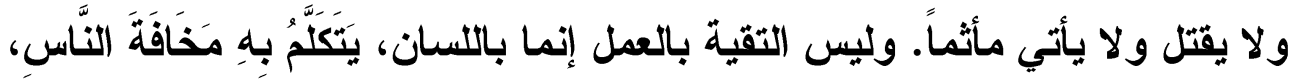

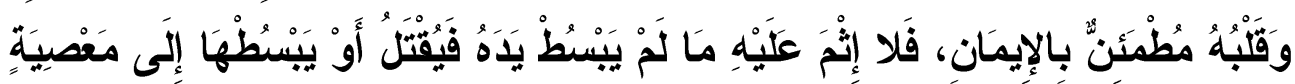

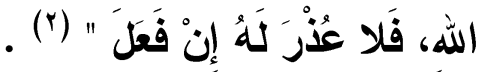

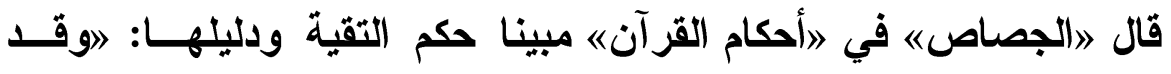

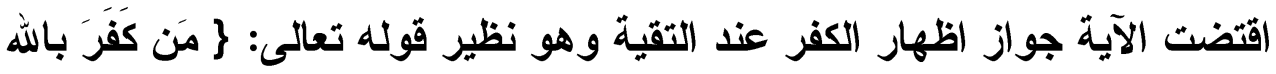

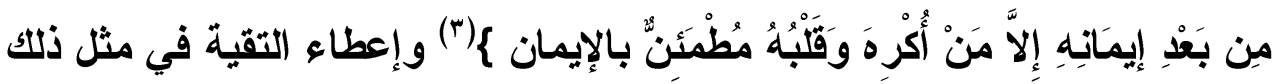

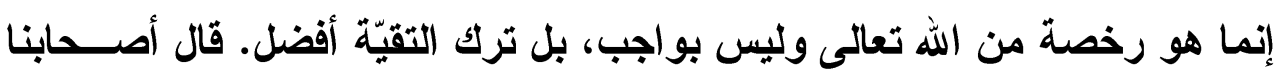

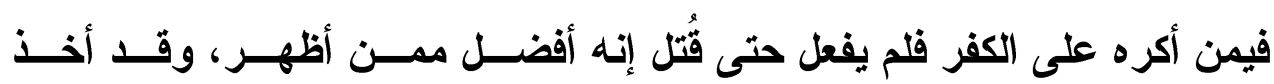

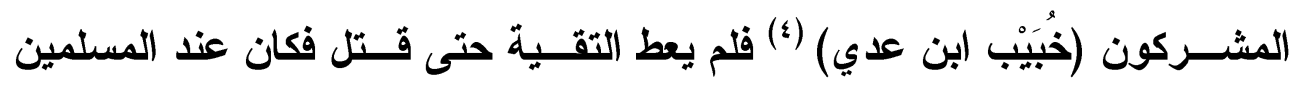

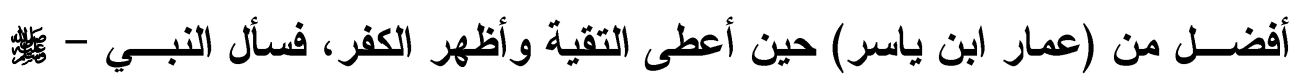

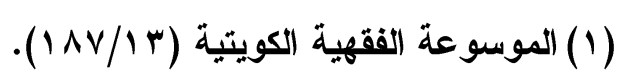

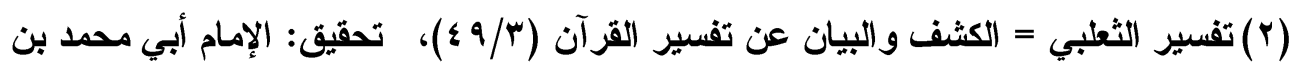

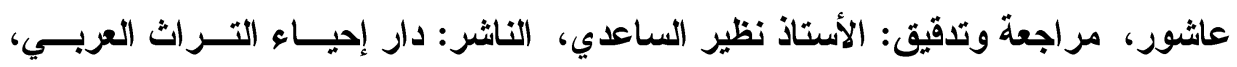

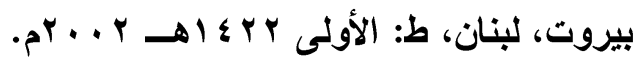

$$
\begin{aligned}
& \text { (ץ) سورة النحل من الآية (؟ 1). }
\end{aligned}
$$

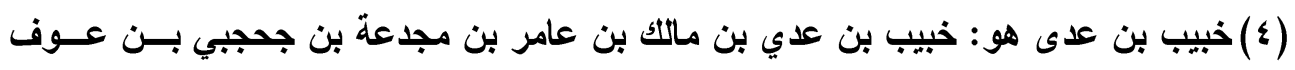

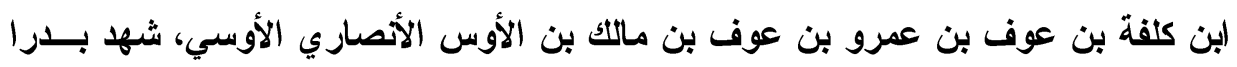

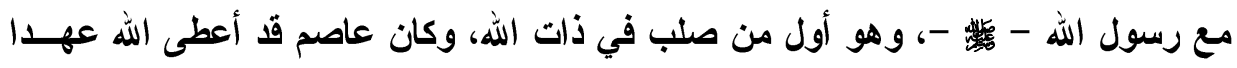

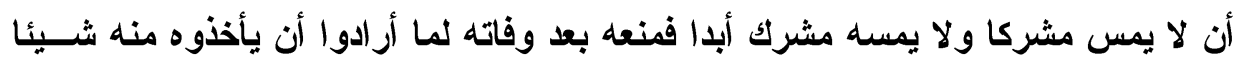

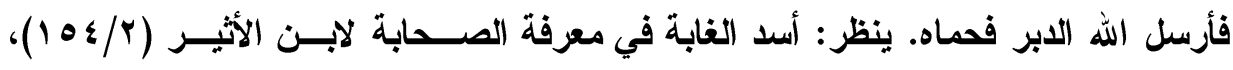

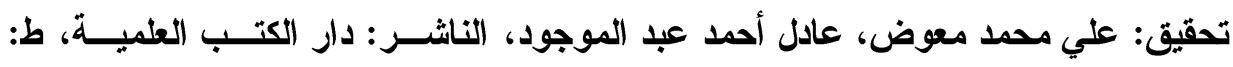




\section{د. قتحي محمود محمد عبد الرحمن}

- عن ذللك، فقال كيف وجدت قلبك ؟ قال: مطئمناً بالإيمان، فقال عادوا فعد ... «"(') وكان ذلك على وجه الترخيص"(؟).

قصة مسيلمة الكذاب مع بعض الصحابة روي أن مسيلمة الكــذاب أخـــ

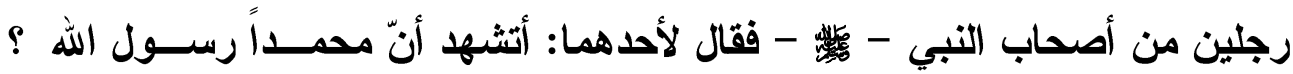
قال: نعم، قال: أتثهر أني رسول الله ؟ ج قال: نعم، فترك سبيله، ثم دعـــا بــالآخر ،

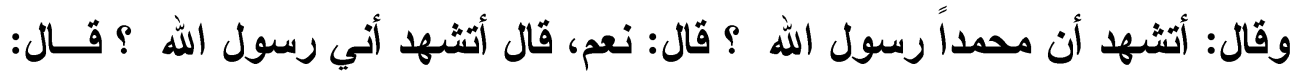

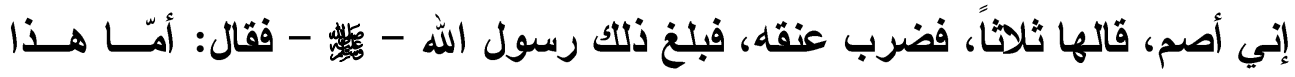
المقتول فمضى على صدقه ويقينه وأخذ بفضيلة فهنيئاً له، وأما الآخر فقبل رخصة

الله فلا تبعة عليه (").

وقد أُبــح الكذب في إظهار الكفــر في التقـية، وكل ما روي عن

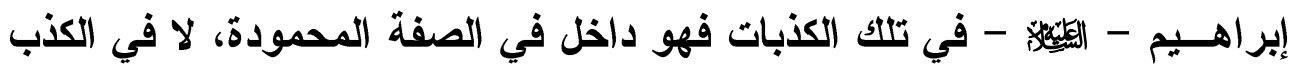

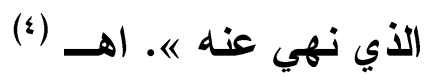

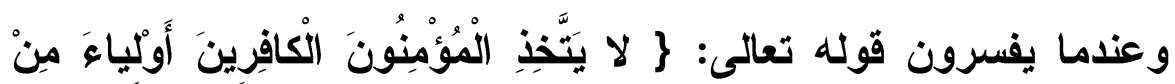

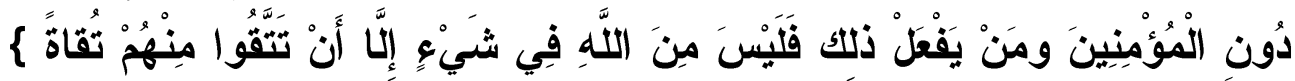
(يقولون): "في هذه الآيات دليل على جواز التقية عند الخوف على النفس وفي كل الأحوال وربما تكون واجبة في بعضها"(ه). حيث يذهب بعضهم إلى الوجوب فيقول

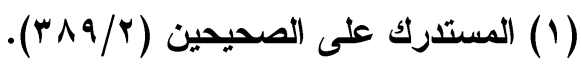

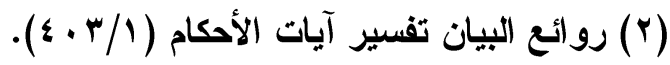

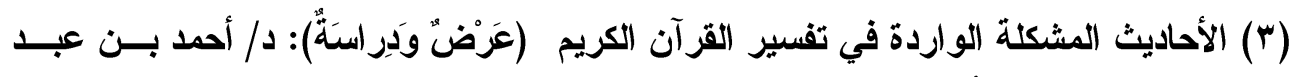

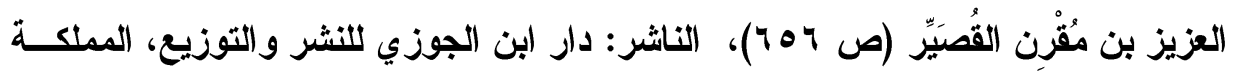

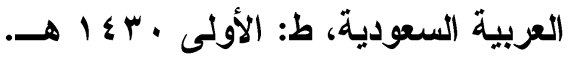

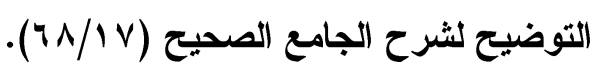

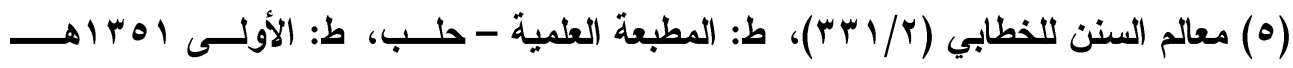


بوجوبها في بعض الحالات ومنهم الغزالي حيث يقول في ذللك: "إن عصمة دم المسلم واجبة فمهما كان القصد سفك دم مسلم فالكذب فيه واجب" (') .

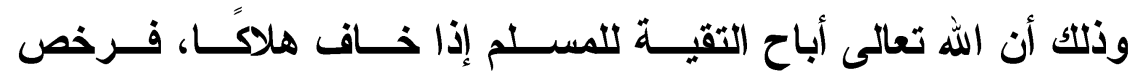

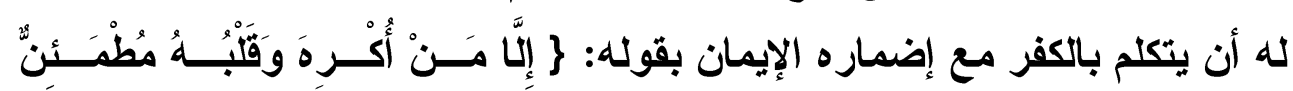

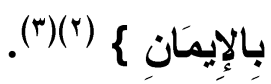

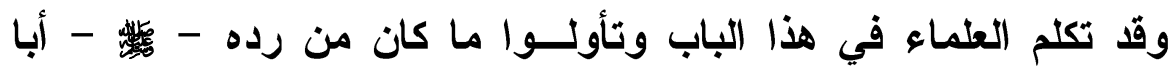
جـندل ابن سهيل() إليهم على وجهين أحدها أن الله تعالى قد أباح التقية للمسلم إذا خاف الهلاك على نفسه ورخص له أن يتكلم بالكفر مع التورية وإضمار الإيمان في رده إليهم إسلاماً له للهلاك مع وجوده السبيل إلى الخلاص منه بما رخص لله فيه من التقية.

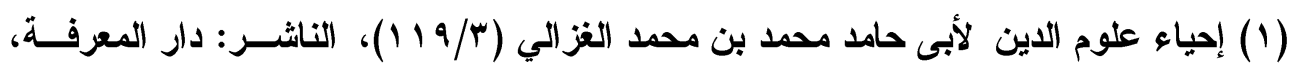
بيروت.

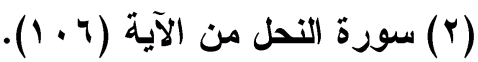

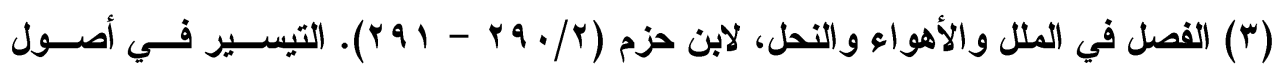

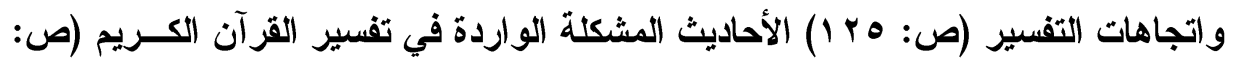
.

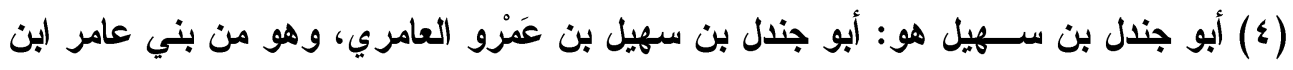

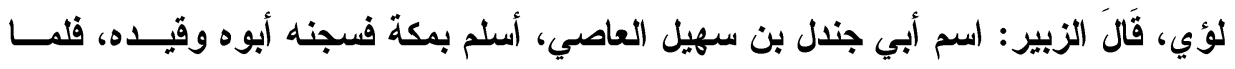

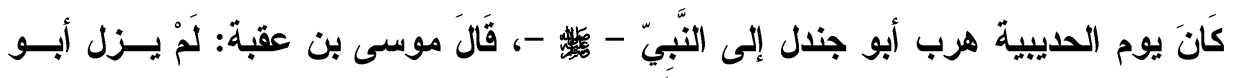

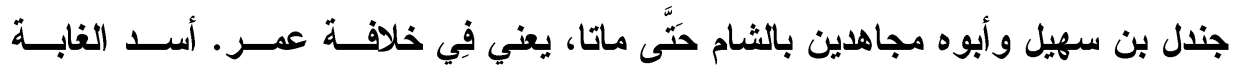

\section{0}




\section{د. قتحي محمود محمد عبد الرحمن}

والوجه الآخر أنه إنما رده إلى أبيه ومعلوم أن أباه لا يقتله ولكن يستبقيه وينتظر به الرُجعي وفي ذلك أمان له وصلاح لعامة المسلمين ودرك لما راموه في عقد الصلح وقصدوه من البغية فيه(').

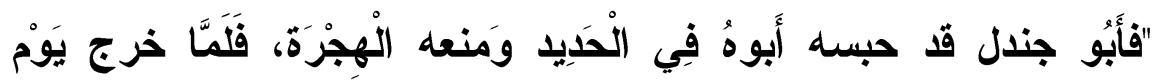

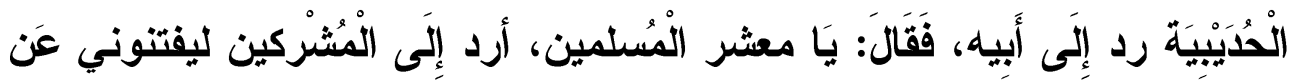

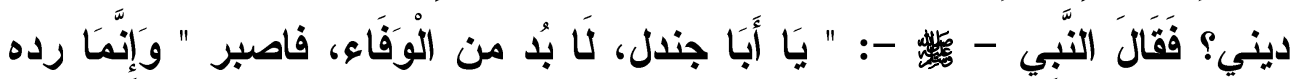

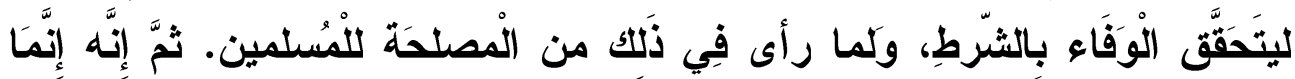

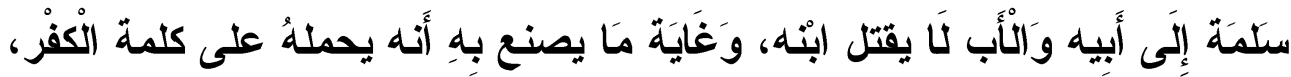

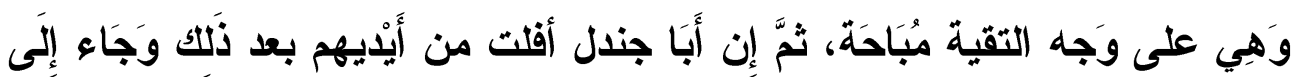

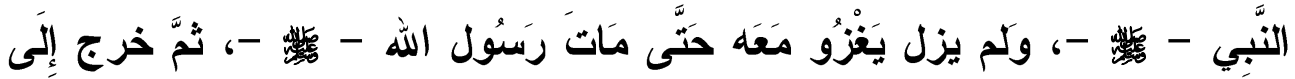

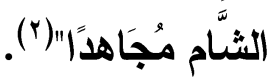

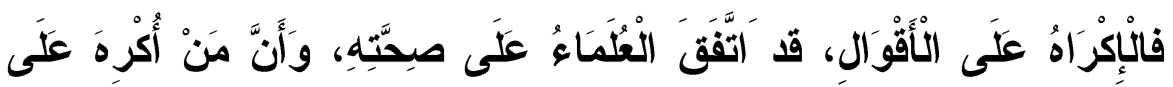

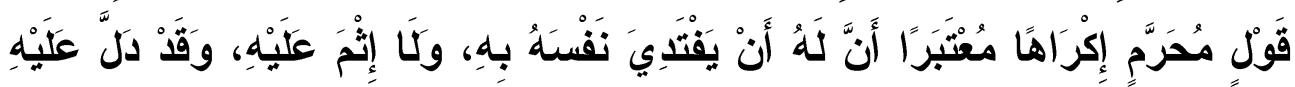
قَوْلُ اللََّّهِ تَعَالَّى $\}$

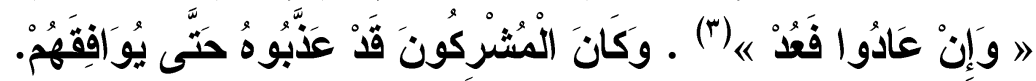

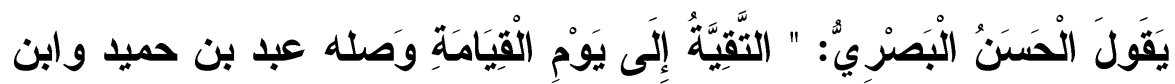

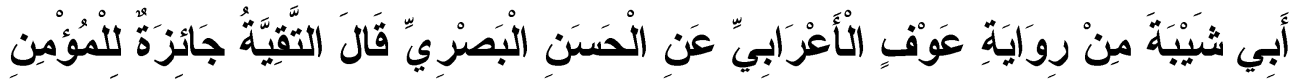

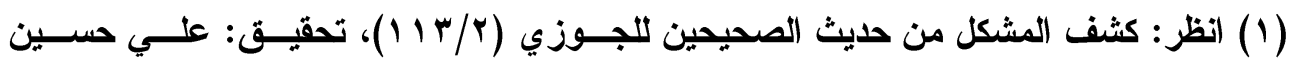
البواب، الناشر : دار الوطن - الرياض.

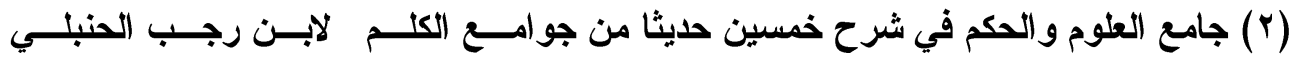
(rVY/r)

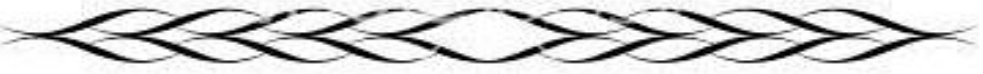




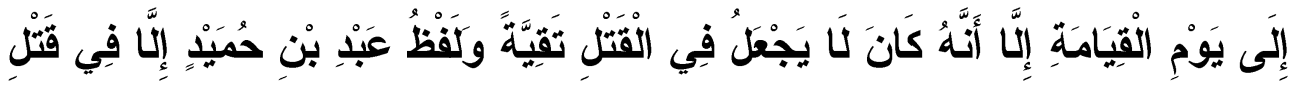

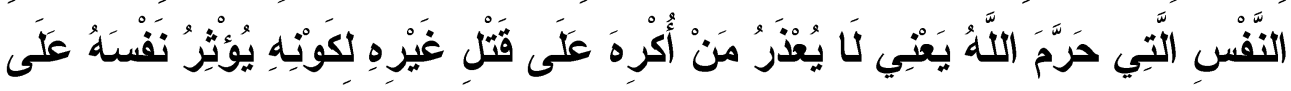

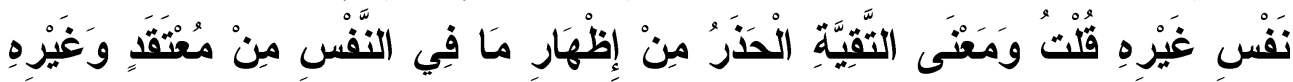

لَنْيَرْ "(1)

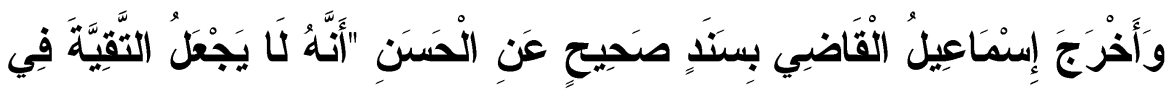

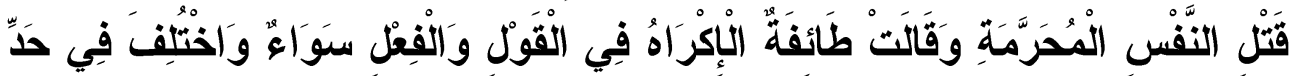

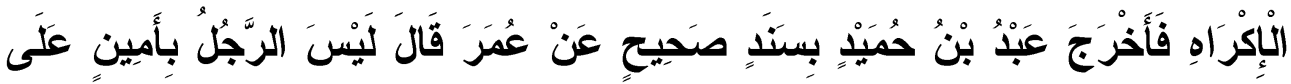

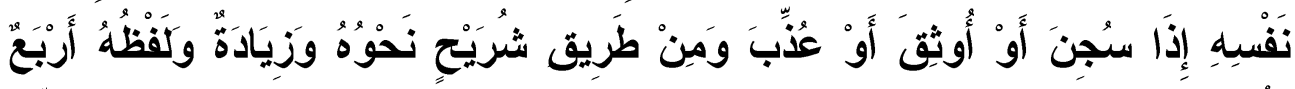

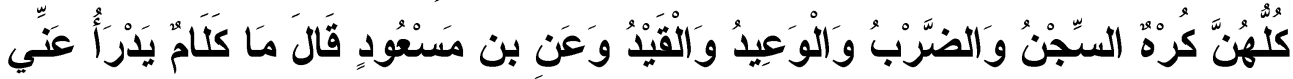

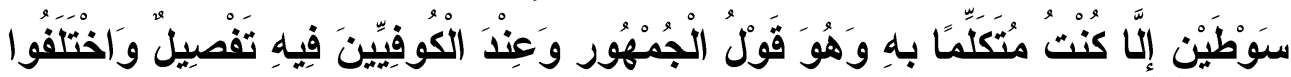

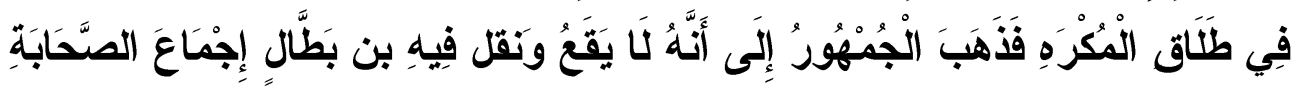

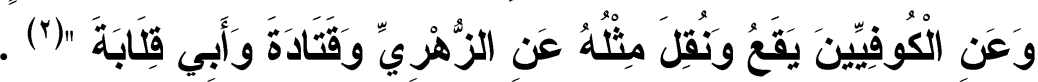

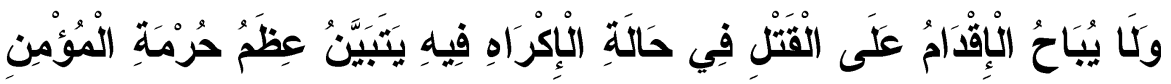

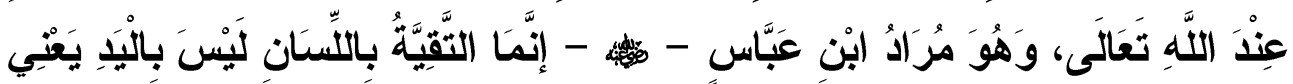

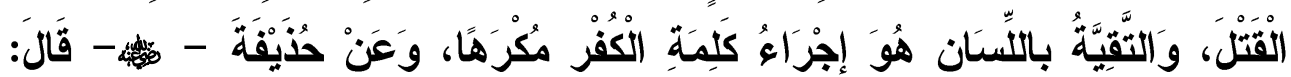

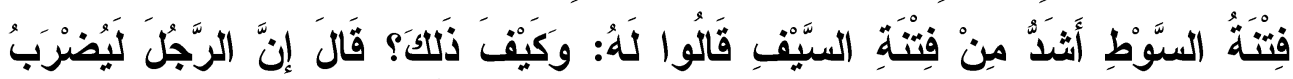

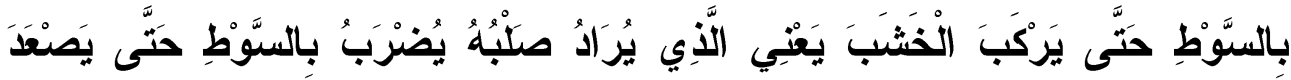

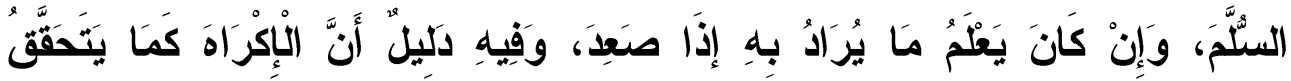

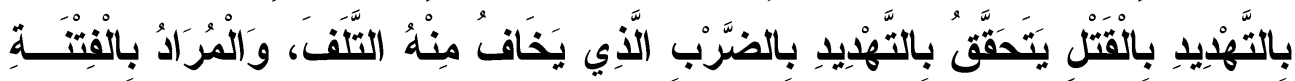

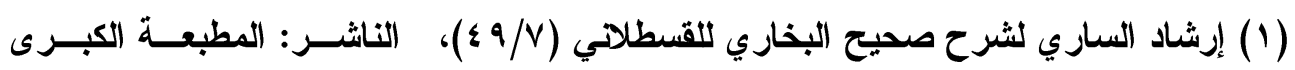

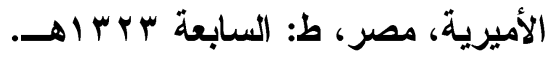

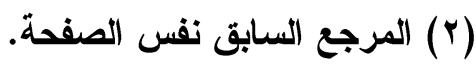

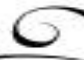




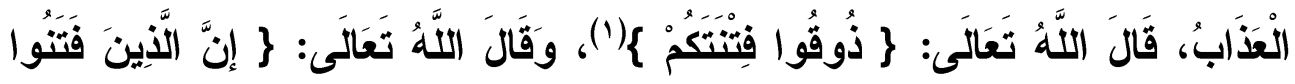

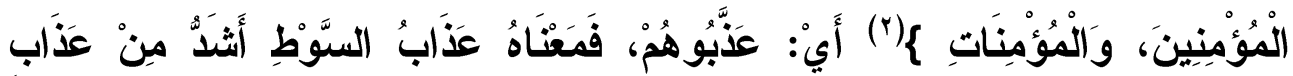

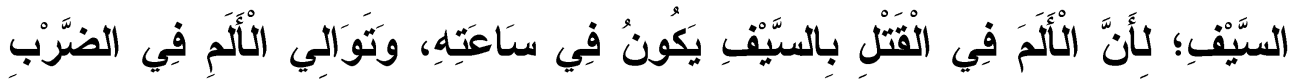

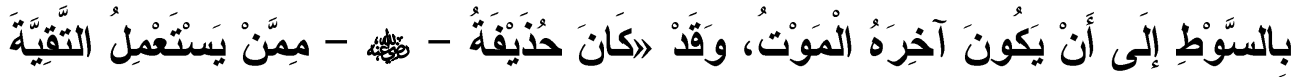

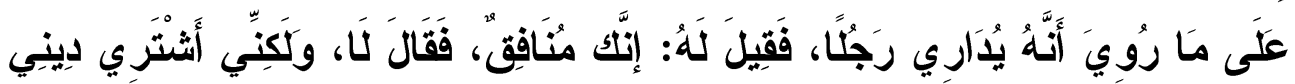

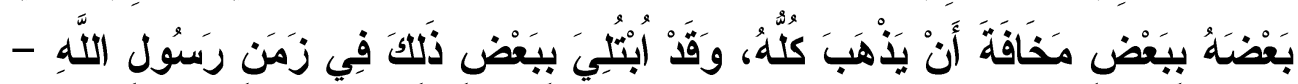

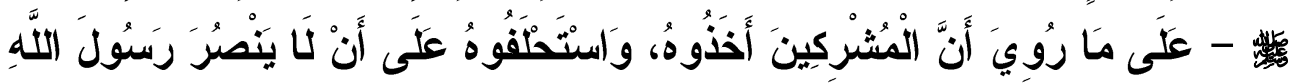

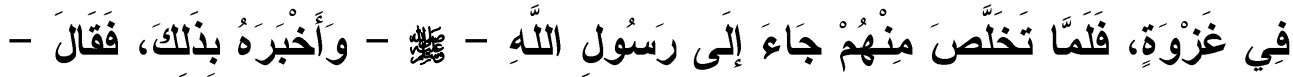

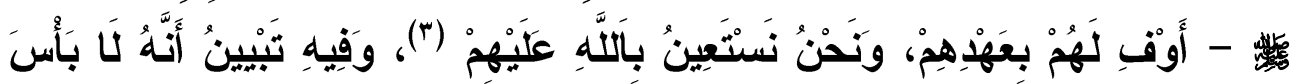

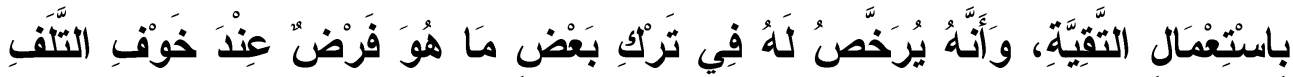

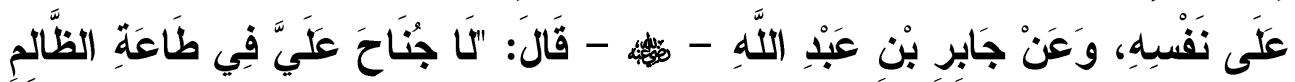

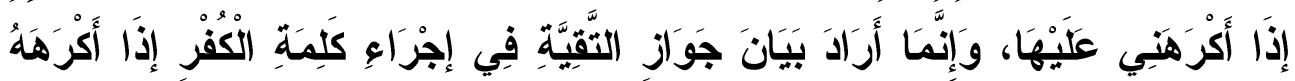

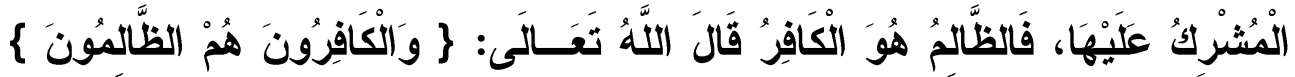

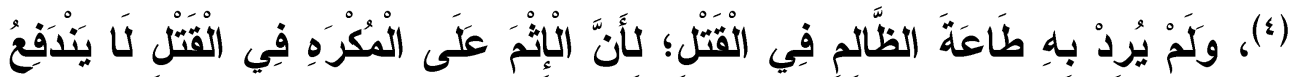

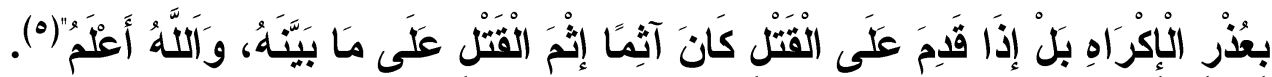

$$
\text { (1) سورة الاريات من الآية (ع (1). }
$$

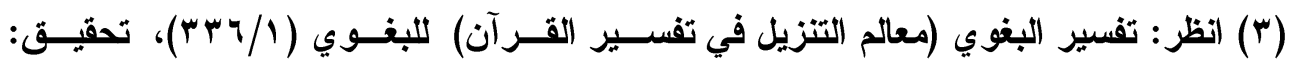

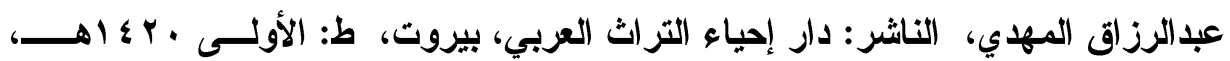

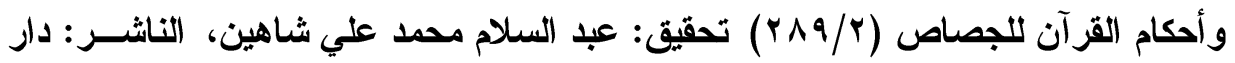

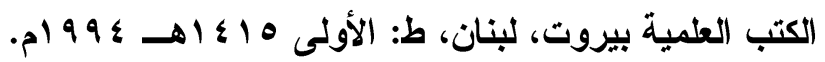

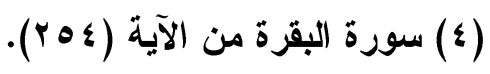

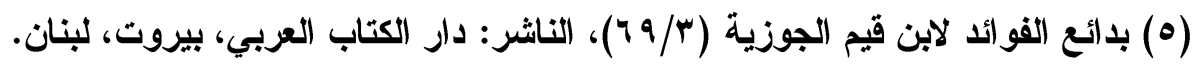


وقال أبو عبد اللَّه القرطبيّ بعد ذكر نحو ما تقدّم. وقال النخعيّ: "القيد إكراه، والسجن إكراه. وهذا قول مالكك، إلا أنه قال: والوعيد المخوّف إكراه، وإن لم يقع، إذا تحقّق ظلم ذلك المتعدّي، وإنفاذه لما يتوعّد به، وليس عند مالك وأصحابه في الضرب والسجن توقيت، إنما هو ما كان يؤلم من الضرب، وما كان من سجن ياخلُ منه الضيق على المكره. و إكر اه السلطان وغيره عند مالك إكر اه. وتناقض الكوفيّون، فلم يجعلوا السجن، والقيد إكراهًا على شــرب الخمــر، و أكل الميتة؛ لأنه لا يُخاف منهما التلف، وجعلوهما إكراهًا في إقراره لفلان عنــــي ألف درهم. قال ابن سُحنون: وفي إجماعهم على أن الألم، والوجع الثديد إكراه مـــا

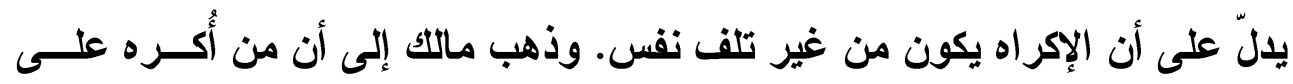

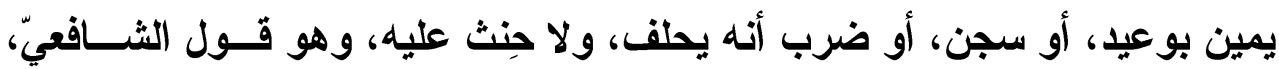

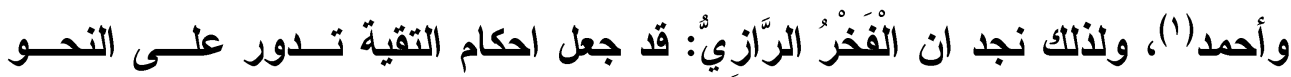
التالي: - n

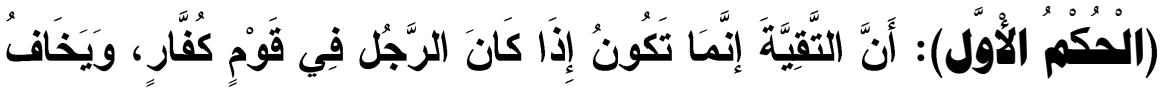

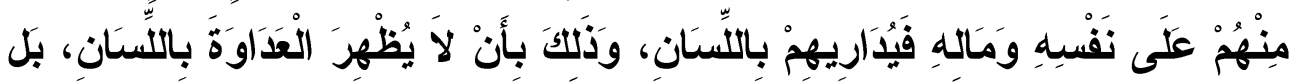

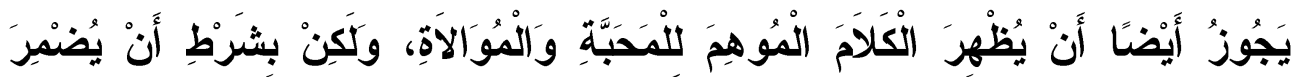

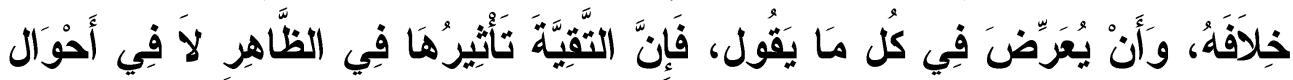
الْقُوب.

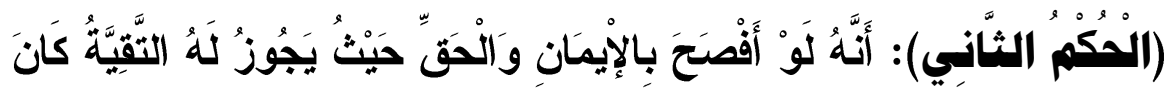

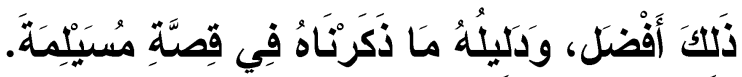

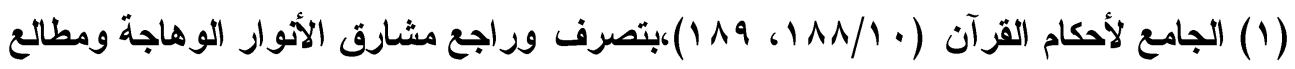

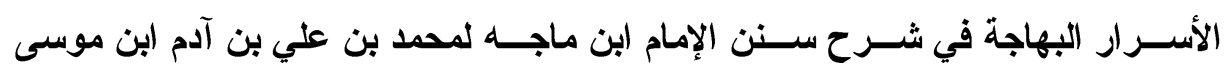

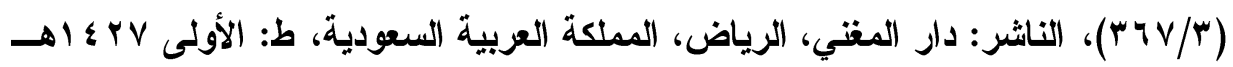




\section{د. فتحي محمود محمد عبد الرحمز}

" $1 \wedge V$ ?

التقية

عند الخوارج وموقف أهل السنة منها

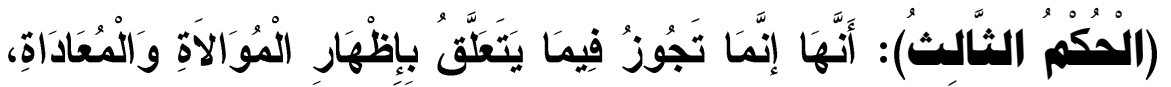

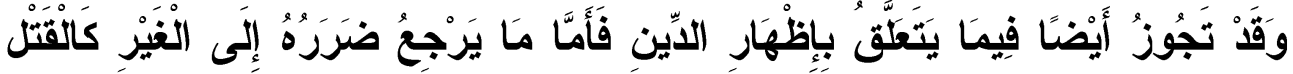

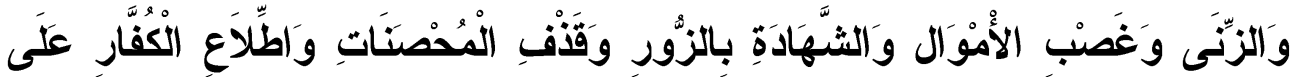

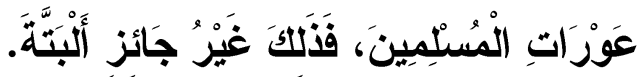

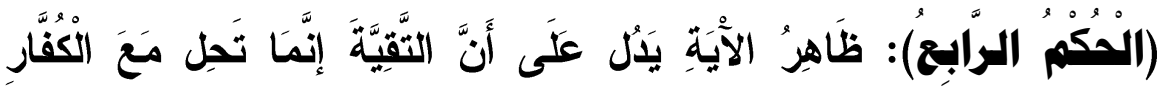

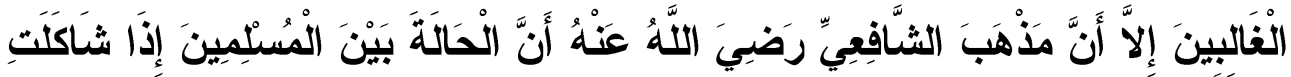

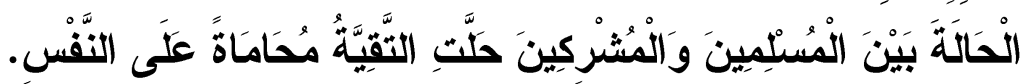

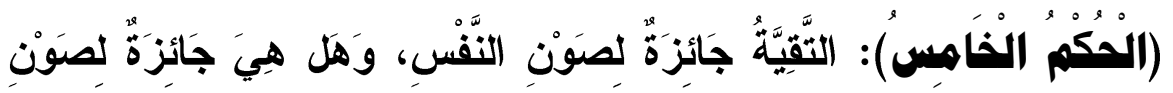

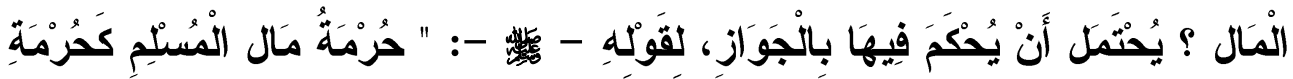

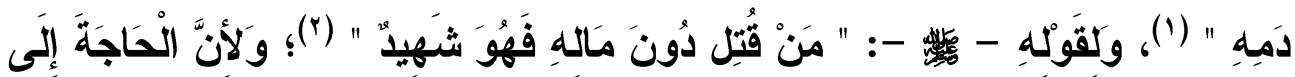

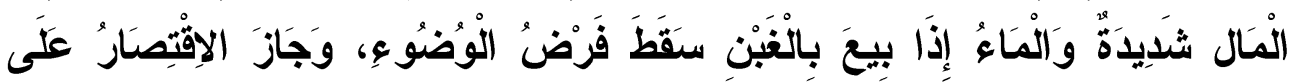

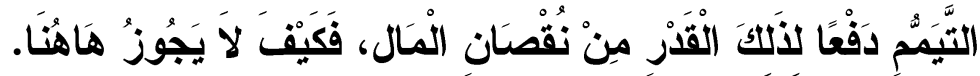

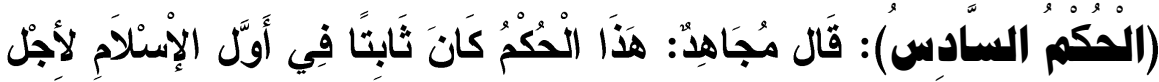

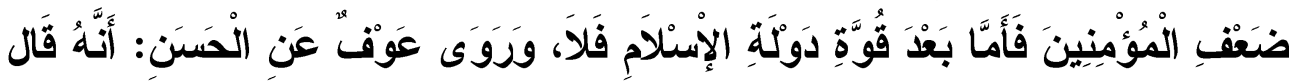

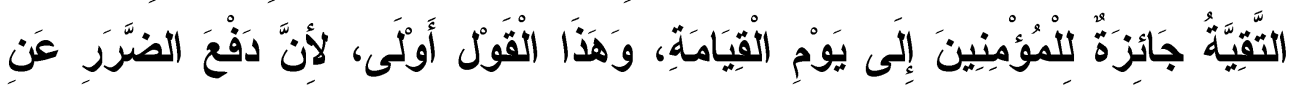

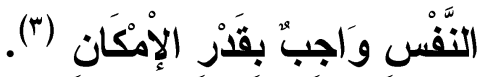

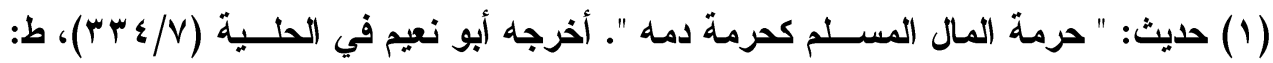

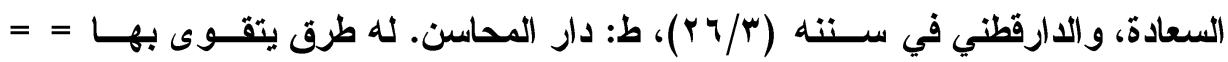

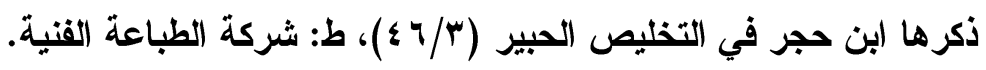

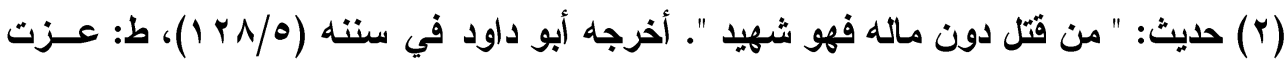

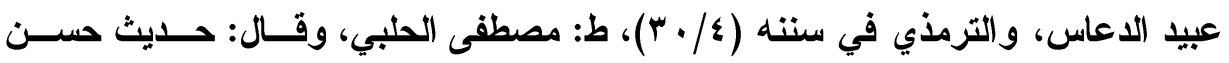

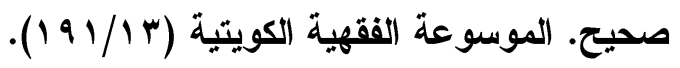

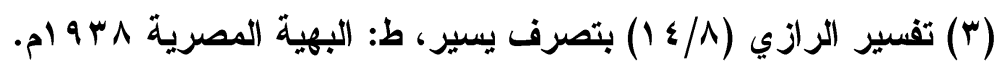


يقول ابن رجب في فتح الباري: " هذا مع أن التقية في ذلك باللسان جائزة

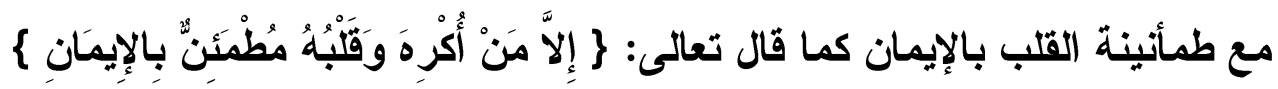

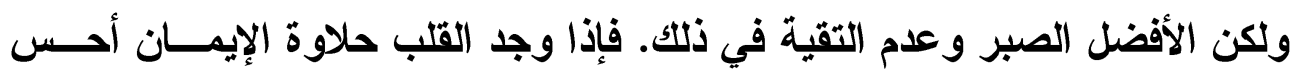

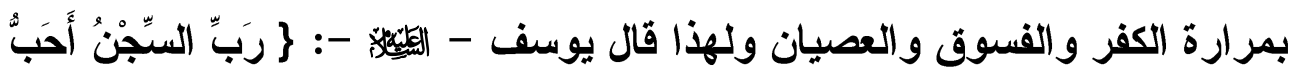

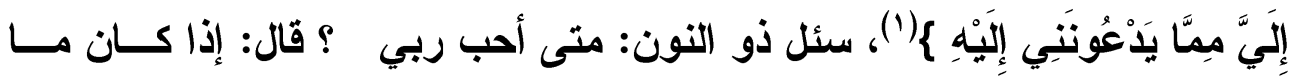

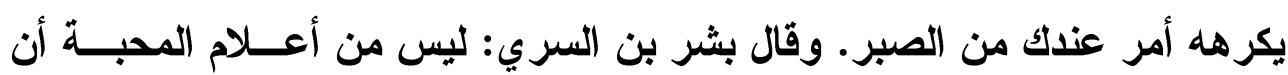

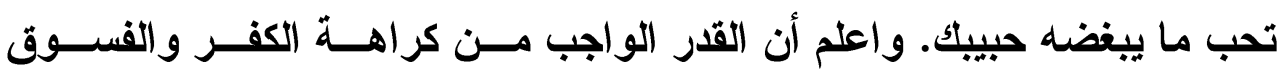

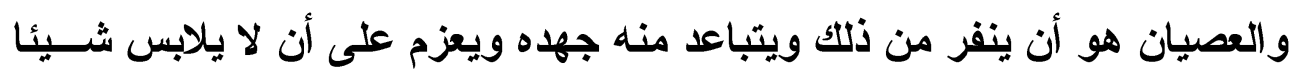

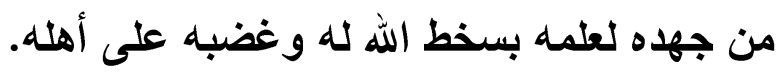

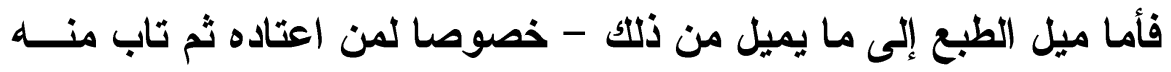

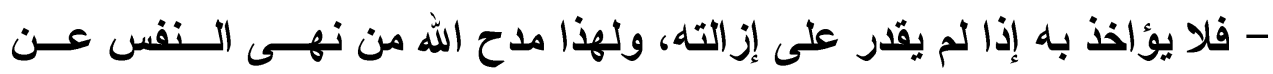

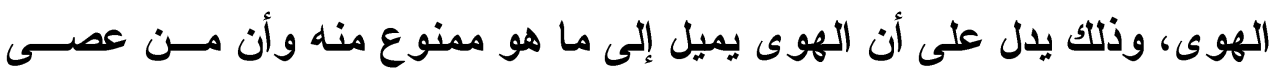

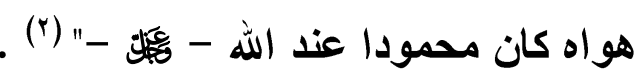

وعد قوم من باب التقية مداراة الكفار و الفسقة والظلمة و وإلانة الكلام لهم

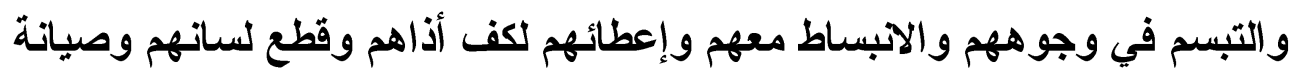

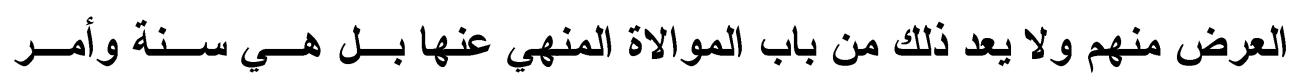

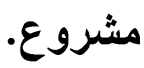

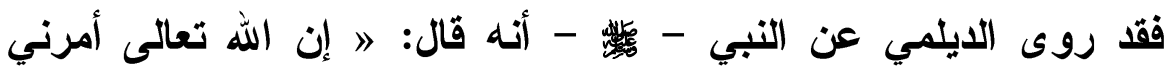

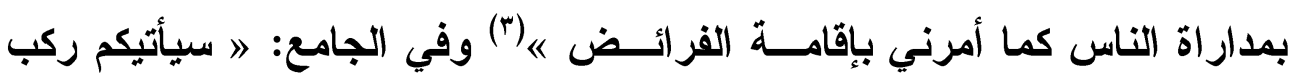

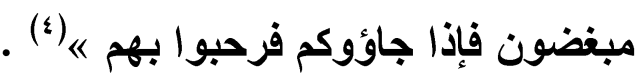

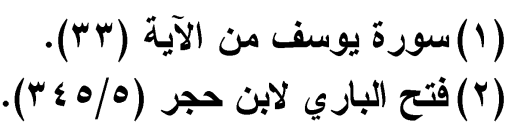

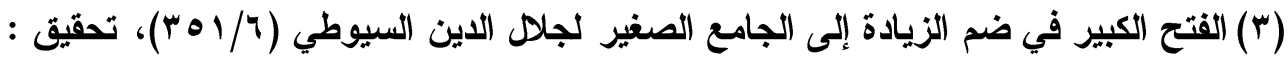

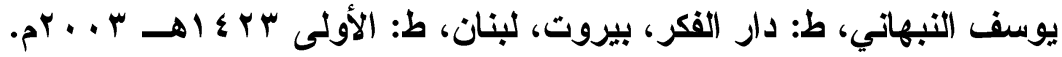

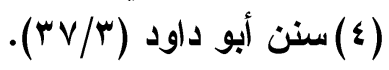


وفي البخاري عن أبي الارداء: 》 إنا لنكشـر في وجوه أقوام وإن قلوبنا

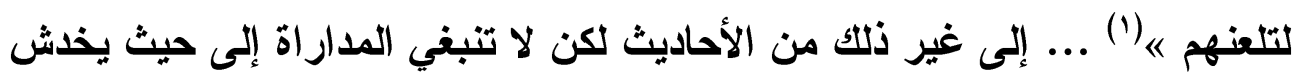
الاين ويرتكب المنكر وتسيء الظنون(؟). ولذلك قال العلاَّمة محمود الألوسي في تفسيره روح المعاني في تفسير

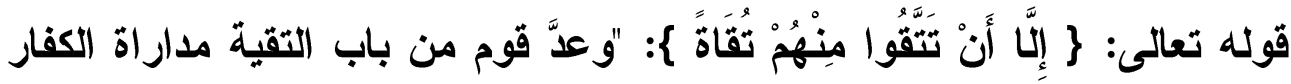
والفسقة والظلمة وإلاتة الكلام لهم والتبسم في وجوههم والآبساط معهم و إعطاءهم لكف أذاهم وقطع ألسنتهم وصيانة العرض منهم، ولا يعد ذلك من باب الموالاة المنهي عنها، بل هو سنة وأمر مشروع". والتقية لا تكون إلا مع خوف

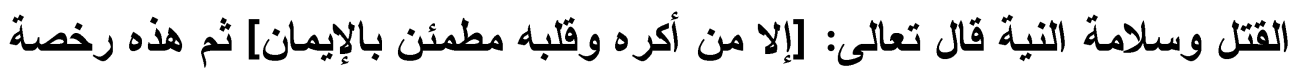
فلو صبر حتى قتل فله أجر عظيم "(") .

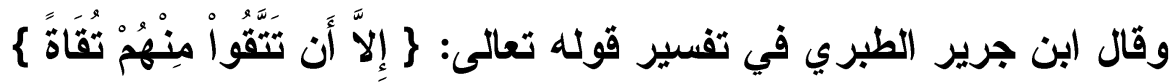
أي: "إلا أن تكونوا في سلطانهم فتخافوهم على أنفسكم فتظهروا لهم الولاية بألسنتكم وتضمروا العداوة، ولا تشايعوهم على ما هم عليه من الكفر ولا تعينوهم

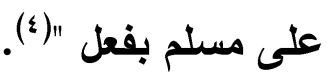

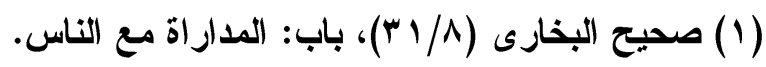

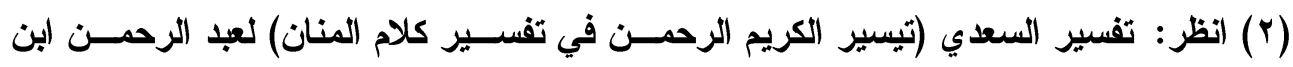

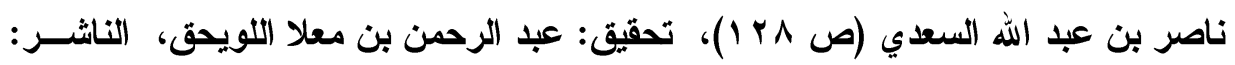

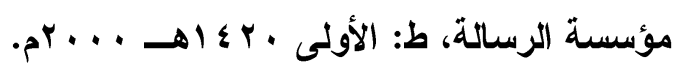

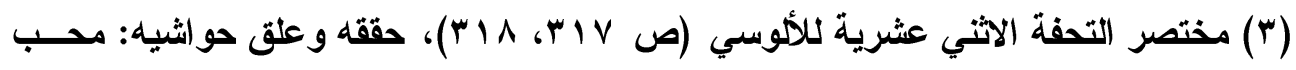

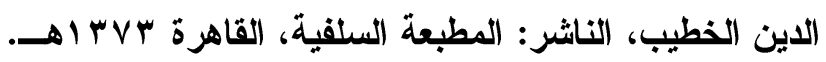

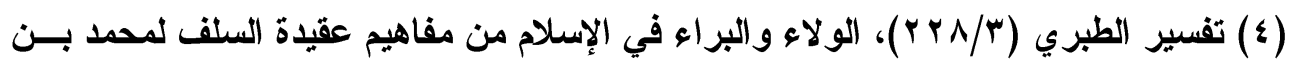

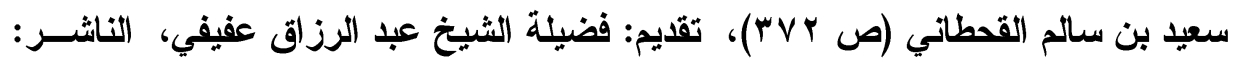

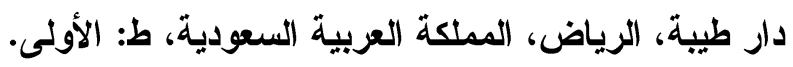

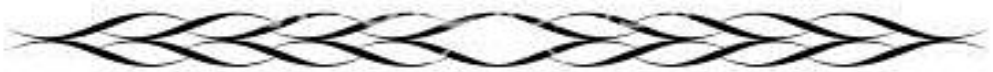


قال بعض أهل العلم هذه الآية تدل على أن من رضي بالكفر .. فهو كافر، ومن رضي بمنكر يراه، وخالط أهله، وإن لم يباشر .. كان في الإثم بمنزلة المباشر، أما إذا كان ساخطًا لقولهم وفعلهم، وإنما جلس على سبيل التقية والخوف، فالأمر ليس كذلك، فالمنافقون الأين كانوا يجالسون اليهود ويطعنون في الرسول والقرآن مع اليهود هم كافرون مثل أولئك اليهود، أما المسلمون الأين كانوا بمكة يجالسون الكفار الأين كانوا يطعنون في القرآن. ـ فإنهم باقون على الإيمان؛ لأنهم إنما يجالسون الكفار للضرورة والتقية منهم، وأما المناققون في المدينة فلا ضرورة لهم إلى الجلوس مع اليهود (1). ويقول الإمام الشنقيطي - I - مبينًا حدود التقية، وكيفية استخدامها:

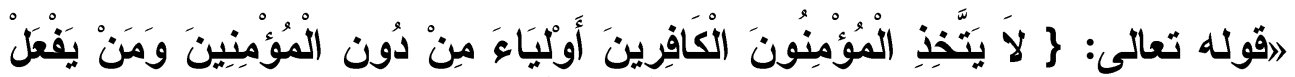

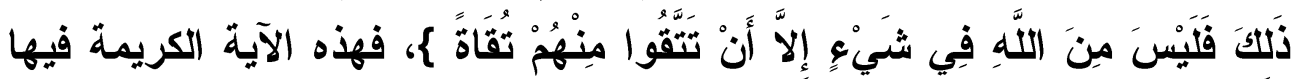
بيان لكل الآيات القاضية بمنع موالاة الكفار مطلقًا وإيضاح، لأن محل ذلتك في حالة الاختيار، وأما عند الخوف والتقية فيرخص في موالاتهم بقدر المداراة التي يكتفي بها شرهم، ويشترط في ذلك سلامة الباطن من تلكك الموالاة. ومن يأتي الأمور على اضطرار ... فليس كمثل آتيها اختيارًا ويفهم من ظواهر هذه الأبيات: أن من تولى الكفار عمدًا اختيارًا، رغبة

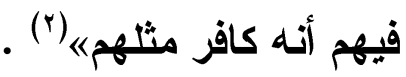

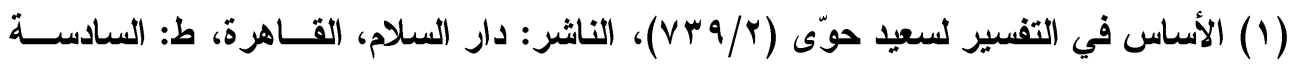
ع (r) أضواء البيان في إيضاح القرآن بالقر آن لمحمد الأمين بن محمد المختار بن عبــد القــادر

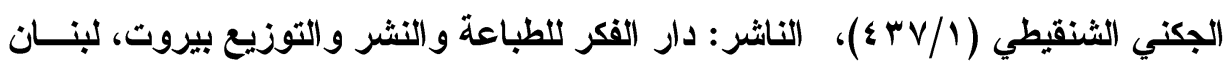
ها أ اهـ هو 99 ام، فتح العلي الحميد في شرح كتاب مفيد المستفيد في كفر تارك التوحيد لمدحت بن الحسن آل فراج (ص آساء)، الناشر: دار الأخيار. 


\section{د. قتحي محمود محمد عبد الرحمز}

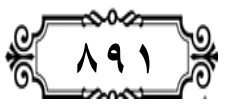

التقية

مند الخوارج وموقف أهل السنة منها

ومما سبق يتضح جواز التقيّة عند الضرّورة، بالتلفّظ بكلمة الكفر، مع

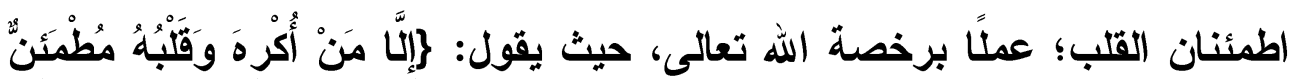

بالَّإيمَان $\{$ (')

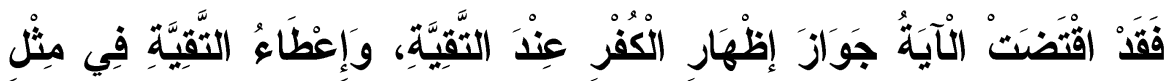

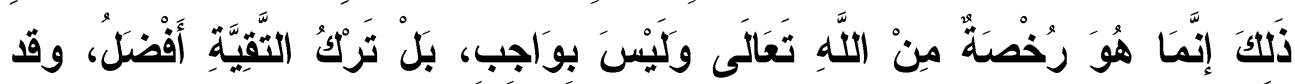

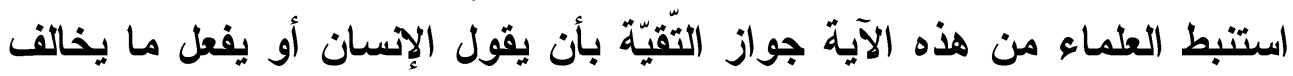
الحق لأجل توقى ضرر من الأعداء يعود إلى النفس أو العرض أو المال.

فمن نطق بكلمة الكفر مكرها وقاية لنفسه من الهلالك، وقلبه مطمئن بالإيمان لا يكون كافر ا بل يعذر كما فعل عمار بن ياسر حين أكرهته قريش على

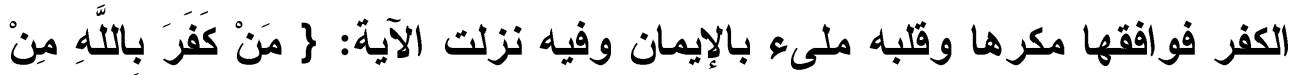

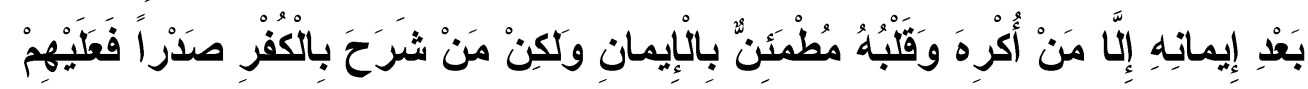

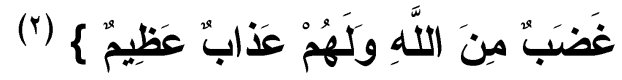

وكما عذر الصحابي الأي قال له مسيلمة: أتثهر أنى رسول الله؟ قال نعم فتركه وقتل رفيقه الأي سأله هذا السؤال فقال: إنى أصمّ (ثلاثا) فقدّمه وقتله، فبلغ ذلك رسول الله - فئدة - فقال: أما هذا المقتول فمضى على يقينه وصدقه فهنيئا له، وأما الآخر فقبل رخصة الله فلا تبعة عليه("). وبذلك يتضح ان التقية من الرخص لأجل الضرورات العارضة، لا من أصول الاين المتبعة دائما، ومن ثم وجب على المسلم الهجرة من المكان الأي يخاف فيه من إظهار دينه ويضطر فيه إلى التقية، ومن كمال الإيمان ألا يخاف في

(1) (1) سورة النحل الآية (7 (1) (1).

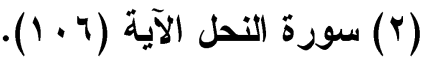

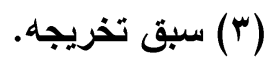


الله لومة لاهـــم كما قال تعـالى

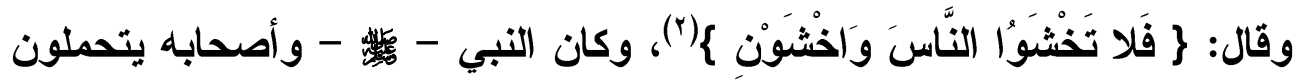
الأذى في سبيل دعوة الاين ويصبرون عليه.

ويدخل في التقية مداراة الكفرة والظلمة والفسقة وإلاحة الكلام لهم

والتبسم فى وجوههم وبذل المال لهم لكف أذاهم وصيانة العرض منهم، ولا يعد هذا من الموالاة المنهي عنها بل هو مشروع.

قال مجاهد: " والتقاة ليست بأن أكذب وأقول بلساني ما ليس في قلبي،

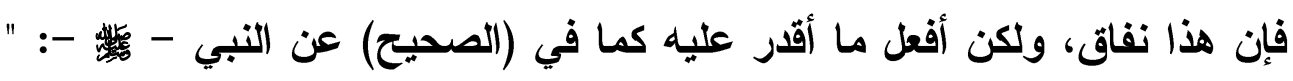
من رأى منكم منكرا " إلخ، فالمؤمن إذا كان بين الكفار والفجار لم يكن عليه أن يجاهدهم بيده مع عجزه، ولكن إن أمكنه بلسانه وإلا فبقلبه، مع أنه لا يكذب لئ ويقول بلسانه ما ليس في قلبه، إما أن يظهر دينه وإما أن يكتمه، وهو مع هذا لا يوافقهم على دينهم كله بل غايته أن يكون كمؤمن آل فرعون وامرأة فرعون، ونه وهو لم يكن موافقا لهم على جميع دينهم، ولا كان يكذب، ولا يقول بلسانه ما ليس في قلبه، بل كان يكتم إيمانه، وكتمان الدين شيء و إظهار الدين الباطل شيء

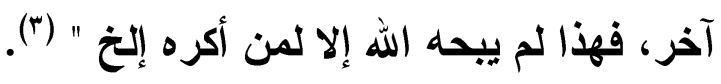

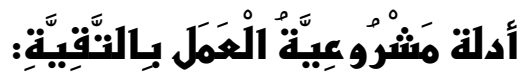

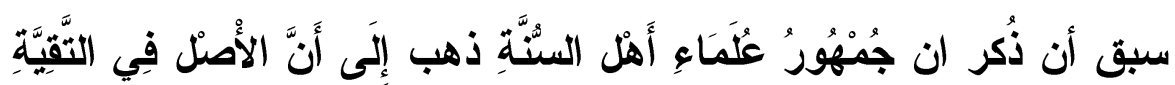

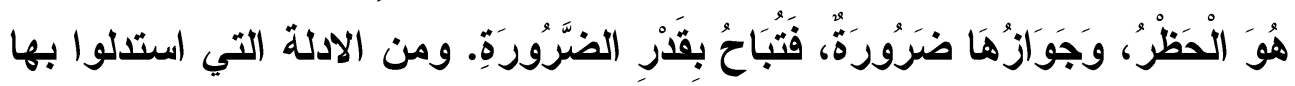
على مشروعيتها اضافة لما سبث من الآيات القر آنية والأحاديث النبوية:

(1) (1 سورة آل عمران من الآية (IV0).

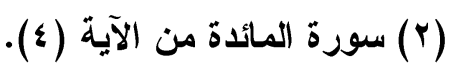

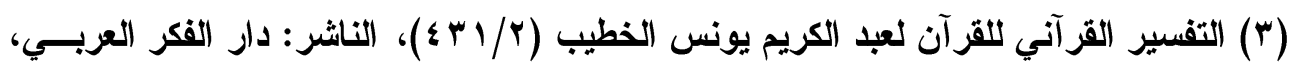
القاهرة.

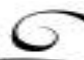




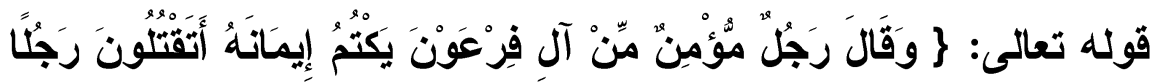

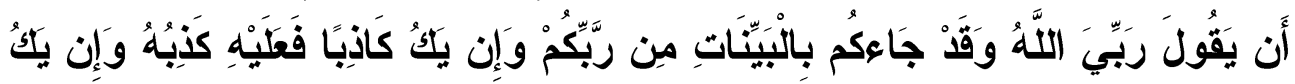

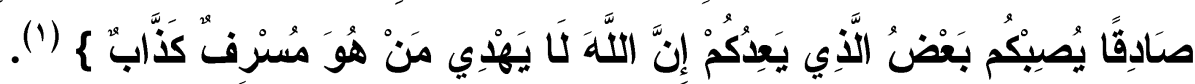

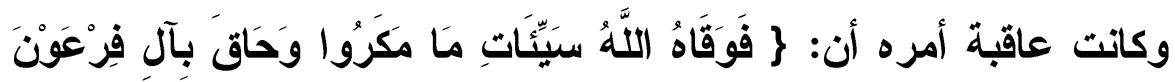

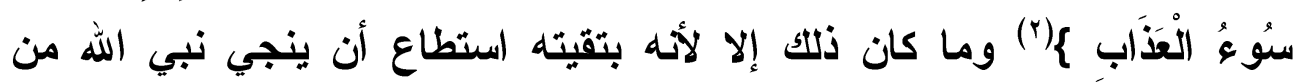

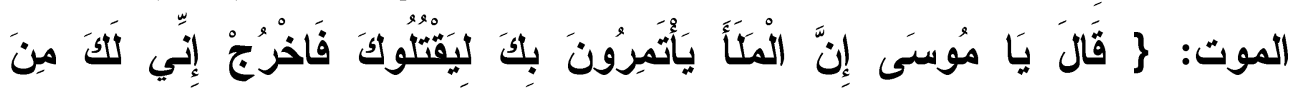
النَّاصِحِينَ $\left\{{ }^{(\top)}\right.$ وهذه الآيات تدل على جواز التقية لإقاذ المؤمن من شر عدوه الكافر واتقاء المسلم من المسلم في ظروف خاصة إن مورد الآيات وإن كان هو اتقاء

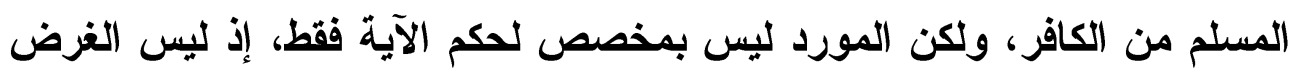
من تشريع التقية عند الابتلاء بالكفار إلا صيانة النفس والنفيس من الثر، فإذا ابتلي المسلم بأخيه المسلم الأي يخالفه في بعض الفروع ولا يتردد الطرف القوي

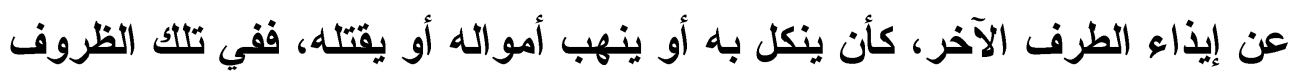
الحرجة يحكم العقل السليم بصيانة النفس والنفيس عن طريق كتمان العقيدة واستعمال التقية.

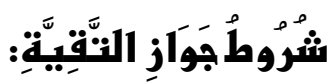
مذهب أهل السنة والجماعة ان التقية لا تجوز على الإطلاق كما سبق ذُكر ذلك ولكن لها شروط اشترطها العلماء للعمل بها من هذه الشروط:

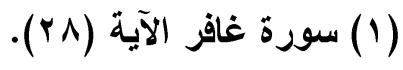

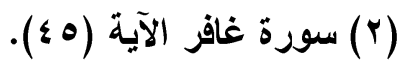

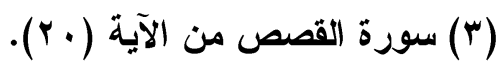




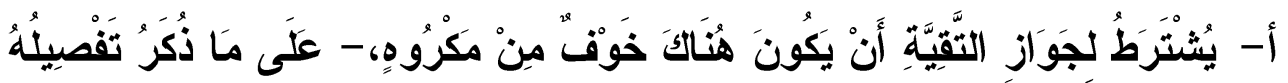

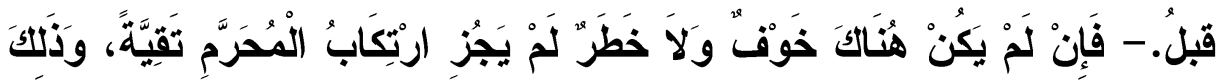

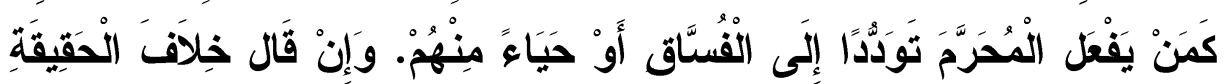

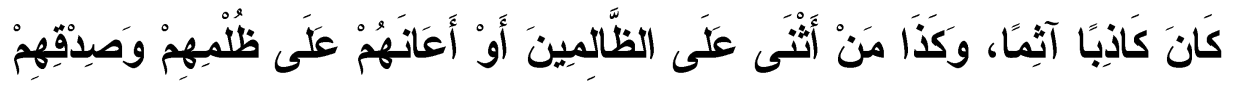

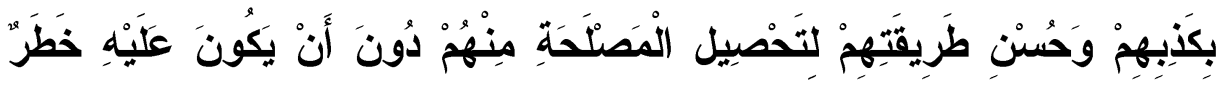

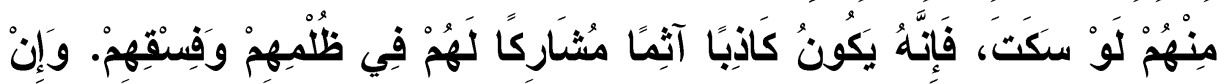

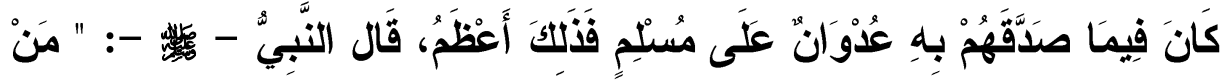

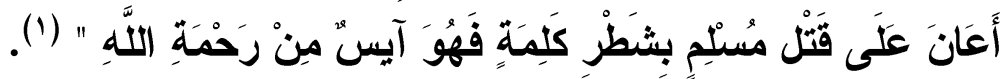

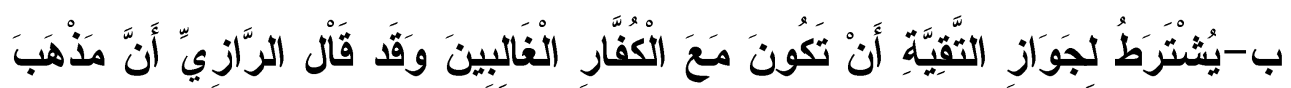

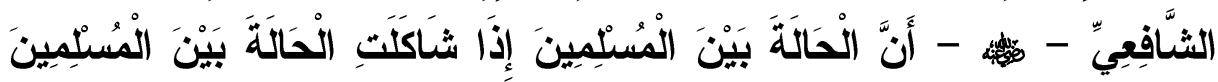

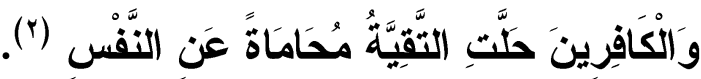

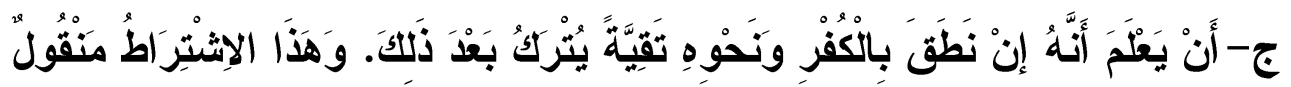

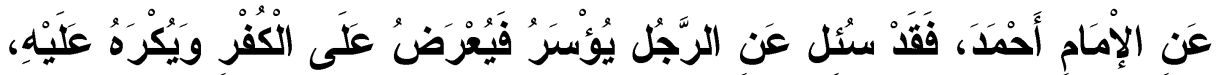

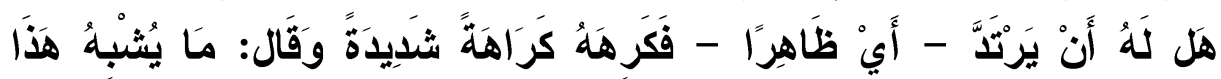

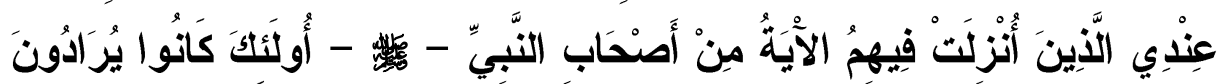

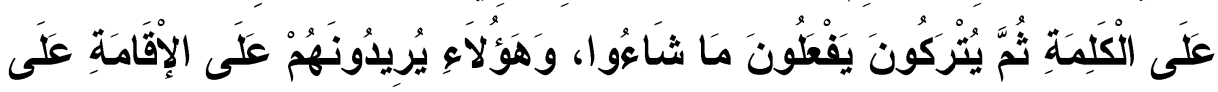

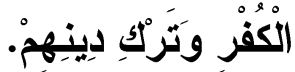

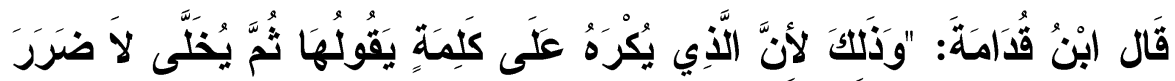

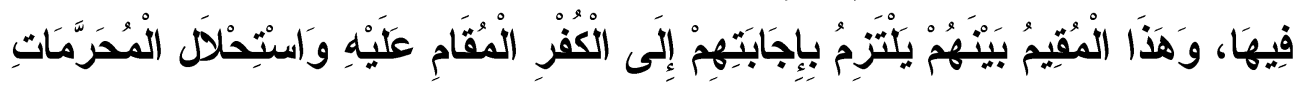

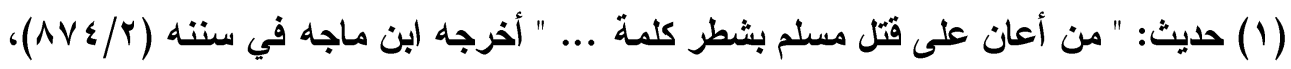

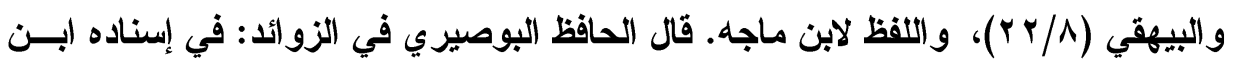

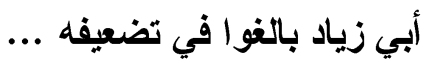

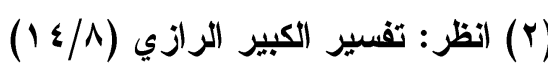




\section{د. قتحي محمود محمد عبد الرحمن}

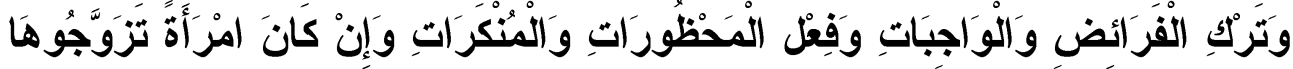

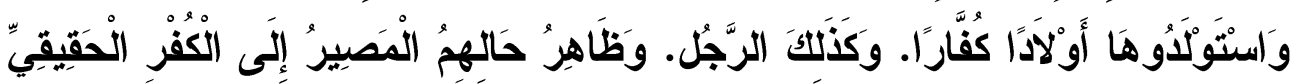

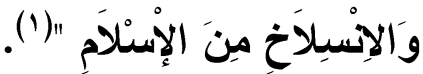

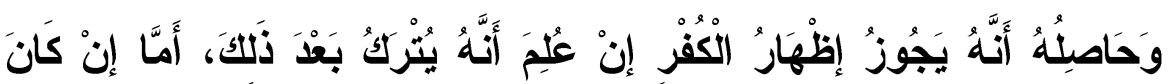

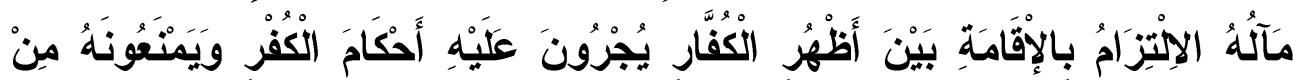

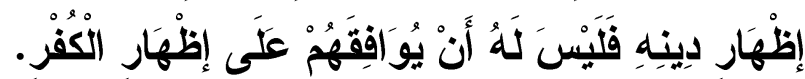

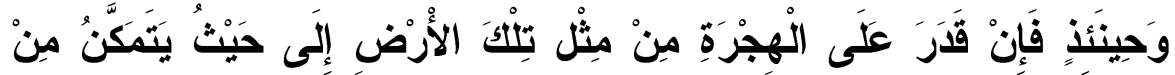

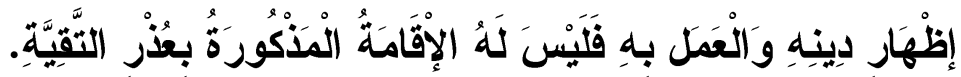

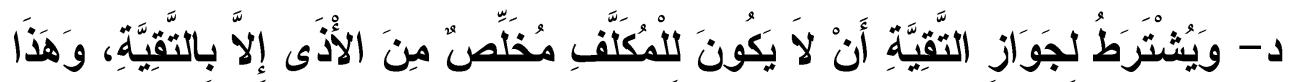

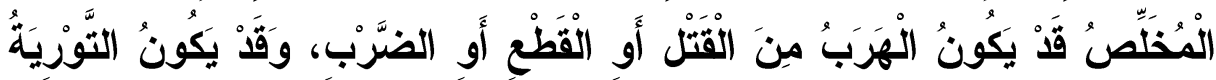

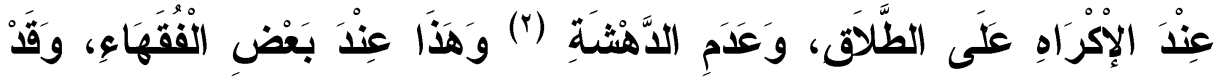

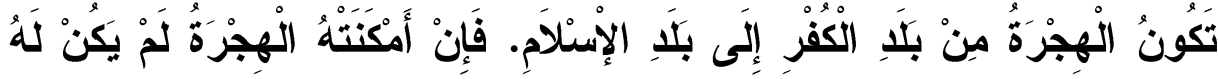

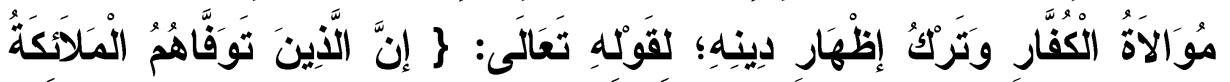

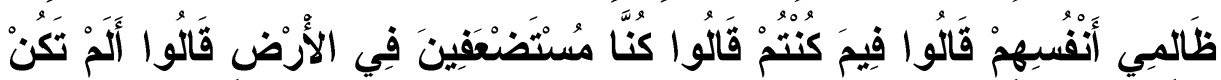

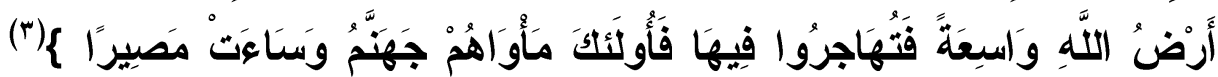

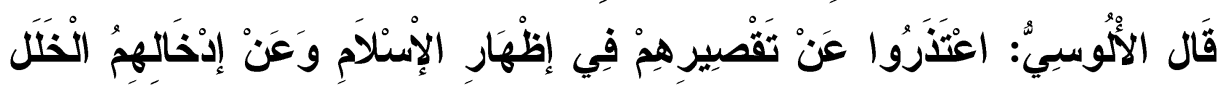

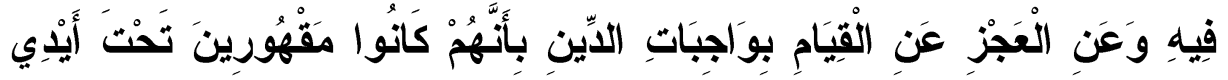

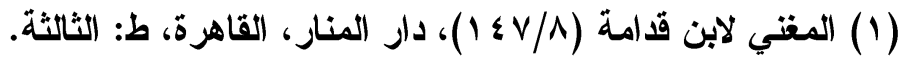

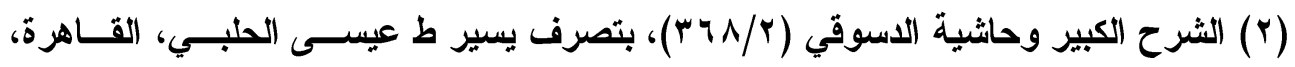




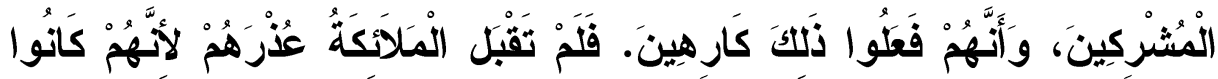

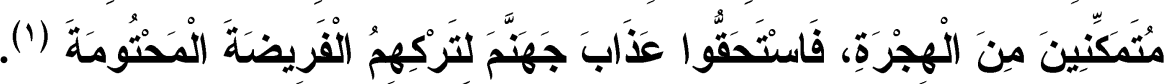

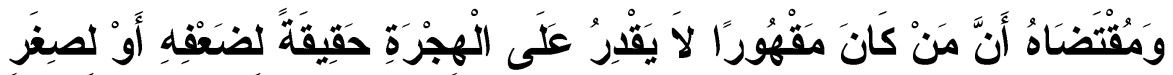

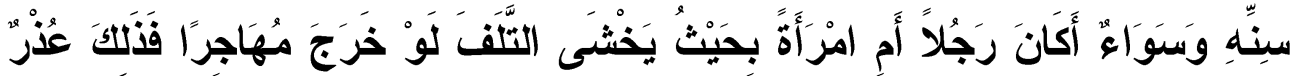

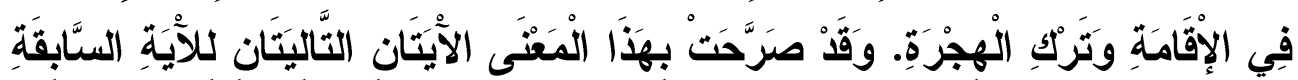

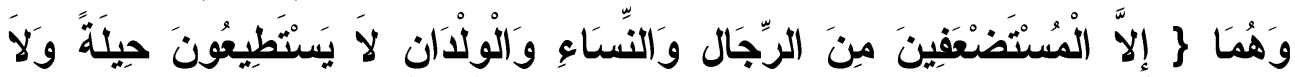

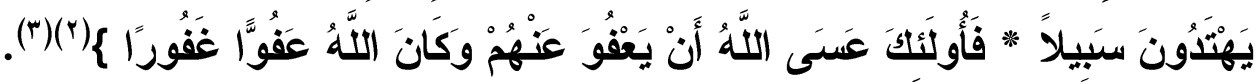

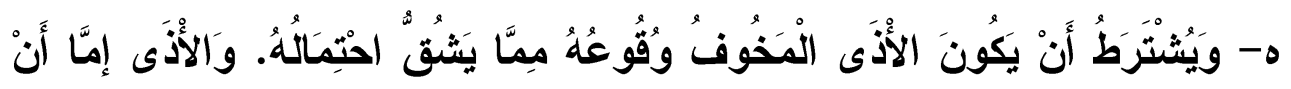

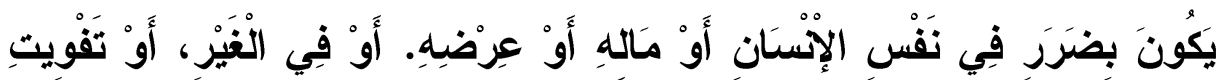

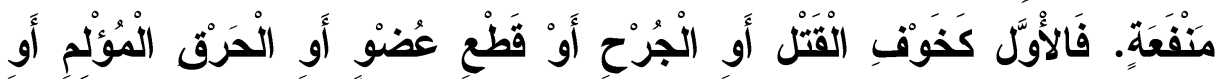

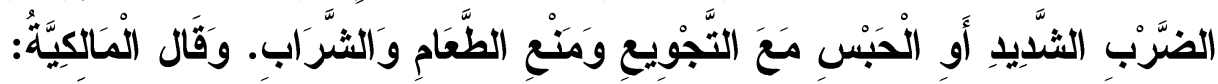

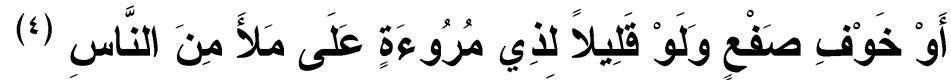

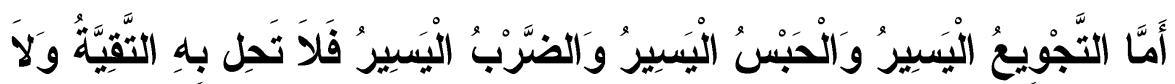

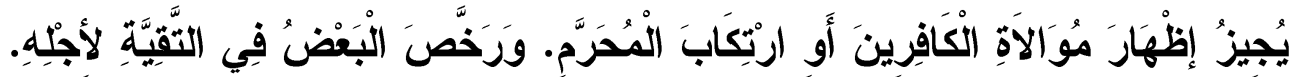

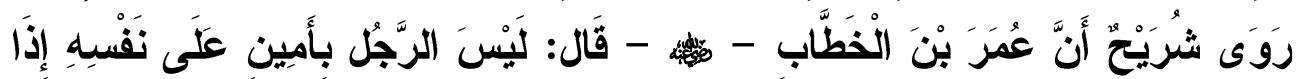

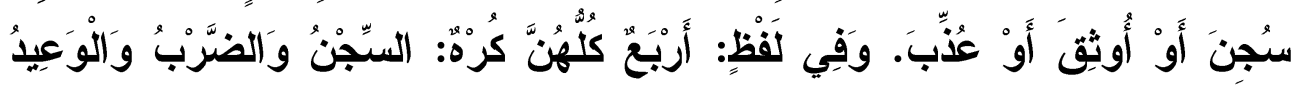

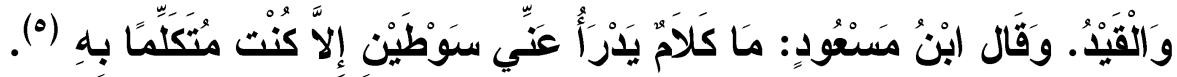

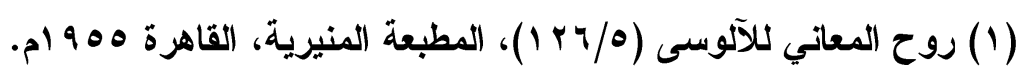

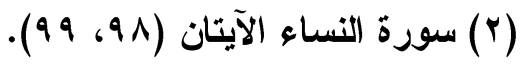

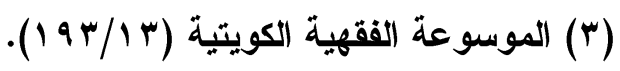

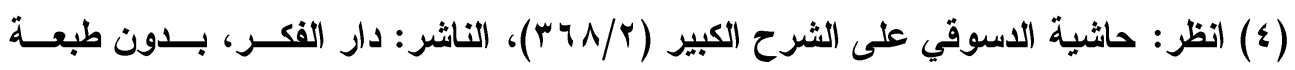
وبدون تاريخ.

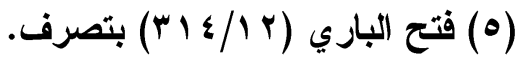




\section{د. قتحي محمود محمد عبد الرحمن}

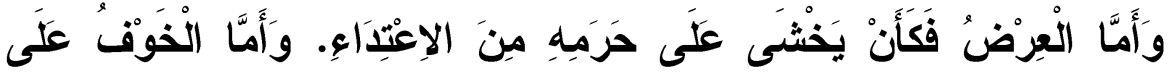

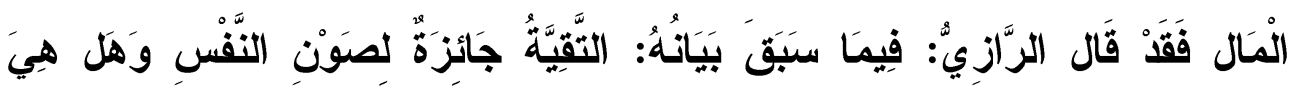

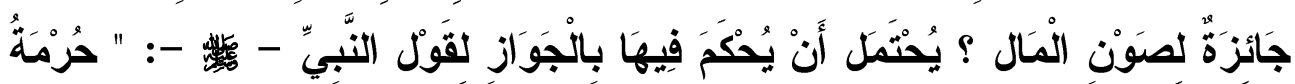

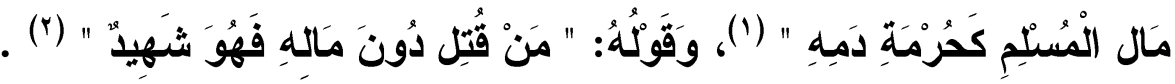

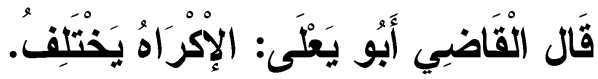

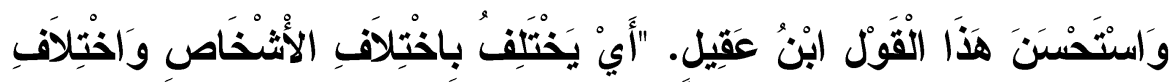

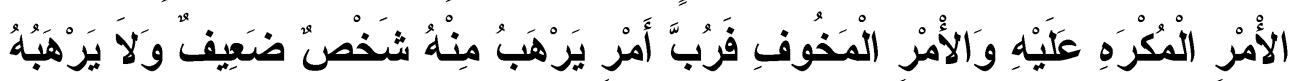

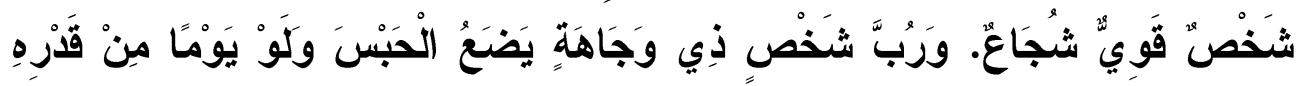

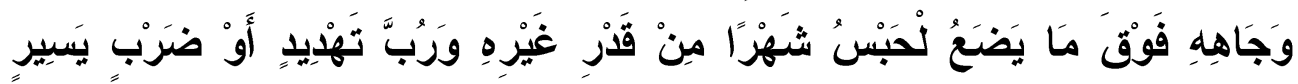

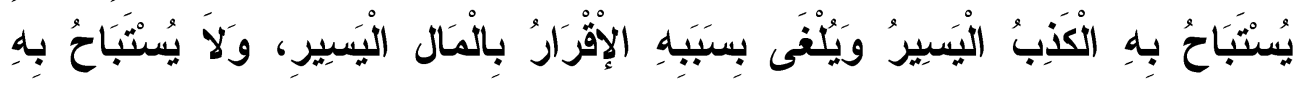

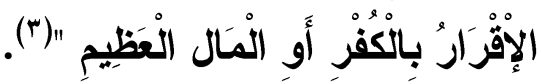

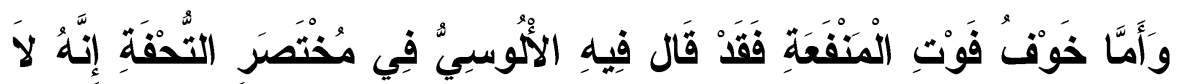

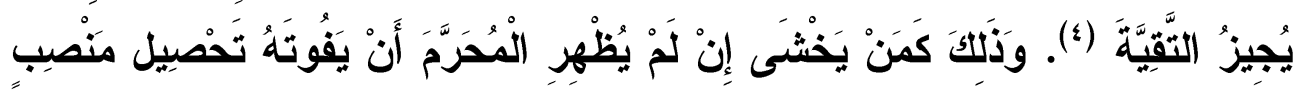

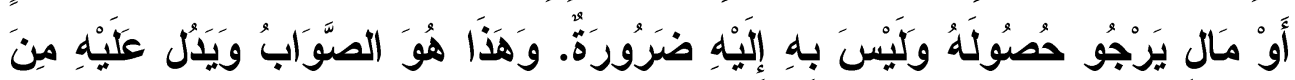

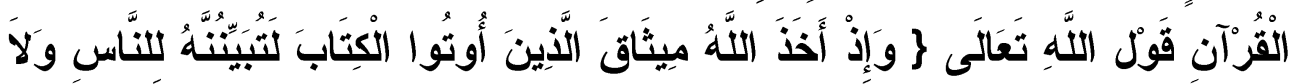

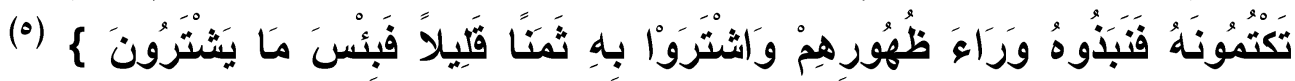

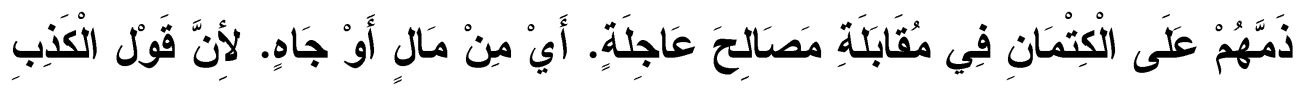

$$
\text { (Y) (Y) سبق تخريجه. }
$$

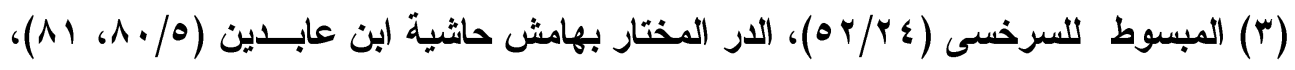

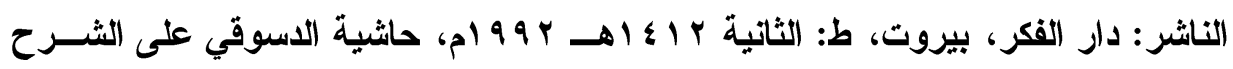

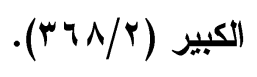

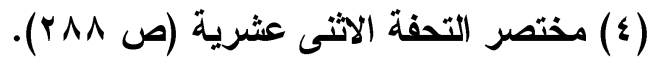

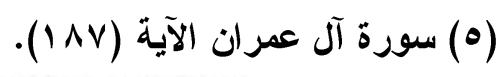




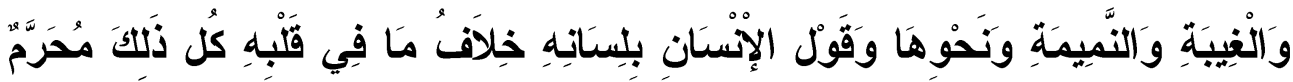

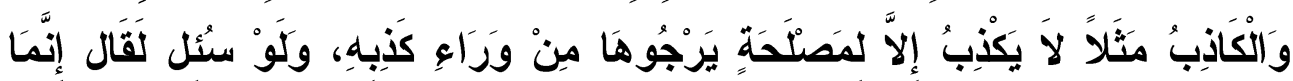

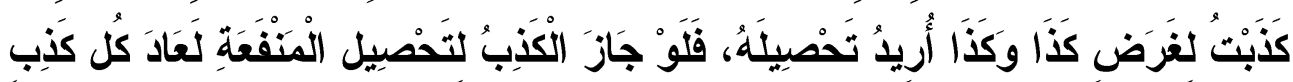

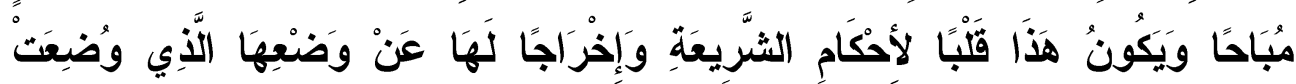
(1) مَنَيْهِ (1)

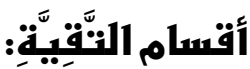

\section{هنايك أنواع وأقتسام للتقبة منهها:}

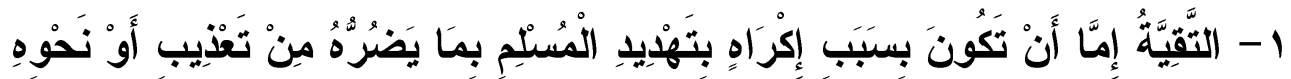

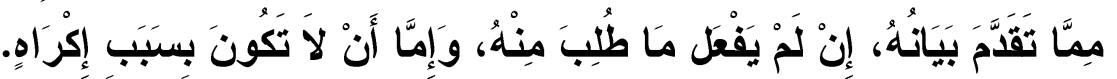

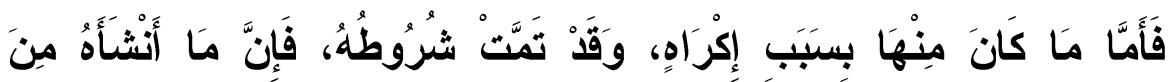

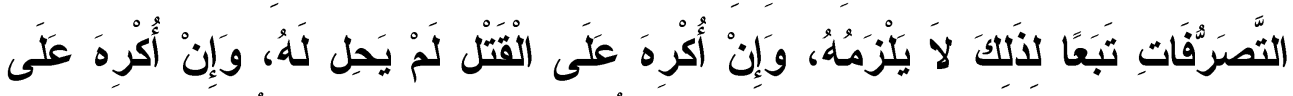

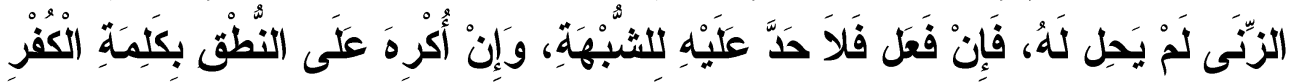

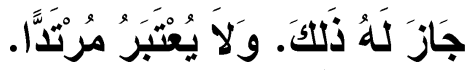

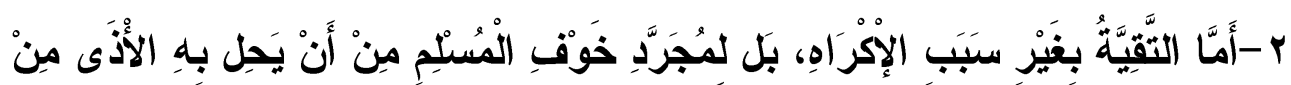

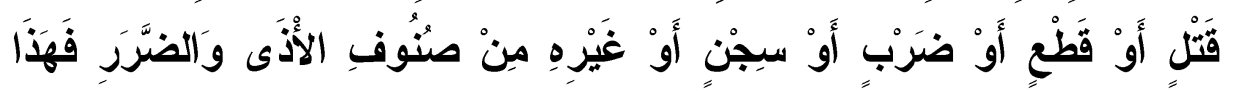

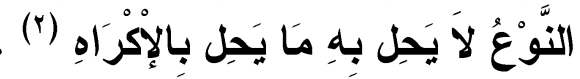

يقول الألوسي والعدو قسمان: الأول من كاتت عداوته مبنية على اختلاف

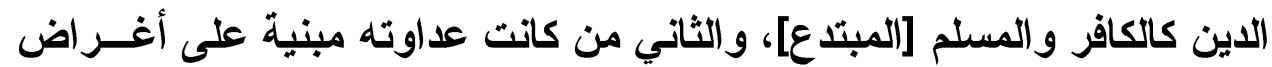
دنيوية كالمال و المتاع والملك والإمارة، ومن هنا صارت التقية قسمين: أما القسم

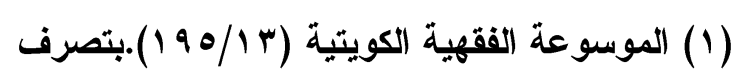

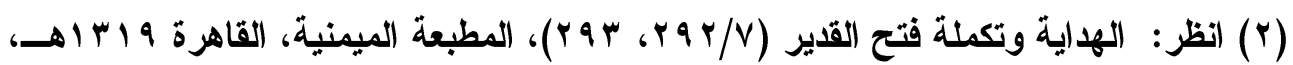

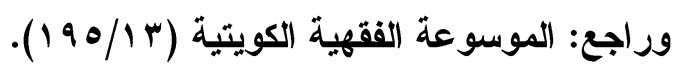


الأول: فالحكم الثرعي فيه أن كل مؤمن وقع في محل لا يمكن له أن يظهر دينه لتعرض المخالفين، وجب عليه الهجرة إلى محل يقدر فيه على إظهار دينــه، ولا

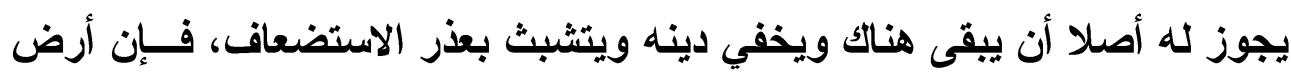

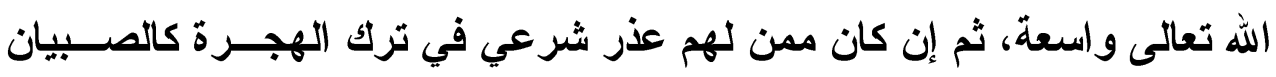
و النساء والعميان والمحبوسين والأين يخوفهم المخالفون بالقتل. أو قتل الأولاد.

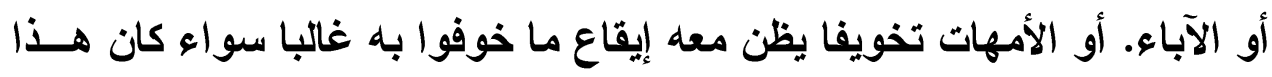

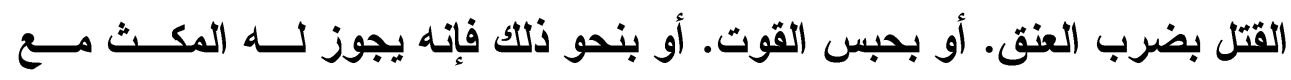

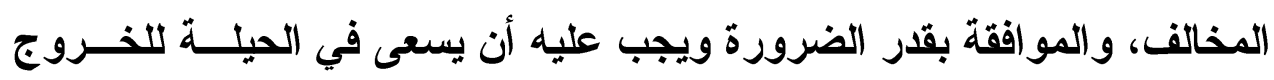
و الفرار بلينه. ولو كان التخويف بفوات المنفعة، أو بلحوق المشقة التي يمكنــه تحملها كالحبس مـع القوث، والضرب القليل غير المهلك لا يجوز لــه مـــوافقتهم، وفي صورة الجواز أيضا موافقتهم رخصة وإظهار مذهبه عزيمة فلو تلفت نفسه لألك فإنه شهيل

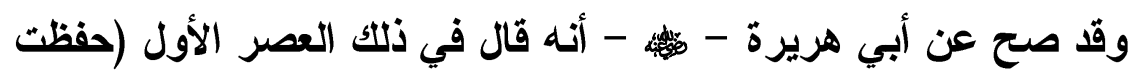

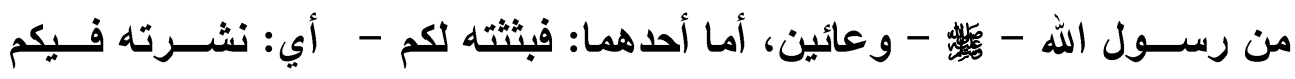

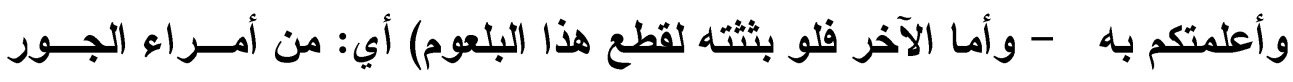
والظلم إذا جهر بهذا العلم.

ولذلك قال الغزالي في خطبة المقصد الأسنى: من جهل الحق جدير بـأن يتعامى، لكن من أبصر الحق عسير عليه أن يتعامى.

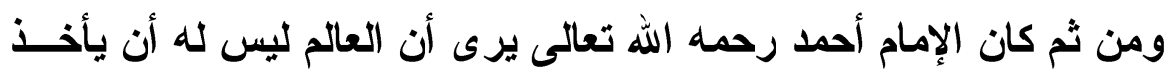
بالتقية؛ لأن العلماء العاملين الأين يعلمون الحق قلة، فإذا سكت العالم عن إظهار الحق الأي عنده مع جهل الناس؛ فمتى تقوم الحجة على هؤلاء الناس؟ والإمسام

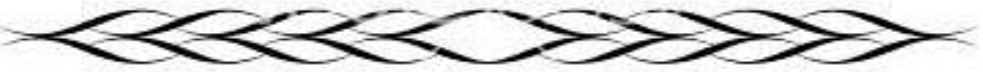




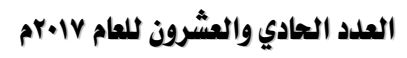
الجزء الأول المون

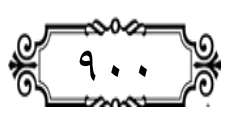

حولية كلية اللفة العربية بجرجا

مجلة علمية محكمة

أحمد أنكر أشد الإكار على من اتقى القول في فتنة خلق القرآن، وصمد هو وقلة

معه رحمه الله تعالى (')

مما سبث يتبين ان اهل السنة يرون أن التقية رخصة أباحها الله اذا توفرت فيها الثروط السالفة الأكر لمن أضر واحتاج إليها، والأين أجازوا

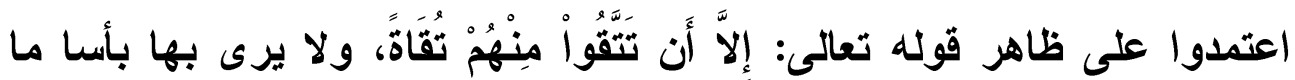
دامت الغلبة للكفار حيث لا ينجي صاحب التقية منهم إلا إظهار ولائه لهم ومو(فقته إياهم في الظاهر. وبعضهم قال: إن التقية لا تجوز، خصوصا بعد أن أن أعز الله الإسلام وانتشر بين الناس وصار المسلمون أهل قوة ومنعة، يقول

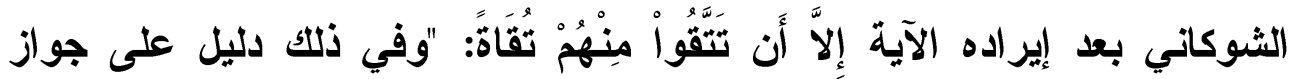
الموالاة لهم مع الخوف منهم، ولكنها تكون ظاهرا لا باطنا، وخالف في ذللك قوم

من السلف فقالوا: لا تقية بعد أن أعز الله الإسلام" (؟). والأين أجازوها من السلف يزون أنها لا تكون إلا باللسان فقط لا يتعدى

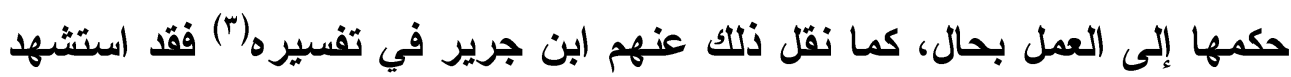
بأقوال عدد من العلماء كلهم لا يجيز في التقية إلا القول باللسان مع إضمار عداوة الكفار، وهكذا السيوطي - I -، فقد أورد عدة روايات في حكم التقية وأنها لا

تكون إلا باللسان فقط عندما تقتضي الضرورة ذلك (؛).

(1) انظر: تفسير القرآن الكريم: محمد أحمد إسماعيل المقدم (9 ب / آ، بترقيم الثاملة آليا).

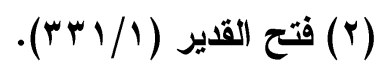

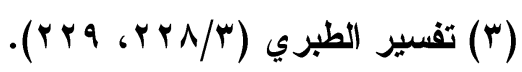

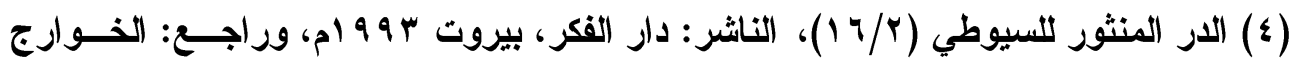
تاريخهم وآراؤهم الاعتقادية وموقف الإسلام منها لغالب عواجي (ص r به ؛ ). 
العذر بالنتقبة:

التقية حالة استثنائية لا تباح إلا لموجب، إذ الأصل في المسلم أن يتطابق ظاهره وباطنه، بحيث يكون ظاهره كباطنه، ولهذا كان التظاهر بكفر أو معصية من غير عذر نفاقاً وخداعاً لا يصح بحال في غير التقية إلا في حال واحدة هي أن يكون ذلك حيلة لمصلحة المسلمين في الحرب خاصة، دون غيرها لما صح عن

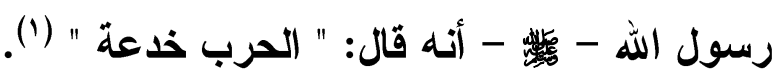

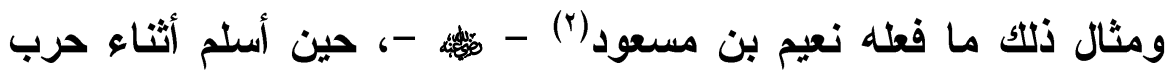
الأحزاب، ولم يكن أحد يعلم بإسلامه. فجاء إلى التبي - فئ - فقال: " يا رسول

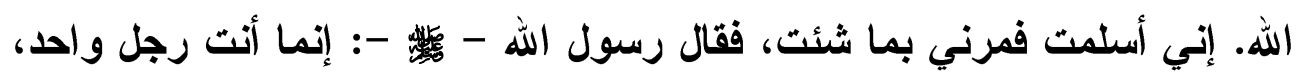

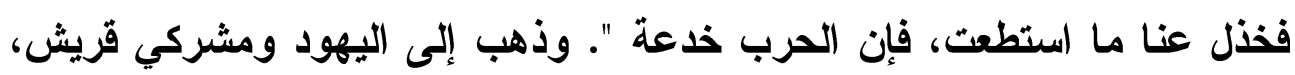
وأوهمهم بما فرق الله به بينهم، وكان مع ذلتك يتظاهر لكل منهم بالنصح، وأنه لم

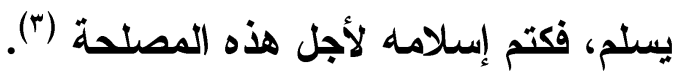

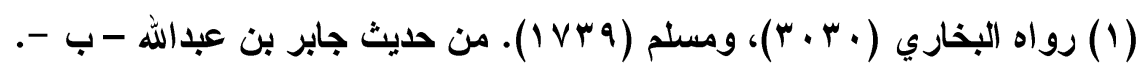

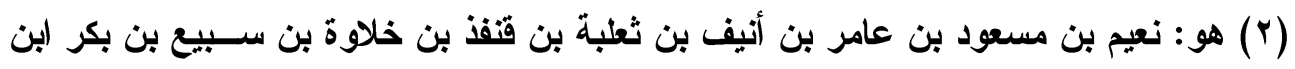

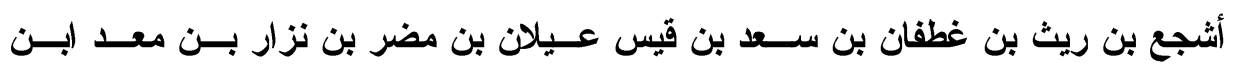

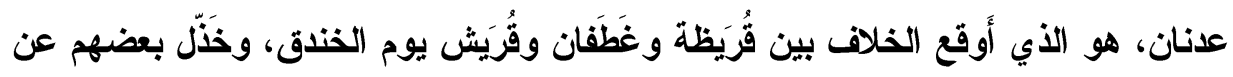

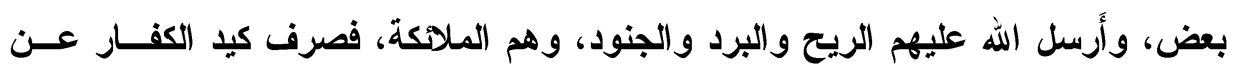

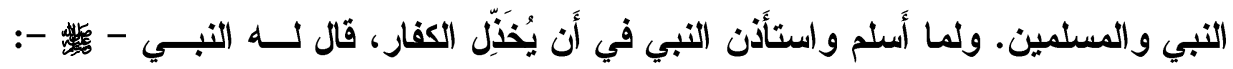

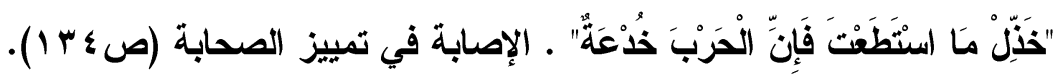

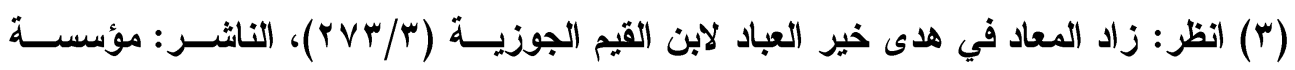

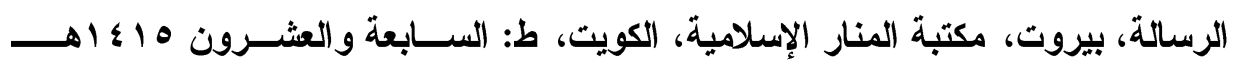

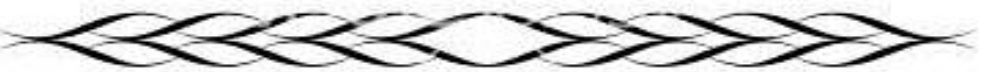


وأما الخدعة بإظهار الكفر فمثاله ما حصل من محمد بن مسلمة(1)

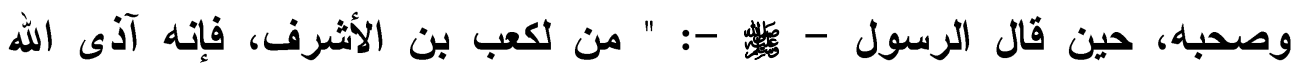
ورسوله ؟ فقام محمد بن مسلمة فقال: يا رسول الله أتحب أن أقتله ؟ قال: نعم.

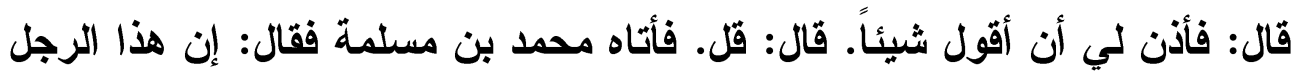
قد سألنا صدقة، وإنه قـ عنانا،، وإني قـ أتيتك أستسلفك. قال: وأيضاً والله لتملنه. قال: إنا قد اتبعناه فلا نحب أن ندعه حتى ننظر إلى أي شيء يصير شأنه

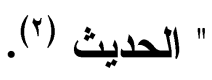

فهذا محمد بن مسلمة رضي الله عنه يستأذن الرسول - مأس - أن يقول

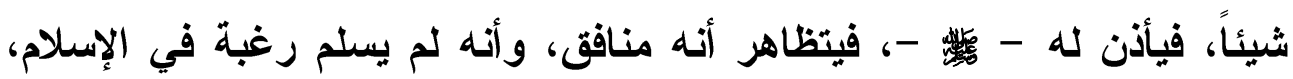
حتى يستدرج كعب بن الأشرف()، وكان ذلك حين خرج له في الليل فقتله محمد بن مسلمة وأصحابه.

وهذا مما يدخل في عموم الإعذار بمثل هذا في الحرب، ولهذا بوب الإمام البخاري رحمه الله لهذه القصة بقوله: (باب الكذب في الحرب). وبوب لهم الإمام أبي داود بقوله: (باب: العدو يؤتى على غرة ويتثبه بهم).

(1) أبو عبد الله محمد بن مسلمة الأصساري أحد الصحابة، ولد قبل البعثة بـاثنتين وعثـرين

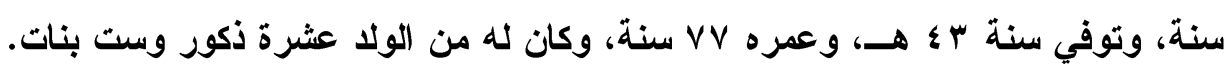

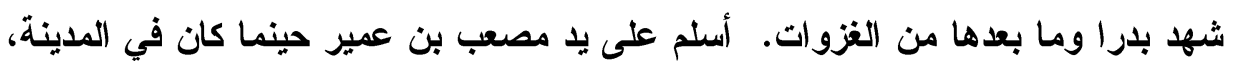

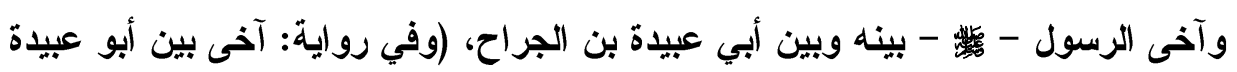

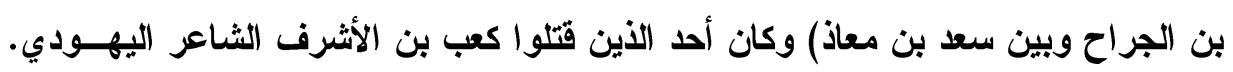

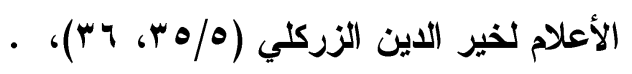

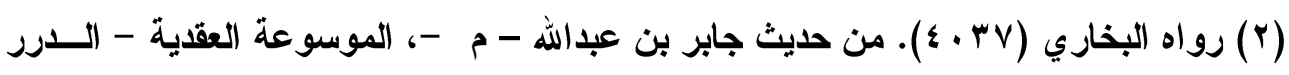

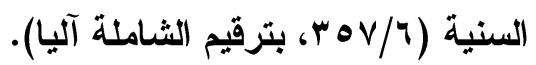

(r) كعب بن الأشرف: رجل من طيء وأمه من يهود بني النضير ذكر في سيرة النبي محمد 

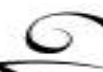


فمن هذا يتضح أن التقية إذا لم تكن لعذر تباح له، ولم تكن في حرب

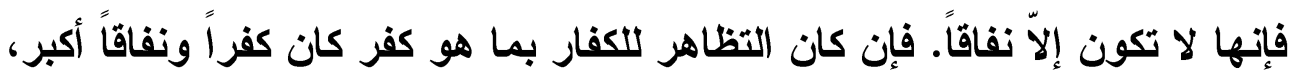
وإن كان بمعصية لم يكن ذلك من النفاق المخرج من الملة. بقي أن يعلم بعد ذلك الفرق بين التقية بكتمان الاين، والتقية بإظهار الكفر ، ومناط الإعذار في ذلك. أولاً: التقية بكتمان الدين:

الأصل في المسلم القيام بلينه وإظهاره وعدم الاختفاء به، وهذا واجب

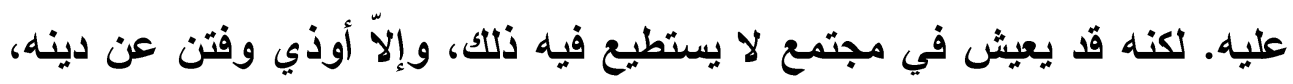
وهنا تجب عليه الهجرة إلى بلا يستطيع فيه إظهار دينه.

وهذا الوجوب هو مناط إيجاب الهجرة على من فتن في دينه ولم يستطع إظهاره. ولا علاقة لهذا بكون الادار كفر أو لا، فمتى تحقق الأمن للمسلم واستطاع إظهار دينه وموالاة المسلمين والبراعة من الكافرين لم تكن الهجرة واجبة عليه.

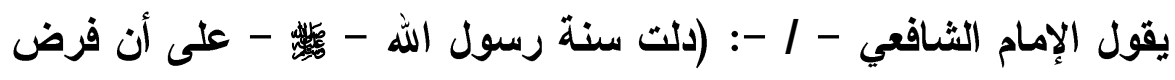
الهجرة على من أطاقها، إنما هو على من فتن عن دينه بالبلا الأي يسلم بها، لأن

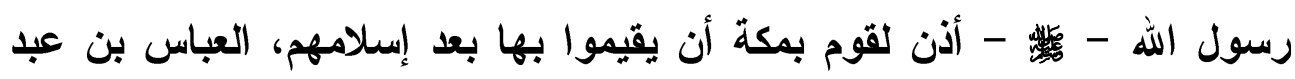

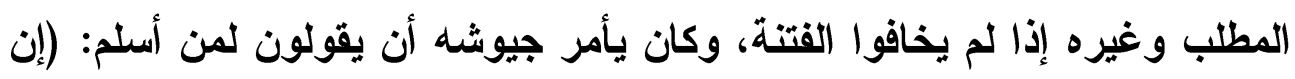

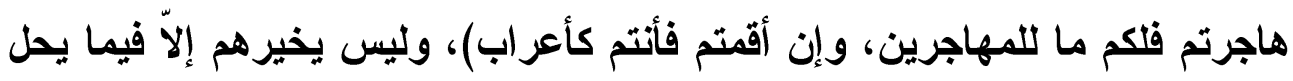

(1) (נים)

لكن ليس كل أحد يفتن في دينه يستطيع الهجرة فما الحكم ؟

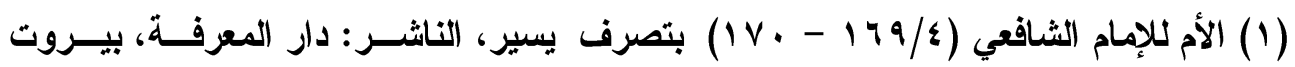

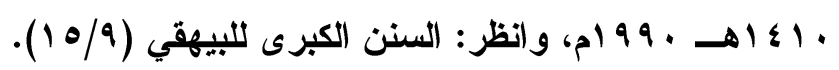




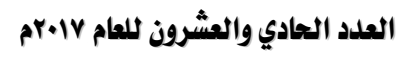

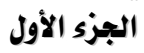

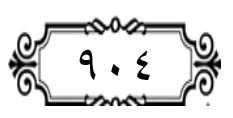

حولية كلية اللفة العربية بجرجا

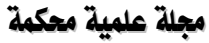

إن الواجب على المسلم أن يظهر دينه بقدر استطاعته، فإن خاف الفتنة ولم يستطع الهجرة جاز له كتمان دينه وعدم إظهاره لئلا يفتن. لكن مع الاستمساك به في الذفاء، وعدم مشايعة الكفار على كفرهم، بل ولا على معاصيهم ابتداءً من غير إكراه يبيح ذلك.

ومن هذا يعلم أن إنكار من كان حاله كذلك لا يمكن في الظاهر باليد ولا

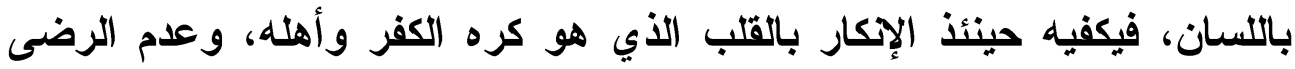

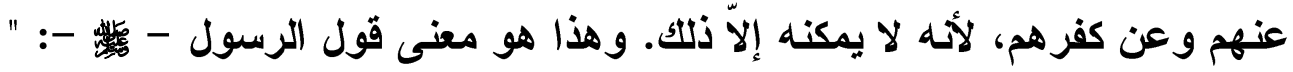

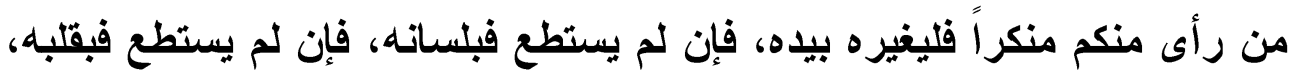

وذلكك أضعف الإيمان " (1).

وفي معنى قوله - مئد - في الحديث (فإن لم يستطع فبقلبه) يقول الإمام ابن دقيق العيد رحمه الله: "معناه فليكره بقلبه، وليس ذلك بإزالة وتغيير، لكنه هو

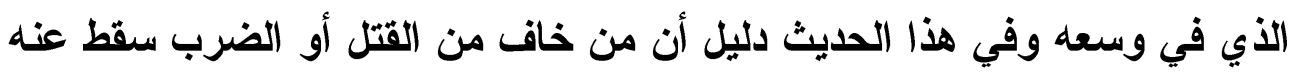
التغيير، وهو مذهب المحققين سلفاً وخلفاً، وذهبت طائفة من الغلاة إلى أنه لا لا

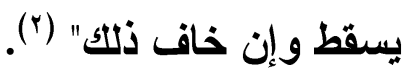

وأما من استطاع إنكار المنكر في الظاهر فلم يفعل فإنه يأثم لتركه الواجب

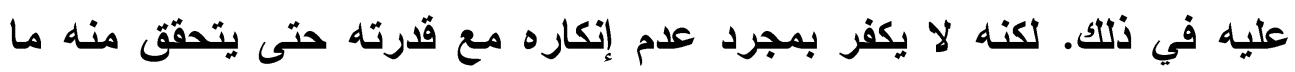
يستوجب الكفر في الظاهر من قول أو فعل. ... ولأجل ما تقدم، فإن الصحابة قد اختلفو ا في شأن من أسلم بمكة وبقي

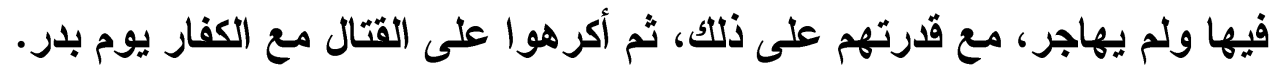

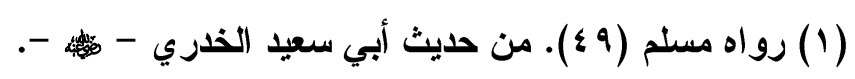

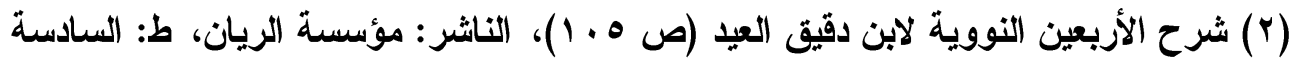

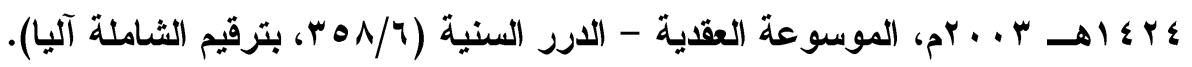


فمن الصحابة من تأسف لقتلهم، ومنهم من رأى أنهم يقتلون لأجل تفريطهم في عدم الهجرة، حتى أكرهوا على القتال مع المشركين. ولو كانوا عند هم كفاراً لم يتأسفو أعزم عليهم.

يقول الإمام محمد بن عبد الوهاب رحمه الله: "إن ناساً من المسلمين لم يهاجروا كراهة مفارقة الأهل والوطن والأقارب فلما خرجت قريش إلى بدر خرجوا معهم كرهاً، فقتل بعضهم بالرمي، فلما علم الصحابة أن فلاناً قتل وفلاناً

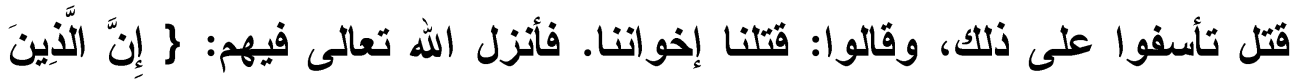

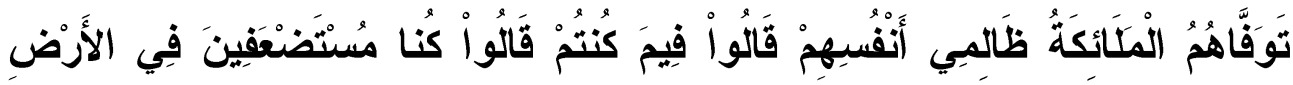
(1)

فليتأمل الناصح لنفسه هذه القصة، وما أنزل الله فيها من الآيات، فإن أولئك لو تكلموا الكفر، وفعلوا كفراً ظاهراً يرضون به قومهم لم يتأسف الصحابة على قتلهم، لأن الله بين لهم وهم بمكة لما عذبوا قوله تعالى: \} مَن كَفَرَ بِاللهِ من

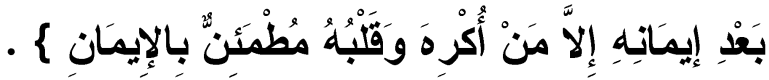
فلو كانوا سمعوا عنهم كلاماً أو فعلا يرضون به المشركين من غير إكراه

ما كانو ا يقولون: قتلنا إخوانتا" (r). ثانيًا: التقية بإظهار الكفر:

لا يجوز بحال إظهار الكفر ابتداء من غير إكراه بلعوى التقية، بل لا

يجوز ذلك بما هو معصية.

(1) سورة النساء الآيات (1) - (1) - (1).

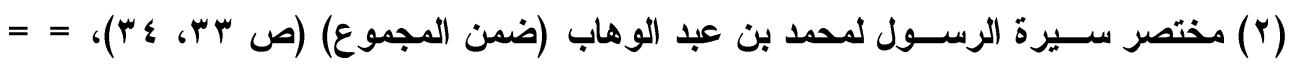

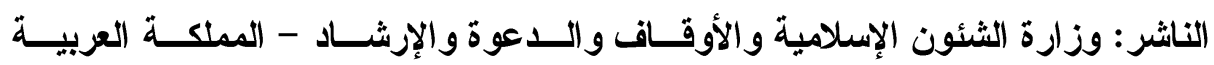

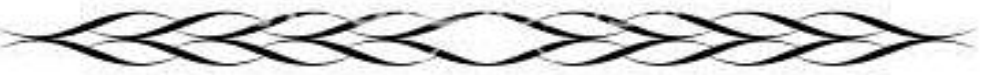


ولهذا لما فعل حاطب بن أبى بلتعة(1) - هوله - ما فعل، من مكاتبة كفار

قريش بخبر مسير الرسول - مئس - والمسلمين معه لفتح مكة لم يعذره الرسول -

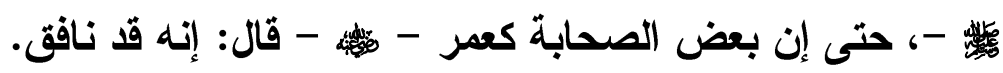

لكن الرسول - كئس - تبين حاله، لاحتمال أن يكون فعله كفراً وردة عن الإسلام، أو أن يكون معصية لا تخرجه من الملة.

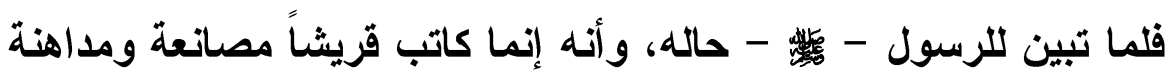
لهم، وتقية لأجل حفظ ماله وأهله بمكة، لا مظاهرة للمشركين ولا موالاة لهم على لهـ دينهم لم يكفره، وكاتت تلك المعصية منه مغفورة بحسنته العظمى يوم بلر. فإذا كان هذا في معصية ولم يعذر حاطب - هولئه -، بل كان آثماً بذلك فكيف بالكفر ؟ فالتظاهر بكفر أو معصية من دون عذر يبيح ذلتك يوجب المؤاخذة بحسب ما تحقق في الظاهر من كفر أو معصية، وهذا الاشتراط في التقية هو حقيقة الفرق بين منهج أهل السنة في التقية ومنهج الثيعة في ذلك فإن التقية عندهم

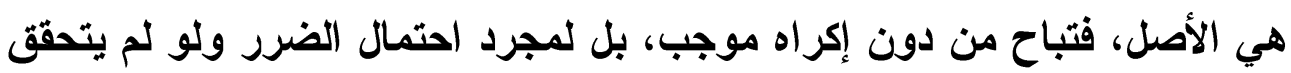

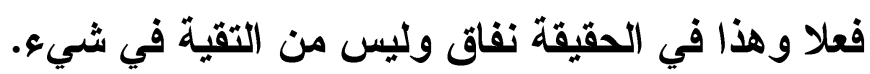
يقول شيخ الإسلام ابن تيمية في بيان هذه المسألة: " التقاة ليست بأن أكذب وأقول بلساني ما ليس في قلبي، فإن هذا نفاق، ولكن أفعل ما أقدر عليه كما

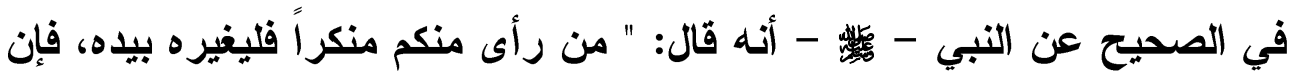
لم يستطع فبلسانه، فإن لم يستطع فبقلبه، وذلك أضعف الإيمان " (r).

(1) حاطب بن أبي بلتعة اللخمي، صحابي بلري، أسلم وهاجر إلى يثرب، وشارك ميع النبـي -

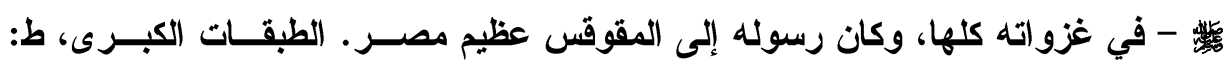
العلمية .

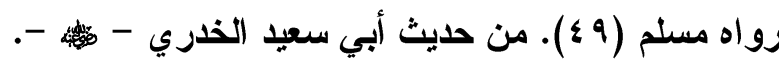

\section{0}


فالمؤمن إذا كان بين الكفار والفجار لم يكن عليه أن يجاهدهم بيده مع عجزه، لكن إن أمكنه بلسانه وإلا فبقلبه. مع أنه لا يكذب ويقول بلسانه ما ليس في قلبه، إما أن يظهر دينه وإما أن يكتمه، وهو مع هذا لا يوافقهم على دينهم كله، بل غايته أن يكون كمؤمن آل فرعون وامرأة فرعون. وهو لم يكن مواققا لهم على جميع دينهم، ولا كان يكنب ولا يقول بلسانه ما ليس في قلبه، بل كان يكتم إيمانه، وكتمان الدين شيء وإظهار الدين الباطل شيء آخر، فهذا لم يبحه الله إلا لمن أكره، بحيث أبيح له النطق بكلمة الكفر، والله تعالى قـ فرق بين المنافق والمكره. والرافضة حالهم من جنس حال المنافقين، لا من جنس حال المكره الأي أكره على الكفر وقلبه مطمئن بالإيمان " ( '). ومن هنا نعلم الفرق بين المناط في الإعذار بكتمان الاين، وأنه العجز عن إظهاره ولو لم يكن إكراه. وأما إظهار الكفر والمعصية فلابد لإباحة التقية فيه الإكراه. وذلك لأن القيام بتحقيق المطلوب مشروط بالاستطاعة، وأما ترك المنهي فالأصل فيه الترك، وليس مما تشترط فيه الاستطاعة، وإنما يكون اشتراط الاستطاعة عند الإكراه على المخالفة بفعل المنهي عنه. ولهذا قال الرسول أمرتكم بأمر فأتوا منه ما استطعتم " (^) فعم الأمر بالامتناع عن كل منهي عنه، وقيد فعل المأمور بالاستطاعة. وعلى هذا الأصل أعني اشتراط الإكراه في التظاهر بالكفر - أدلة كثيرة،

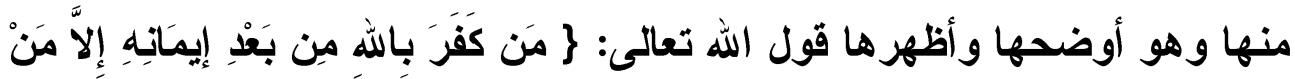

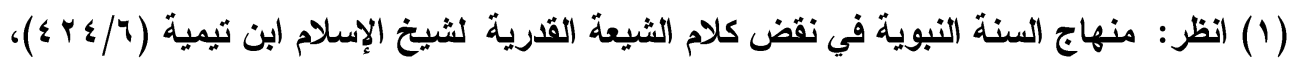

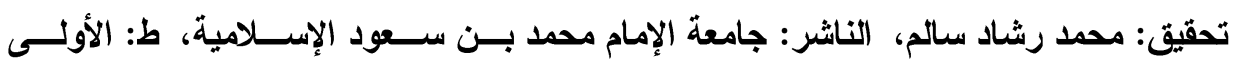

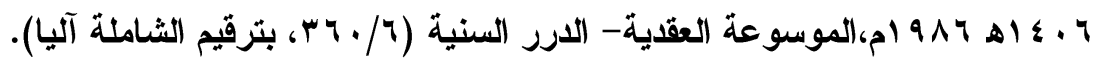

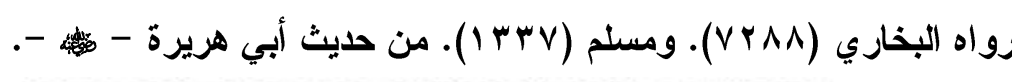




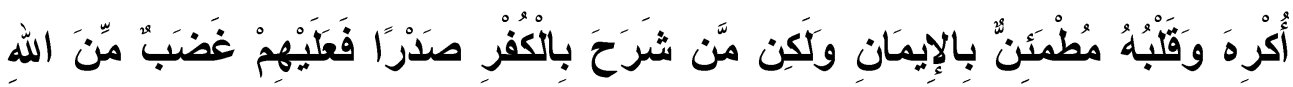

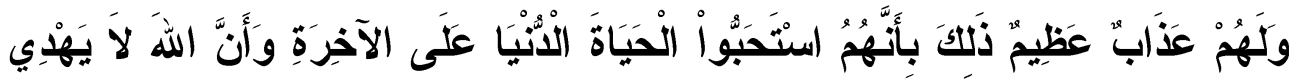

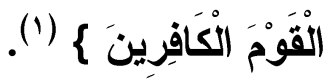

فلم يعذر الله أحداً في الكفر الظاهر بغير الإكراه. فمن تظاهر بالكفر ولم يكن مكرها فإنه لا يكون إلا كافراً، لاششراح صدره بالكفر، لتلازم الظاهر والباطن. فلا عذر لأحد في ذلك بغير الإكراه مطلقا، سواء كان كفره محبة لوطنه أو لأهله وعشيرته أو توقعه أذى الكفار ونحو ذلك.

يقول الشيخ الإمام محمد بن عبد الوهاب - / - في بيان دلالة هذه الآية

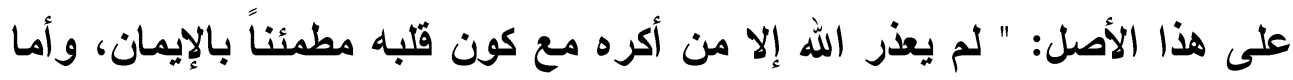
غير هذا فقد كفر بعد إيمانه، سواء فعله خوفاً أو مداراة أو مشحة بوطنه أونه أو أهله أو عشيرته أو ماله، أو فعله على وجه المزح أو لغير ذلك من الأغراض إلا ملأ المكره. فالآية تل على هذا من وجهين:

الأول: إِلاَّ مَنْ أُكْرَهَ فَلم يستثن الله تعالَى إلا المكره، ومعلوم أن الإنسان لا يكره إلا على الكلام أو الفعل، وأما عقيدة القلب فلا يكره عليها أحد.

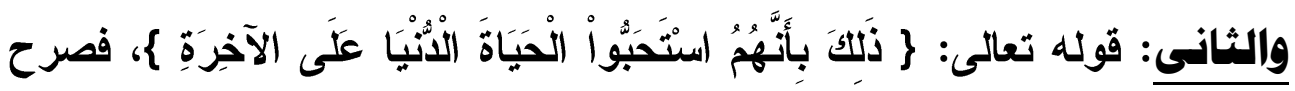
أن هذا الكفر والعذاب لم يكن بسبب الاعتقاد أو جهل أو البغض للاين أو محبة الكفر، وإنما سببه أن له في ذلك حظاً من حظوظ الدنيا فآثره

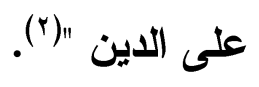

(1) سورة النحل الآيتان (7 - 1، V • (1).

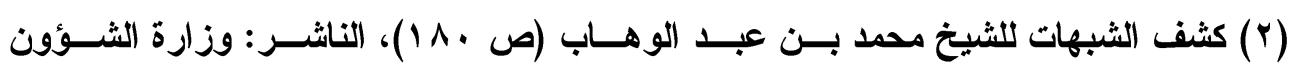

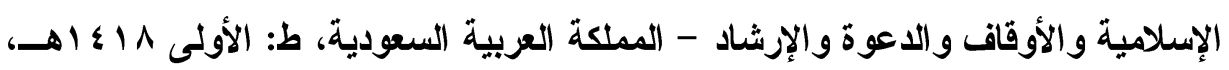
الموسوعة العقدية - الارر السنية (؟/ آبس، بترقيم الثاملة آليا). 


\section{د. قتحي محمود محمد عبد الرحمن}

ولهذا فإنه لما كان بمكة قوم قد نطقوا بالشهادتين، لكنهم ظاهروا المشركين من غير إكراه، لـ يعذرهم الله تعالى، بل حكم بنفاقهم وكفرهم، وبين

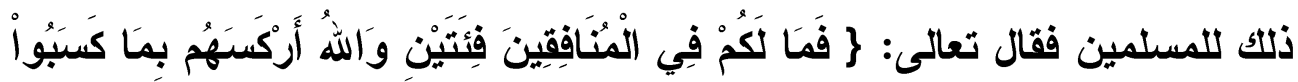

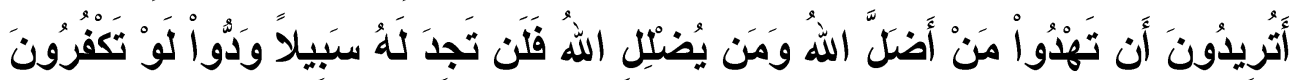

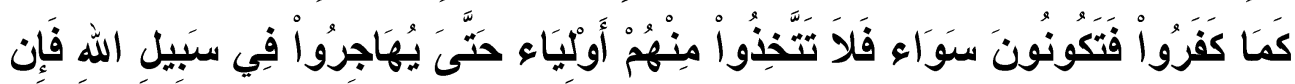

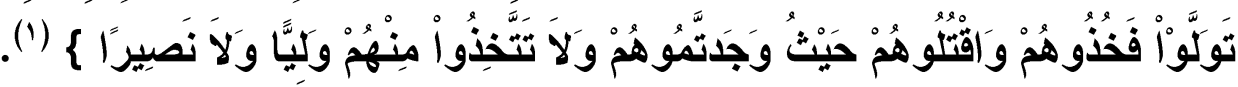
يقول الإمام ابن كثير - I -: " قال العوفي عن ابن عباس نزلت في قوم كانوا بمكة قد تكلموا بالإسلام وكانوا يظاهرون المشركين، فخرجوا من مكة الإمن يطلبون حاجة لهم، فقالوا: إن لقينا أصحاب محمد فليس علينا منهم بأس. وإن المؤمنين لما أخبروا أنهم قـ خرجوا من مكة قالت طائفة: اركبوا إلى الجبناء فاقتلوهم، فإنهم يظاهرون عليكم عدوكم. وقالت فئة أخرى من المؤمنين: سبحان الله أو كما قالوا، أتقتلون قوما قد تكلموا بمثل ما تكلمتم به من أجل أنهم لم

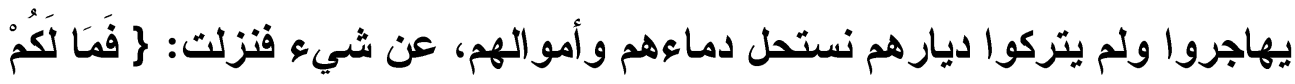

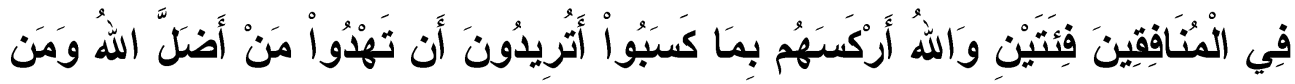

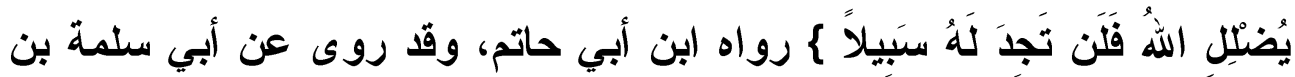
عبدالرحمن وعكرمة ومجاهد والضحاك وغيرهم قريب من هذا) (r). فهؤلاء لما ظاهروا المشركين ووالوهم على دينهم لم ينفعهم ما تظاهروا به من الإسلام لأن ما فعلوه لم يكن تقية أكرهوا عليها، وإنما كان اختيارا منهم لذلتك، فلم يكن لهم عذر، وعلى هذا الأصل تفهم آية التقية، وهي قول الله تعالى:

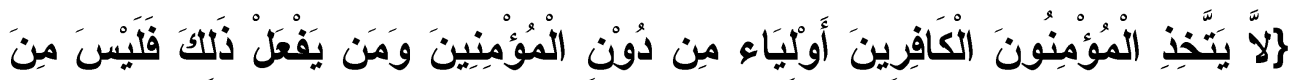

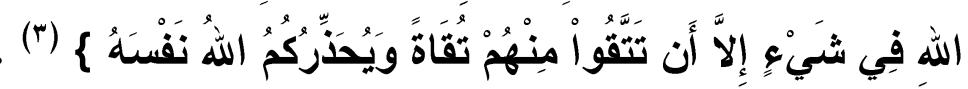

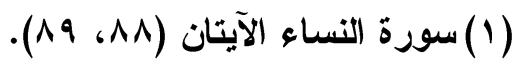

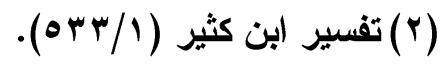

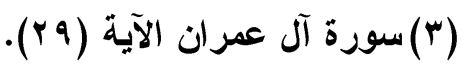


فمعنى الآية هو: أن مظاهرة المشركين وموالاتهم على دينهم كفر مطلقا، سواء كان ذلك بقول أو فعل إلا أن يكون ذلك تقية. والتقية في ذلك لا تكون بمجرد الخوف وتوقع الضرر، وإنما تكون بحصول الإكر اه حقيقة.

فهنا فرق بين التقية بكتمان الاين، والأي يكفي في الإعذار فيه مجرد

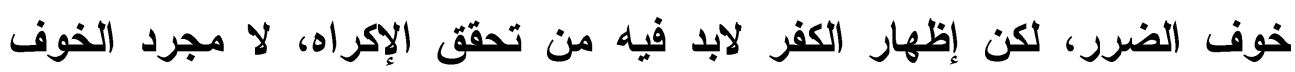
والتوقع.

ومما يدل على أن موالاة الكافرين خوفاً منهم أو مشحة بالوطن كفر ما لم

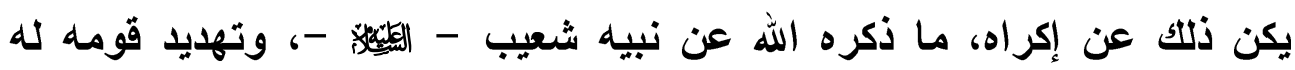
بإخر اجه من أرضهم إن لم يعد في ملتهم، ويو(فقهم على ما هم عليه. ولكن نبي الله شعيبا عليه السلام قال كما حكى الله عنه: \} قَهِ افْتَرَيَنَا عَلَى

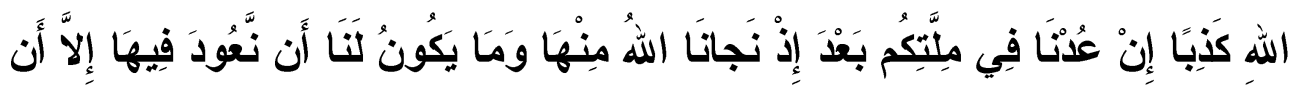

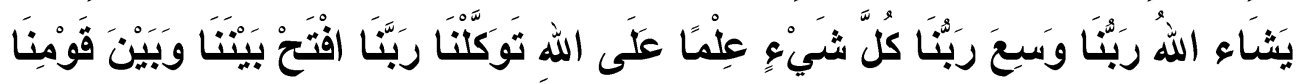

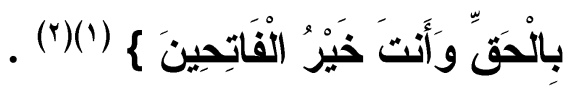
المكهة من مشرو عية النققية:

ان التقية لم تشرع عبثا ولكن هنالك حكمة في تشريعها ولنتظر إلى حكمة التثريع في هذا الأمر. إن كل مبدأ من مبادئ الخير جاء ليواجه ظاهرة من

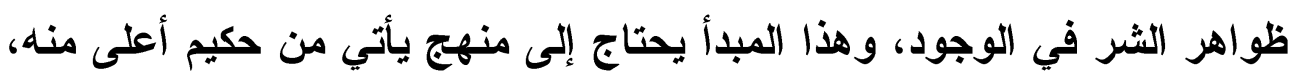

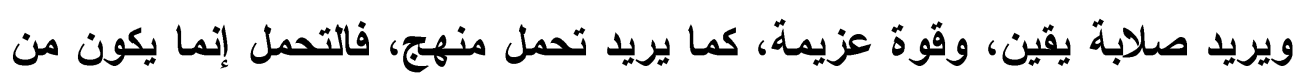

$$
\text { (1) سورة الأعر اف الآية (19). }
$$

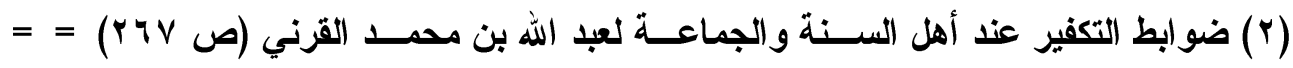
بتصرف، المصدر: موقع مكتبة صيد الفوائد. 


\section{د. قتحي محمود محمد عبد الرحمن}

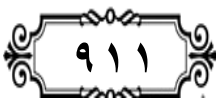

التقية

مند الخوارج وموقف أهل السنة منها

أجل أن يبقى المنهج للناس، والعزيمة من أجل أن يواجه المؤمن الخصوم، فلو لم

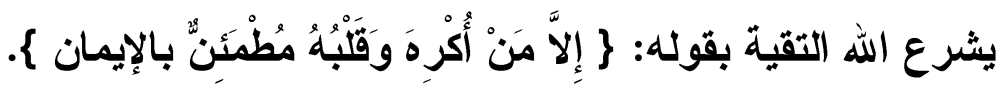

لكنا حقيقة سنحقق الفدائية التي تفدي مناهج الحق بالتضحية بالحياة رخيصة في سبيل الله، ولكن هب ان كل مؤمن وقف هذا الموقف فمن يحمل علم الله إلى الآخرين؟ لألك يشرع الحق سبحانه وتعالى التقية من أجل أن يبقى من يحمل المنهج، إنه يقرر لنا الفداء للعقيدة، ويشرع لنا التقية من أجل بقاء العقيدة. لقد جاء الحق بالأمرين: أمر الوقوف في وجه الباطل بالاستشهاد في سبيل الحق، وأمر التقية حماية لبعض الخلق حتى لا يضيع المنهج الحق لو جاء جبار، واستأصل المؤمنين جميعا، لذلك يشرع الحق ما يبقى للفداء قوما، ويبقى للبقاء

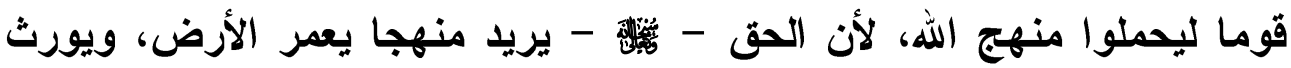

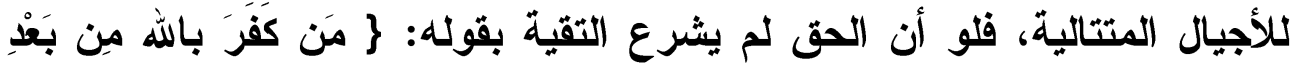

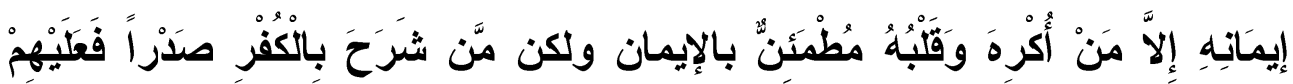

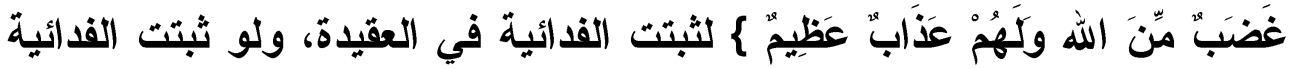
وحدها لكان أمر المنهج عرضه لأن يزول، ولا يرثه قوم آخرون، لألك شرع الله التقية ليظل أناس حول شمعة الإيمان، يحتفظون بضوئها؛ لعل واحدا يأخذ بقبسها، فيضيء بها نورا وهاجا. ولذلك، فلا ولاية من مؤمن لقوم كافرين إلا أن

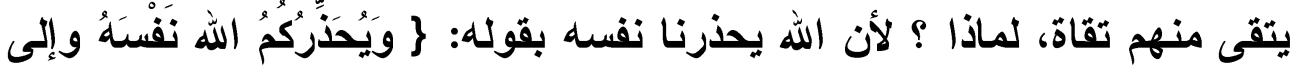

الله المصير \{ (1)

يقول الثيخ الشعراوي فإياك أن تقبل على السلوك الأي يضعه أمامك الكفار بانشراح صدر وتقول: أنا أقوم بالتقية، بل لا بد أن تكون المسألة واضحة في نفسك، وأن تعرف لماذا فعلت التقية، هل فعلتها لتبقى منهج الخير في الوجود، أو لغير ذلك ؟ هل فعلتها حتى لا تجعل جنود الخير كلهم إلى فناء أو غير

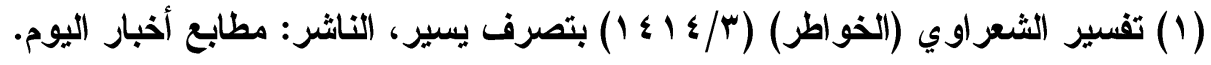


ذلك؟ إنك إن فعلت التقية بوعي واستبقيت نفسك لمهمة استبقاء المنهج الإيماني،

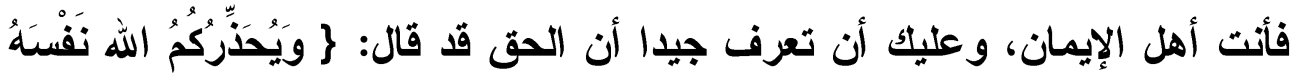
و إلى الله المصير \{. إنه الحق يقول للمؤمنين: إياكم أن تخلعوا على التقية أمرا هو مرغوب لنفوسكم، لماذا ؟ لأن الحق قد حددها: \} مَن كَفَرَ بالله مِن بَعْدِ إيمَانِهِ

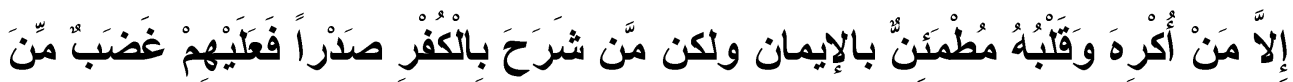

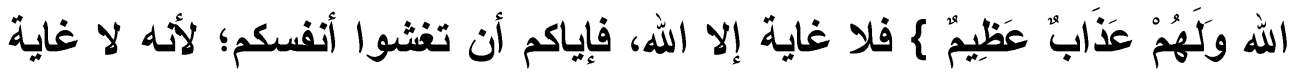

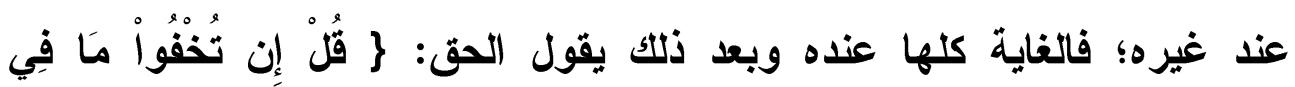

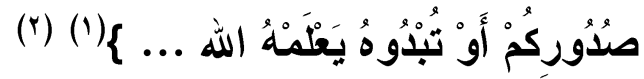
ولهذا فهنائ أمور يحسبها الناس من التقية وليست منها من هذه الأمور:

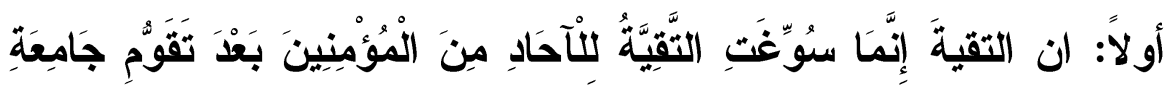

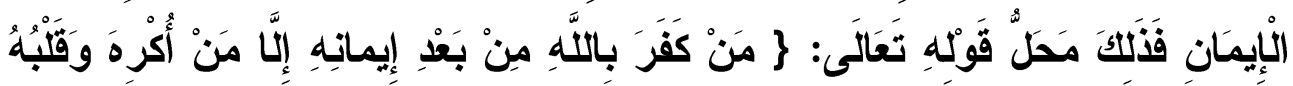

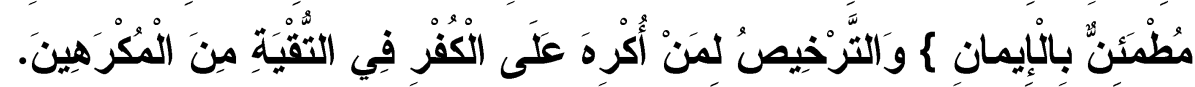
وإن التقية الأحادية أمر لَا يعلمه إلا الله، وقد يمالئ بقلبه ولسانه رجاءَ

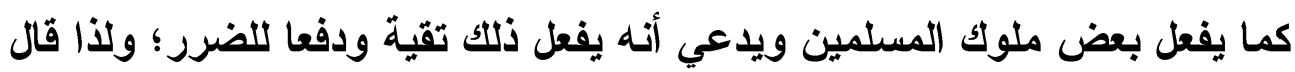

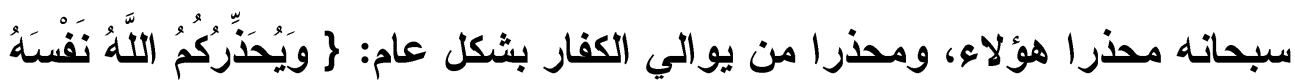

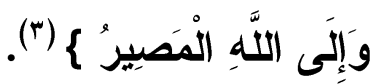

ثانيا: ليس من التقية المرخص فيها أن تقوم المودة بين المؤمن وبين الكافر - والكافر هو الذي لا يرضى بتحكيم كتاب الله في الحياة على الإطلاق، كما

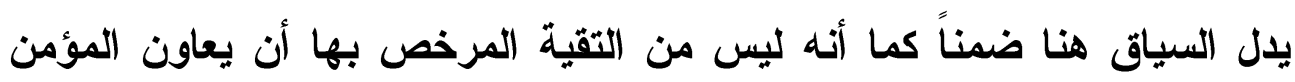

$$
\begin{aligned}
& \text { (1) سورة آل عمران من الآية (ج) (ب). }
\end{aligned}
$$

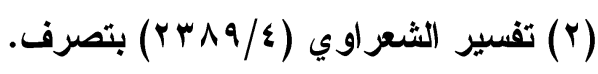

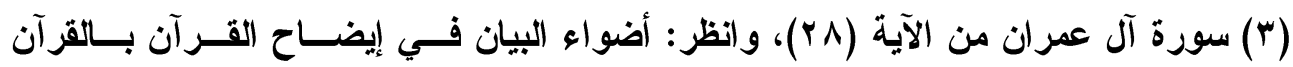

$$
\cdot(r / \wedge / r)
$$


الكافر بالعمل في صورة من الصور باسم التقية. فما يجوز هذا الخداع على الله! ولما كان الأمر في هذه الحالة متروكاً للضمائر ولتقوى القلوب وخثيتها من علام الغيوب، فقد تضمن التهديد تحذير المؤمنين من نقمة الله وغضبه في صورة

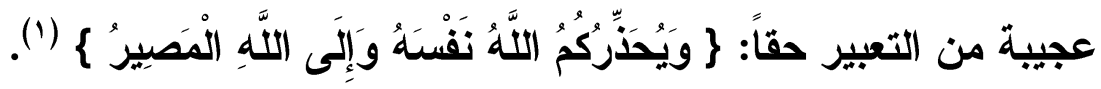




\section{الخاتمهة}

الحمد لله الأى تتم بنعمته الصالحات، وتحقيق الطيب من الأمنيات، فنسأله سبحانه أن يجعل آخر أعمالنا خواتيمها، وأن يجعل آخر أعمارنا أواخرها.

فهذه خاتمة لاراستنا حول موضوع: التقية عند الخوارج وموقف اهل السنة من ذلك، وقد أسفرت هذه الار اسة عن النتائج الآتية:

1. أنَّ التقيَّة مِن الأحكام الثرعية الثابتة في كتاب الله - تعالى - وفي سنَّةّة

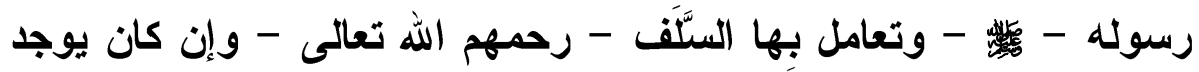
وجه شبه بين الخوارج وأهل السنة في ذلك فهو تشابه في اللفظ لان هنائ فرق بين التقية التي قال بها الخوارج وأهل السنة.

r. أن التقية عند أهل السنة والجماعة لا تكون إلا للضرورة عند تحقق الخوف من الكفار وغيرهم، وأنها مع هذا رخصة تركها أفضل، وبشرط أن لا يرجع ضررها إلى غير صاحبها وأنها باللسان لا بالقبل.

r. التقية من فروع الدّيّن، وليست هي من أصول الدِّين بحيث يكْفر تاركُها، أو يَخرج من الملَّة.

ع. الثقية الثرعية إنَّما يَلْجأ إليها في حالة الضَّفف لا في جَيع الأحوال ولا يجوز أن تكون سجيَّة للمسلم في جميع أحواله.

\section{0}




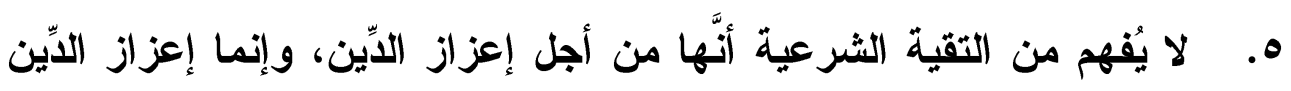
يكون من خلال إظهاره على الملأ، وعدم كتمانه، كما قال الله تعالى:

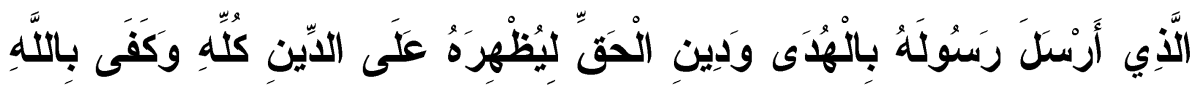
شَنَهِيدًا $\{$ (')

وفى الختام نسأل الله أن يجعل هذا العمل خالصا لوجهة الكريم وأن ينفع به كل طالب حقيقة وعلم سديد، وصل الله على سيدنا محمد وعلى آله وصحبه وسلم. 


\section{فهرس المسادر والمراجع}

$$
\text { ا ـ الابراضية آن الكريم (جل من أنزله). }
$$

r. إباضية في ميزان أهل السنة لعبد الله بن مسعود السني.

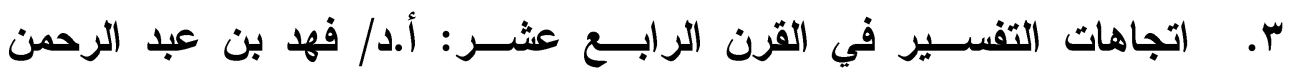
ابن سليمان الرومي، الناشر: طبع بإذن رئاسة إدارات البحوث العلمية والافتاء والدعوة والارشاد في المملكة العربية السعودية، ط: الأولى - مो917 أه

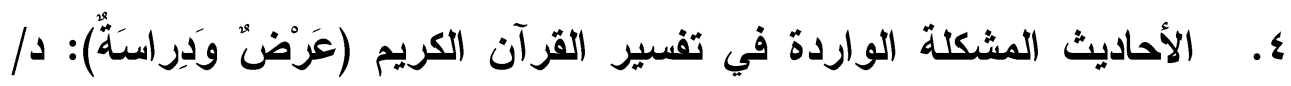

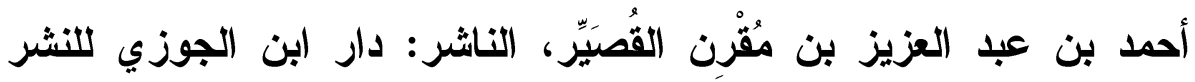

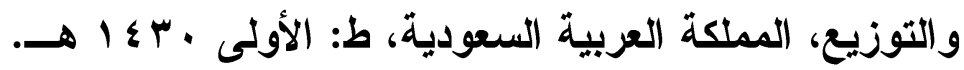

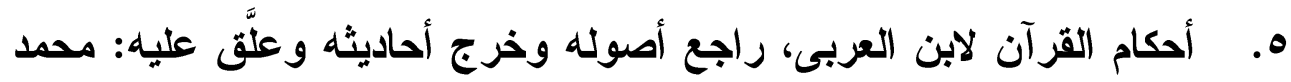
عبد القادر عطا، الناشر: دار الكتب العلمية، بيروت، لبنان، ط: الثالثة،

$$
\text { • }
$$

7. أحكام القرآن للجصاص، تحقيق: عبد السلام محمد علي شاهين، الناشر:

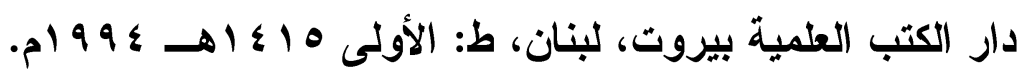

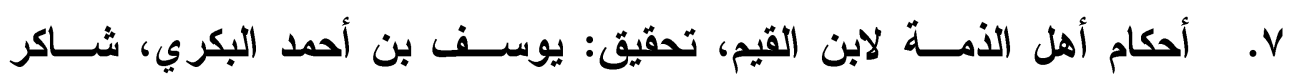

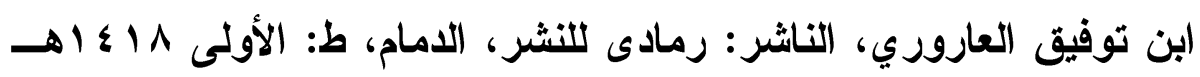
. $199 \mathrm{~V}$ ^. إحياء علوم الاين لأبى حامــد محمد بن محمد الغزالي، الناشر: دار

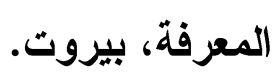
9 . إشاد الساري لشرح صحيح البخاري للقسطلاني، الناشر: المطبعة الكبرى

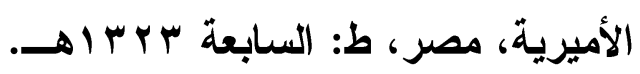

\section{0}




\section{د. قتحي محمود محمد عبد الرحمز}

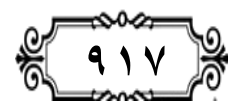

التقية

عند الخوارج وموقف أهل السنة منها

• 1 . الأسساس في التفسير لسعيد حوّى، الناشر: دار السلام، القاهرة، ط: السادسة .

1ا. أسد الغابة في معرفة الصحابة لابن الأثير، تحقيق: علي محمد معوض،

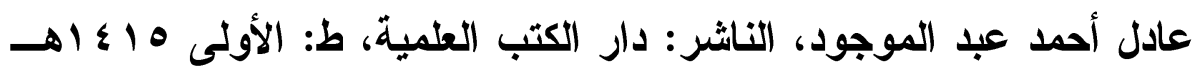

r ا. أصول أهل السنة والجماعة (بترقيم الشاملة آليا). r ا. . أضواء البيان في إيضاح القرآن بالقرآن لمحمد الأمين بن محمد المختار بن عبد القادر الجكني الثنقيطي، الناشر: دار الفكر للطباعة والنشر والتوزيع

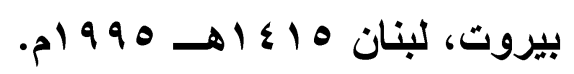

ع ا. الأعلام لخير الاين الزركلي، الناشر: دار العلم للملايين، ط: الخامسة عشر

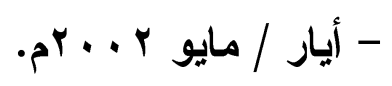

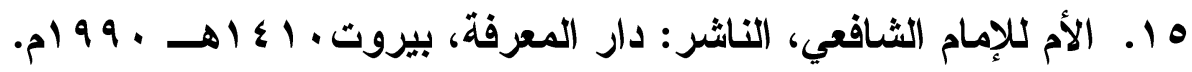
14. البحرين في صدر الإسلام: د/ عبد الرحمن العانى، ط: الدار العربية

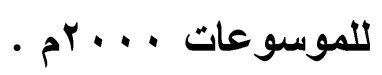

I V . بدائع الفوائد لابن قيم الجوزية، الناشر: دار الكتاب العربي، بيروث، لبنان. 11. تاج العروس من جواهر القاموس للزبياى، تحقيق: مجموعة من المحققين، الناشر: دار الهداية .

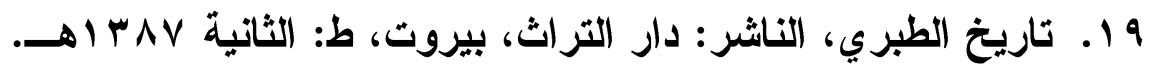
• r. التخليص الحبير لابن حجر، ط: شركة الطباعة الفتية. اY. تغليق التعليق على صحيح البخاري لابن حجر العسقلاتي، تحقيق: سعيد عبد الرحمن موسى القزقي، الناشر: المكتب الإسلامي، دار عمار، بيروت،

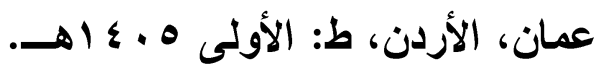
r r. تفسير ابن كثير (تفسير (القرآن العظير)، تحقيق: سامي بن محمد سلامة،

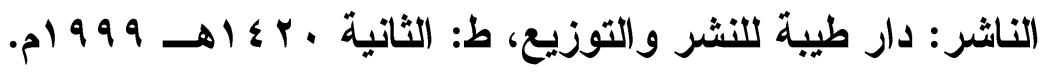


rr. تفسير الآلوسى (روح المعاني)، المطبعة المنيرية، القاهرة 900 ام. צ r. تفسير البغوي (معالم التنزيل في تفسير القرآن) للبغوي، تحقيق: عبدالرزاق المهاي، الناشر: دار إحياء التراث العربي، بيروت، ط: الأولى

\section{. $1 \leqslant r$.}

ه . تفسير الثعلبي (الكثف والبيان عن تفسير القرآن)، تحقيق: الإمام أبي محمد ابن عاشور، مراجعة وتدقيق: الأستاذ نظير الساعدي، الناشر: دار

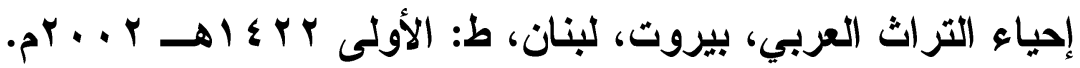

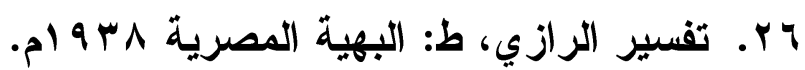
rV تفسير السعدي (تيسير الكريم الرحمن في تفسير كلام المنان) لعبد الرحمن ابن ناصر بن عبد الله السعدي، تحقيق: عبد الرحمن بن معلا اللويحق،

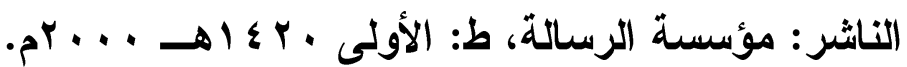
^r. . تفسير الشعراوي (الخواطر)، الناشر: مطابع أخبار اليوم. و r. تفسير الطبري (جامع البيان في تأويل القرآن)، تحقيق: أحمد محمد شاكر،

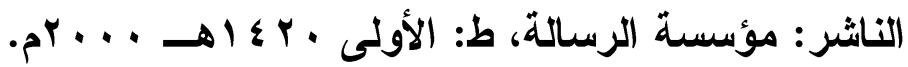

• r. . تفسير القرآن الكريم: محمد أحمد إسماعيل المقدم (بترقيم الثاملة آليا). اس. التفسير القرآني للقرآن لعبدالكريم يونس الخطيب، الناشر: دار الفكر

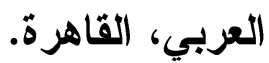

r r. تفسير القرطبى (الجامع لأحكام القرآن)، تحقيق: هثام سمير البخاري، ط:

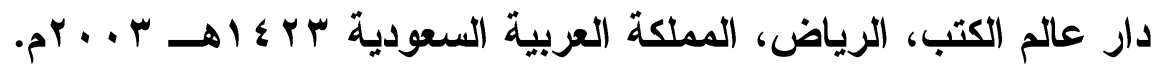
rr. التفسير الكبير (مفاتيح الغيب) للفخر الرازي، الناشر: دار إحياء التراث

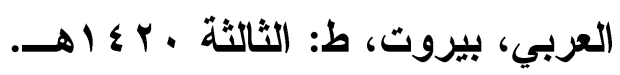

ع س. تفسير المراغي لأحمد بن مصطقى المراغي، الناشر: شركة مكتبة ومطبعة

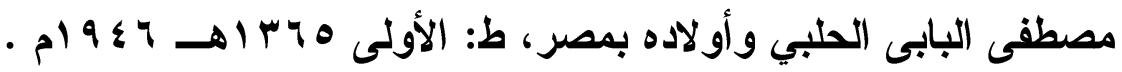




\section{د. قتحي محمود محمد عبد الرحمن}

ه r. تفسير حدائق الروح والريحان في روابي علوم القرآن للثيخ العلامة محمد الأمين ابن عبد الله الأرمي العلوي الهرري الثافعي، إثراف ومراجعة: الاكتور/ هاثم محمد علي بن حسين مهدي، الناشر: دار طوق النجاة،

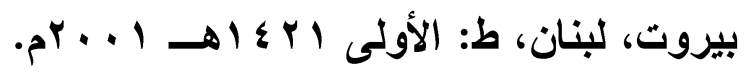

وس. تلبيس إبليس لجمال الاين أبو الفرج الجوزي، الناشر: دار الفكر للطباعة

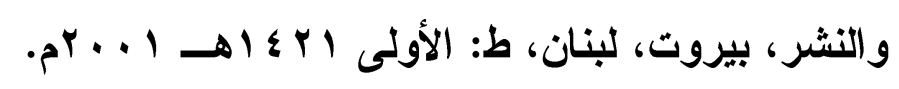

rV

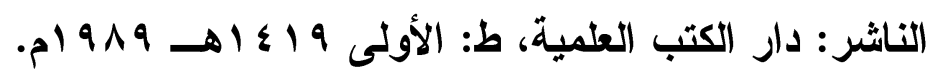

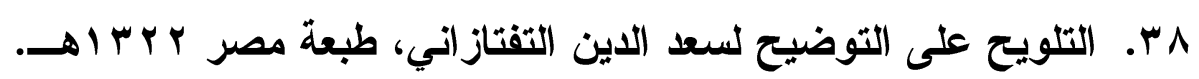
qr. التتبيه والرد على أهل الأهواء والبدع لأبى الحسين محمد المَّلطي، تحقيق: محمد زاهد بن الحسن الكوثري، الناشر : المكتبة الأزهرية للتراث، مصر. • ع. تهذيب اللغة للأزهري، تحقيق: محمد عوض مرعب، الناشر: دار إحياء

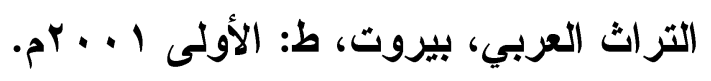

اء. تيسير التفسير للقرآن الكريم لمحمّ بن يوسف اطفيش، ط: عيسى البابى

$$
\text { الحلبى. }
$$

r ז. جامـع العلوم والحكم في شرح خمسين حديثا من جوامع الكلم لابن رجب الحنبلي، تحقيق: شعيب الأرناؤوط - إبراهيم باجس، الناشر: مؤسسة

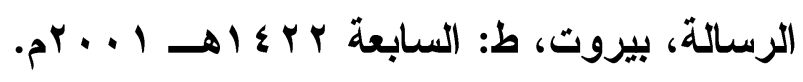

بـ الجموع البهية للعقيدة السلفية التي ذكرها العلامة الثنِقيطي في تفسيره أضواء البيان، جمع: أبو المنذر محمود بن محمد بن مصطفى بن عبداللطيف

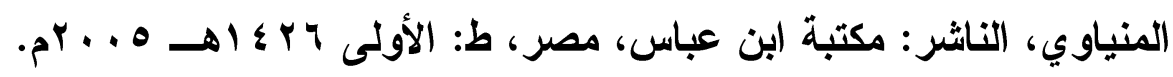
ع ء. حاشية الاسوقي على الثرح الكبير، الناشر: دار الفكر، بدون طبعة وبدون

تاريخ.

هـ ـ الحلية لأبى نعيم، ط: السعادة. 
צ ؛. الخوارج تاريخهم وآراؤهم الاعتقادية وموقف الإسلام منها رسالة ماجستير

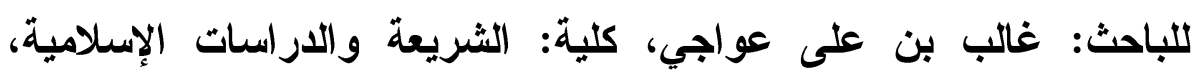
جامعة: الملك عبدالعزيز، مكة، السعودية. \&V V. الدر المختار بهامش حاثية (بن عابدين، الناشر: دار الفكر، بيروت، ط:

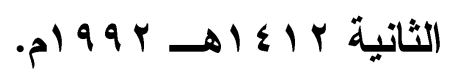

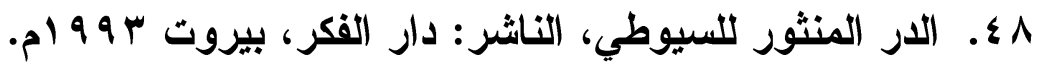
9ء. روائع البيان تفسير آيات الأحكام لمحمد علي الصابوني، طبع على نفقة: حسن عباس الشربتلي، الناشر: مكتبة الغزالي، دمشق، مؤسسة مناهل

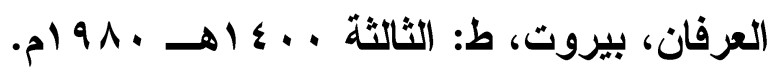

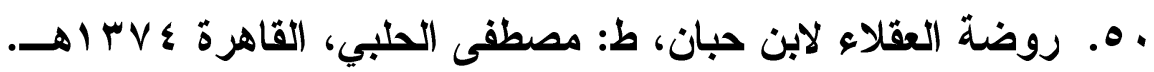
اه. زاد المعاد في هدى خير العباد لابن القيم الجوزية، الناشر: مؤسسة الرساية، بيروت، مكتبة المنار الإسلامية، الكويت، ط: السابعة والعشرون

$$
\text { . } 99 \leq \rightarrow 1 \leq 10
$$

ro. سنن ابن ماجه، تحقيق: محمد فؤاد عبد الباقي، الناشر: دار إحياء الكتب

$$
\text { به . سنن أبى داود، ط: فيصل عزت عيسى البابي الحلبي. }
$$

ع ه. سنن الارارقطن، حققه وضبط نصه وعلق عليه: شعيب الارنؤوط، حسن عبد المنعم شلبي، عبد اللطيف حرز الله، أحمد برهوم، الناشر: مؤسسة

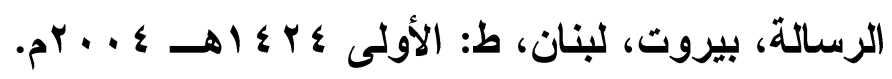$$
\text { هـ. سنن الارقطني، ط: دار المحاسن. }
$$

7ه. السنن الكبرى للبيهي، تحقيق: محمد عبد القادر عطا، الناشر: مكتبة دار

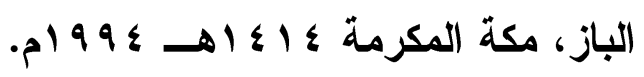

هV . شرح الأربعين النووية لابن دقيق العيد، الناشر: مؤسسة الريان، ط:

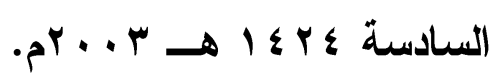


1ه. الثرح الكبير وحاشية الاسوقي، عيسى الحلبي، القاهرة. 9ه. شرح كتاب النيل وشفاء العليل لمحمّ بن يوسف اطفيش. • ج. شرح نهج البلاغة لابن ابي الحديد المعتزلي، تحقيق: محمد ابراهيم،

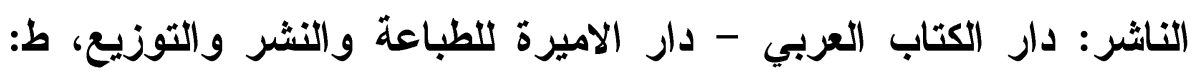

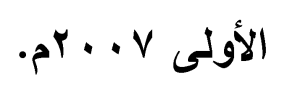

الـ صحيح البخاري (الجامع المســند الصحيح المختصر من أمور رسول الله -

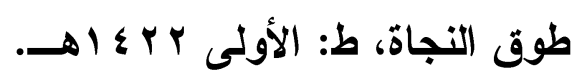

r ז.. صحيح مسلم (الجامع الصحيح المسمى صحيح مسلم)، الناشر: دار الجيل

$$
\text { بيروت ، دار الأفاق الجديدة، بيروت. }
$$

rا7. صحيح وضعيف سنن أبي داود: لمحمد ناصر الدين الألباني، مصدر الكتاب: برنامج منظومة التحقيقات الحديثية - المجاني - من إنتاج مركز نور

$$
\text { الإسلام لأبحاث القر آن والسنة بالإسكندرية. }
$$

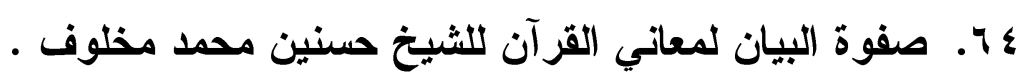

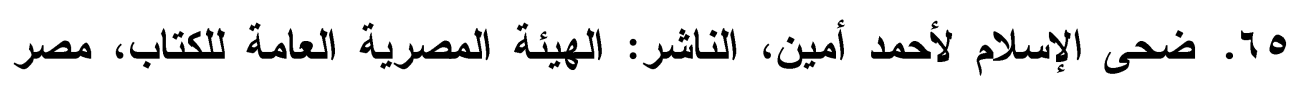
-p) $99 \mathrm{~V}$

דا. ضوابط التكفير عند أهل السنة والجماعة لعبد الله بن محمد القرني، المصدر : موقع مكتبة صيد الفوائد. VI. ظاهرة الإرجاء في الفكر الإسلامي (دكتوراة) لسفر بن عبد الرحمن

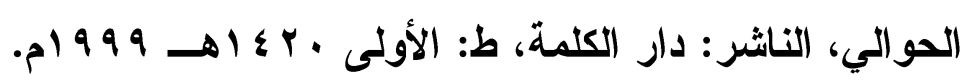
^ ד. فتح الباري لابن حجر العسقلاتي، رقم كتبه وأبوابه وأحاديثه: محمد فؤاد عبد الباقي، قام بإخراجه وصححه وأثرف على طبعه: محب الاين

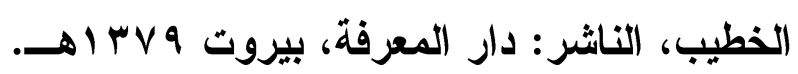


9. فتح العلي الحميد في شرح كتاب مفيد المستفيد في كفر تارك التوحيد لمدحت بن الحسن آل فراج، الناشر: دار الأخيار. • V. فتح القدير للشوكانى، الناشر: دار ابن كثير، دار الكلم الطيب، دمشت،

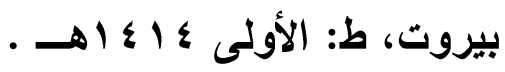
1. الفتح الكبير في ضم الزيادة إلى الجامع الصغير لجلال الدين السيوطي، تحقيق: يوسف النبهاني، ط: دار الفكر، بيروت، لبنان، ط: الأولى

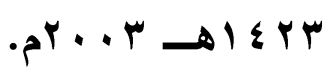

Vr. الفرق بين الفرق وبيان الفرقة الناجية لعبد القاهر البغدادي، الناشر: دار الآفاق الجديدة، بيروت، ط: الثانية 9VV أم. r. الفصل في الملل والأهواء والنحل لابن حزم الأدلسي، الناشر: مكتبة

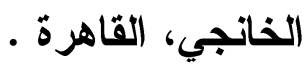

ع V. القاموس المحيط لمجد الدين الفيروزآبادى، تحقيق: مكتب تحقيق التراث في مؤسسة الرسالة، بإثراف: محمد نعيم العرقسُوسي، الناشر: مؤسسة

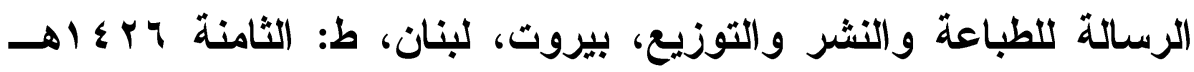

$$
\text { م. o }
$$

ه V. الكامل في التاريخ لابن الأثير، تحقيق: عمر عبد السلام تلمري، الناشر:

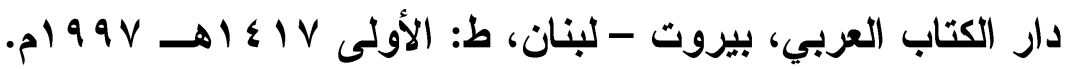
צ. الكامل في اللفة والأدب للمبرد، تحقيق: محمد أبو الفضل إبراهيم، الناشر:

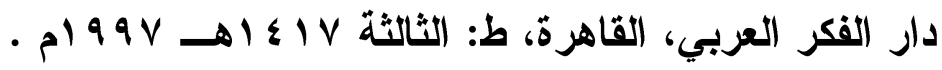
VV . Vتاب النيل وشفاء العليل لعبد العزيز الثميني الإباضي. N. VA كثف الأسرار عن أصول البزدوي لعبد العزيز البخاري، ط: دار الخلافة. 99. كثف الثبهات للثيخ محمد بن عبدالوهاب، الناشر: وزارة الثؤون الإسلامية والأوقاف والاعوة والإرشاد - المملكة العربية السعودية، ط:

\section{0}




\section{د. فتحي محمود محمد عبد الرحمز}

• ^. كشف المشكل من حديث الصحيحين للجوزي، تحقيق: علي حسين البواب،

$$
\text { الناشر: دار الوطن - الرياض. }
$$

ا ^. لسان العرب لابن منطور، الناشر: دار صادر، بيروت، ط: الثالثة

\&

r ^. لوامع الأنوار البهية لشمس الدين السفاريني، الناثر: مؤسسة الخافقين

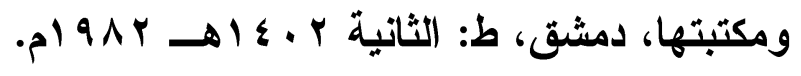

ץ ^. المبسوط للسرخسي، بيروث، ودار المعرفة بالأوفست عن طبعة القاهرة. ء.. مختار الصحاح للرازي، تحقيق: محمود خاطر، الناشر: مكتبة لبنان

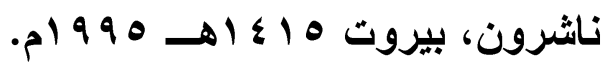

هـ. مختصر التحفة الاثني عشرية للألوسي، حققه وعلق حواثيه: محب الاين

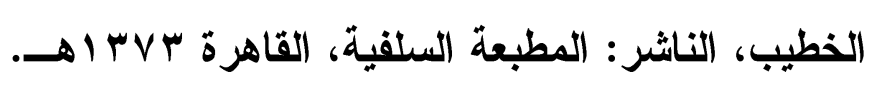

צ 1. وزارة الشئون الإسلامية والأوقاف والدعوة والإرشاد - المملكة العربية

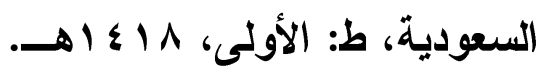

Av . المستدرك على الصحيحين للحاكم النيسابوري، تحقيق: مصطقى عبدالقادر

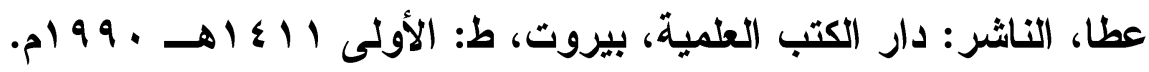
^^. مشارق الأنوار الوهاجة ومطالع الأسرار البهاجة في شرح سنن الإمام ابن ماجه لمحمد بن علي بن آدم بن موسى، الناشر: دار المغني، الرياض،

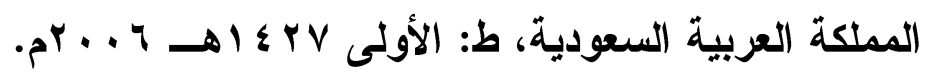

ه. المصنّف لأبى بكر أحمد بن عبد اللّه بن موسى الكندي السمدي الإباضي. •9. معالم السنن للخطابي، ط: المطبعة العلمية - حلب، ط: الأولى اهب اهله . 9 pr 19. معاني القراعات للأزهري، الناشر: مركز البحوث في كلية الآداب، جامعة

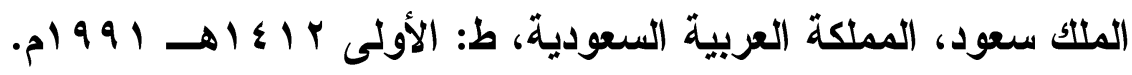

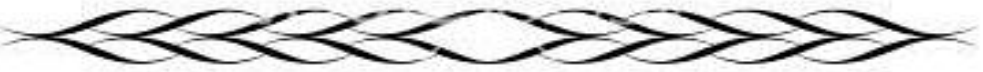


r9. المعتبر لأبى سعيد الإباضي، الناشر: وزارة التراث القومي والثقافة. به. معجم الشعراء العرب، تم جمعه من الموسوعة الثعرية (بترقيم الثاملة آليا)

؟ 9. ه 9. مقالات الإسلاميين واختلاف المصلين لأبى الحسن الأشعري، تحقيق: نعيم

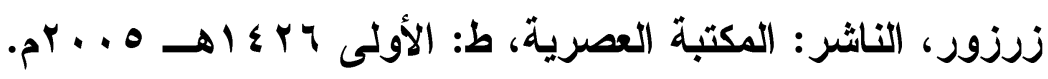
9. المكاسب للشيخ الأصاري، تحقيق: مجمع الفكر الإسلامي، لجنة تحقيق

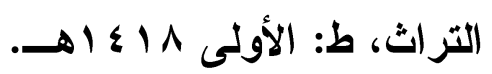
9V V الملل والنحل للشهرستاني، تحقيق: محمد سيد كيلاني، الناشر: دار

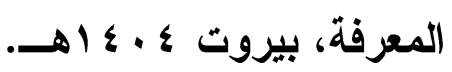

19. منهاج السنة النبوية في نقض كلام الثيعة القدرية لشيخ الإسلام ابن تيمية، تحقيق: محمد رشاد سالم، الناشر: جامعة الإمام محمد بن سعود

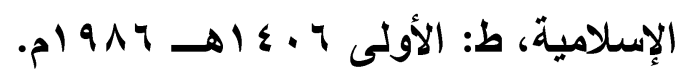

9 9. الموسوعة العقدية - الدرر السنية (بترقيم الثاملة آليا).

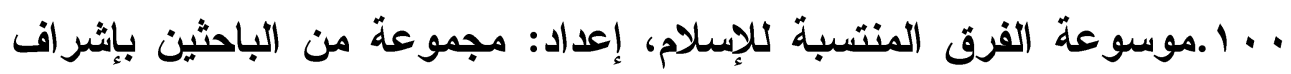
الشيخ عَّوي بن عبد القادر السقاف (بترقيم الشاملة آليا)، الناشر: موقع

$$
\text { الارر السنية على الإنترنت. }
$$

1 ـ.الموسوعة الفقهية الكويتية، صادر عن: وزارة الأوقاف والشئون

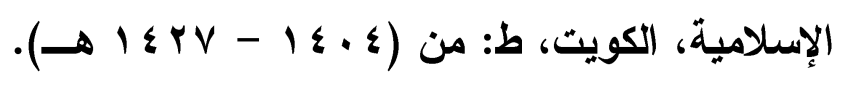

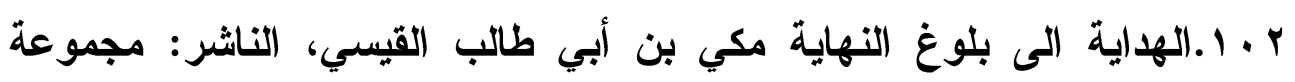

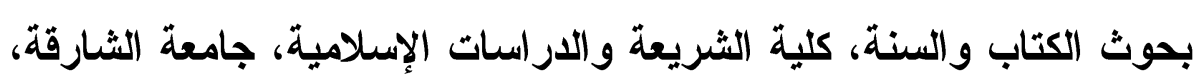

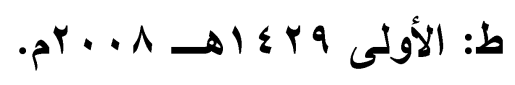

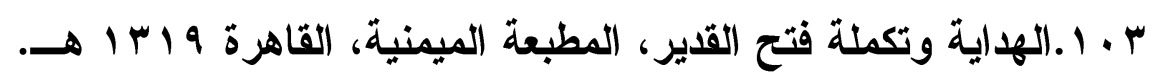


ع ـ ا.الوجيز في عقيدة السلف الصالح (أهل السنة والجماعة) لعبد الله بن عبد الحميد الأثري، مراجعة وتقديم: صالح بن عبد العزيز آل الثيخ، الناشر: وزارة الثؤون الإسلامية والأوقاف والدعوة والإرشاد، المملكة العربية

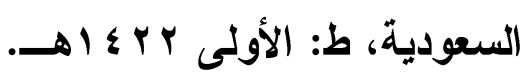
هـ ـ الأوجيز في عقيدة السلف الصالح أهل السنة والجماعة. 7 ا ـ الولاء والبراء في الإسلام من مفاهيم عقيدة السلف لمحمد بن سعيد بن سالم القحطاني، تقديم: فضيلة الثيخ عبد الرزاق عفيفي، الناشر: دار طيبة، الرياض، المملكة العربية السعودية، ط: الأولى.

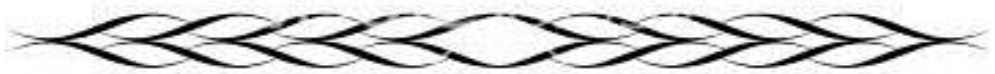




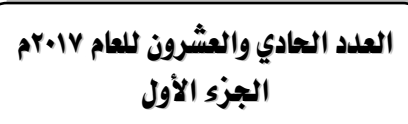

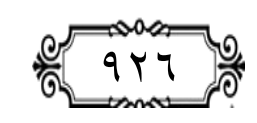

حولية كلية اللفة العربية بجرجا مجلة علمية محكمة

فهرس الموضوعات

\begin{tabular}{|c|c|c|}
\hline |لصفم & الموضــــــ & P \\
\hline$\Lambda \leqslant 1$ & الاقدهمة & 1 \\
\hline Aะr & المبحث الأول : التعريف بالمطاتحات الهاردة في عنوان البحث & r \\
\hline A & أولا: هفهوم التقية في اللغة والاصطلاح: & $r$ \\
\hline ᄉos & ثانيًا: التهريف بالخوارج & $\varepsilon$ \\
\hline 107 & ثالثً: تعريف أهل السنة & ○ \\
\hline 109 & ه الثاني: أراء وأفكار الخوارج في التقيـة & 9 \\
\hline AYV & المبحث الثالث: هوقف أهل السنة واراهم فى التقيهة & V \\
\hline $91 \varepsilon$ & الخـاتمسة & $\Lambda$ \\
\hline 917 & قائمة المسادر والمراجع & 9 \\
\hline ary & فهرس الموضوعات & 1 . \\
\hline
\end{tabular}

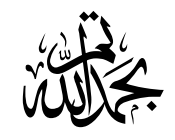

